\title{
Development of Defense Signaling Pathways Against Bacterial Blight Disease in Rice Using Genome-Wide Transcriptome Data
}

\author{
Ki Hong Jung ${ }^{1}$, Muho Han², Van Ngoc Tuyet Nguyen ${ }^{1}$, Youngchul Yoo ${ }^{2}$, Minh-Phuong Nguyen ${ }^{2}$, Chanhui Lee ${ }^{3}$, \\ Sang-Won Lee ${ }^{1} \&$ Jong-Seong Jeon ${ }^{2}$ \\ ${ }^{1}$ Department of Plant Molecular Systems Biotechnology \& Crop Biotech Institute, Kyung Hee University, \\ Republic of Korea \\ ${ }^{2}$ Graduate School of Biotechnology, Kyung Hee University, Republic of Korea \\ ${ }^{3}$ Department of Plant Environmental and New Resources, Kyung Hee University, Republic of Korea \\ Correspondence: Ki Hong Jung, Department of Plant Molecular Systems Biotechnology \& Crop Biotech Institute, \\ Kyung Hee University, Republic of Korea. E-mail: khjung2010@khu.ac.kr
}

Received: April 15, 2014 Accepted: April 24, 2014 Online Published: June 15, 2014

doi:10.5539/jas.v6n7p48 URL: http://dx.doi.org/10.5539/jas.v6n7p48

\begin{abstract}
Bacterial blight (BB) disease caused by Xanthomonas oryzae pv. oryzae (Xoo) drives severe yield and quality losses in rice (Oryza sativa Xa1, Xa3/Xa26, xa5, xa13, Xa21, and Xa27). Here we employ a transcriptomics approach to elucidate the Xa21-, NH1- (NPR1 homolog 1) (NH1)-, and NRR- (negative regulator of disease resistance) mediated defense response to Xoo. Among the candidate genes, we focused on 288 genes showing significant change in at least two of the above comparisons to support the association with an enhanced defense response. Gene Ontology enrichment analysis for this gene list revealed that response to biotic stimulus was 25.0-fold more enriched compared to the control, well qualifying the candidate genes for enhanced resistant response. The biotic stress overview installed in the MapMan toolkit was used to identify diverse components consisting of defense signaling pathways such as genes involved in disease resistance, redox, signaling, regulation of transcription, pathogenesis-related functions, secondary metabolism, and protein degradation. Of these, we validated the expression patterns of genes related to regulation of transcription and pathogenesis-related functions and suggest a functional network model for WRKY transcription factors mediating defense signaling pathways against Xoo. We expect that our analysis will contribute to increasing the depth of knowledge on the molecular mechanism for enhanced disease resistance against bacterial blight disease in rice.
\end{abstract}

Keywords: bacterial blight disease, disease resistance, functional gene network, microarray, rice

\section{Introduction}

Rice (Oryza sativa L.) is an important staple food, feeding more than half of the global population, and is a model for other monocotyledonous species, including most cereal crops. Rice production, however, is severely restricted by biotic stresses, such as pathogenic bacteria, fungi, and viruses. Bacterial blight (BB), a disease which often provokes severe losses of rice grain, is caused by Xanthomonas oryzae pv. oryzae (Xoo) (Nino-Liu, Ronald, \& Bogdanove, 2006). Six of the 34 major resistance genes for BB have been cloned and characterized at the molecular level (Lee et al., 2011). Of these, Xa21 encodes a leucine-rich repeat (LRR) receptor kinase which is positively involved in the defense response (Song et al., 1995). In addition, overexpression of non-expressor of pathogenesis related gene 1 (NPR1) homolog 1 (NH1) in rice results in BB resistance and potentiates a benzothiadiazole (BTH)-induced lesion mimic or cell death phenotype (Yuan et al., 2007). Overexpression of a negative regulator of disease resistance $(N R R)$ which interacts with $\mathrm{NH} 1$ in rice affects Xa21-mediated resistance by enhancing susceptibility to BB (Yuan et al., 2007). Recently, we developed a stress interactome mediated by $\mathrm{Xa} 21, \mathrm{NH} 1$, and NRR, as a hypothetical model to study the molecular mechanism of BB resistance (Seo et al., 2011).

An integrated omics analysis is one of the most powerful methods to unveil a functional network of molecular pathways strongly associated with the candidate genes. Network analysis is dependent on integrated omics analysis. In rice, there are four web tools for this purpose: RiceNet (http://www.functionalnet.org/ricenet/), the Rice Interaction Viewer (http://bar.utoronto.ca/interactions/cgi-bin/rice_interactions_viewer.cgi), the Predicted 
Rice Interactome Network (PRIN, http://bis.zju.edu.cn/prin/), and Planet (http://aranet.mpimp-golm.mpg.de/ricenet) (Gu, Zhu, Jiao, Meng, \& Chen, 2011; Lee et al., 2011; Mutwil et al., 2011). Of these, RiceNet was successfully used to identify three novel regulators which control resistance mediated by Xa21: Regulator of XA21-Mediated Immunity 1 (ROX1), ROX2, and ROX3 (Lee et al., 2011).

Oligonucleotide microarray analysis provides a global view of transcriptional regulation mediated by a key gene associated with a significant biological process. More than 4,000 rice oligonucleotide microarray datasets, including gene expression profiles of rice responses to Xoo infection, are available in the NCBI gene expression omnibus public microarray database (GEO, http://www.ncbi.nlm.nih.gov/geo/) (Barrett et al., 2011; Jung, Jeon, $\&$ An, 2011). These data serve as a reference to study the rice defense response against a selected pathogen. Recently, we also generated genome-wide microarray analyses of Xa21-TP309 vs. TP309, NH1ox vs. LiaoGeng (LG), and NRRox vs. $L G$ after Xoo inoculation. These data were used to evaluate the XA21 interactome. However, we did not provide a detailed analysis of the transcriptome data.

Genome-wide transcriptome data yield a large amount of candidate genes, ranging from several hundreds to thousands, which are differentially expressed under the treatment condition. This feature of the transcriptome data limits further application. Gene ontology (GO) analysis is used to categorize biological meanings of candidate genes from genome-wide transcriptome data using microarray or RNA-seq technology. GO data are provided in three principle categories: biological process, cellular component and molecular function (Jung et al. 2008). MapMan is also useful as a user-driven categorization tool for displaying genomic data sets on diagrams of metabolic pathways and other biological processes (Jung \& An, 2012; Peltier, Ytterberg, Sun, \& van Wijk, 2004).

Here we analyzed the rice transcriptome to identify genes associated with resistance to Xoo infection. Three rice lines with different levels of $\mathrm{BB}$ resistance were compared to the susceptible controls through transcriptome analysis: the Xa21 line carrying functional Xa21 from wild rice species in TP309 (Xa21-TP309) and NHloverexpressing line (NH1ox) both had enhanced resistance phenotypes to BB, whereas the NRR overexpressing line (NRRox) had enhanced susceptibility. We identified 338, and 610 genes which were significantly upregulated in Xa21 and NH1ox, respectively, compared to the susceptible controls. In addition, we identified 186 genes which were significantly downregulated in the NRRox line compared to the susceptible control. Among them, we focused on 288 genes showing significant change in at least two of the above comparisons for further scrutiny by GO enrichment analysis, MapMan analysis, and functional gene network.

\section{Materials and Methods}

\subsection{Plant Growth}

Seeds from NRRox, NH1ox, LG, TP309, and Xa21-TP309 (I106) rice plants were germinated by placing them in water for 2 days (d). Seeds were then planted in clay soil and maintained in a greenhouse. After 8 weeks, the plants were moved to a growth chamber with controlled temperature and humidity. The plants were adapted for $2 \mathrm{~d}$ and then inoculated on the leaf with Xoo isolate $P X O 99$ by the clipping method. $L G$ has the same genetic background as NRRox and NH1ox, and TP309 has the same background as Xa21. For the microarray experiment, NRRox was compared to $L G$ (WT), NH1ox was compared to $L G$ (WT), and Xa21 was compared to TP309 (WT). Eight-week-old leaf tissues were collected $1 \mathrm{~d}$ after inoculation with Xoo for the NH1ox and NRRox lines, and 2 $\mathrm{d}$ after inoculation with $\mathrm{Xoo}$ for the Xa21 line. We prepared at least two replicates for each sample and each replicate contained at least five pooled leaves.

\subsection{RNA Extraction and Microarray Experiment}

At least $500 \mu \mathrm{g}$ total RNA was isolated using TRIZOL reagent (Invitrogen), followed by DNaseI-treatment for 15 minutes, purification with an RNeasy Midi Kit (Qiagen), and enrichment for poly-A RNA using the Oligotex mRNA Kit (Qiagen). All steps were performed according to the manufacturer's instructions. All hybridizations were conducted at the ArrayCore Microarray Facility at the University of California, Davis (http://array.ucdavis.edu/home/) as previously described (Jung et al., 2008).

\subsection{Microarray Data Processing and Analysis}

Spot intensities were quantified using Axon GenePix Pro 4.0 image analysis software. GenePix Pro 4.0 result data files (.gpr files) were generated using high PMT and low PMT settings. For high PMT, the data were normalized using the Lowess normalization method in the LMGene Package in R (Lu et al., 2008). The LMGene method developed by Rocke (2004) was also used to identify differentially expressed genes. "S" was used to indicate a susceptible response, "ES" an enhanced-susceptible response, and "R" a resistant response. False discovery rates (FDRs) and fold changes of NRRox (ES) compared to $L G(\mathrm{~S}), N H 1$ ox (R) compared to $L G$ (S), 
and $X a 21$ (R) compared to TP309 (S) were generated. Data with p-values $<0.05$ by a t-test and $>1.5$-fold change (i.e. $\log _{2} \mathrm{R} / \mathrm{S} \geq 0.6$ or $\log _{2} \mathrm{SS} / \mathrm{S} \leq-0.6$ ) in at least two comparisons are presented in Table S1. These microarray data were deposited in the NCBI GEO with Accession No. GSE22112. Other data were collected from the NCBI gene expression omnibus (GEO, http://www.ncbi.nlm.nih.gov/geo/). The marray R package in Bioconductor was used to normalize Agilent 22K array data (GSE5906 and GSE32635), followed by calculation of the average of the $\log _{2}$ fold changes for each comparison (Wang, Nygaard, Smith-Sorensen, Hovig, \& Myklebost, 2002). To process Agilent 44K array data (GSE7567), median signal intensities of Cy3 were converted to $\log _{2} \operatorname{median}$ intensities, then normalized using the quantile normalization method (Bolstad et al., 2003).

\subsection{Gene Ontology (GO) Enrichment Analysis}

The GO terms and assignments for rice genes were downloaded from the Gramene database (http://www.gramene.org/) (Youens-Clark et al., 2011). A hypergeometric distribution was then used to calculate the $p$ value for GO enrichment analysis installed in the Rice Oligonucleotide Array Database (ROAD, http://www.ricearray.org/analysis/go_enrichment.shtml) (Cao, Jung, Choi, Hwang, \& Ronald, 2012). We uploaded locus IDs of 288 genes in a toolbox for the GO enrichment analysis in the biological process category and identified 333 GO terms assigned to 160 genes. Significant GO terms in the biological process category were identified based on a more than 2-fold enrichment value with less than 0.05 hypergeometric p-values. Eleven GO terms in the biological process category were identified (Figure 1, Tables S2 and S3).


Figure 1. Gene Ontology enrichment analysis of 288 genes associated with enhanced bacterial blight defense. The

Gene Ontology (GO) enrichment analysis tool installed in the rice oligonucleotide array database (ROAD, http://www.ricearray.org/) was used to identify GO terms enriched in the selected 288 genes. The x-axis indicates the name of the GO term, and the y-axis indicates the GO enrichment value in the lower panel or number of each $\mathrm{GO}$ term in the upper panel. The GO enrichment value and number of each GO term are represented as numeric values in this figure. Detailed gene information of enriched GO terms in this analysis is shown in Tables S2 and S3

\subsection{MapMan Analysis}

A total of 36 MapMan BINs were generated for the Rice MapMan classification; these were extended in a hierarchical manner into subBINs (Urbanczyk-Wochniak et al., 2006; Usadel et al., 2005). We generated a dataset using locus IDs in RGAP version 7 annotation, and a fixed numeric value, 1, indicating 288 genes associated with multiple enhanced defense responses. The data were uploaded to the biotic stress overview which we had recently introduced and installed in the MapMan toolkit (Jung \& An, 2012). The image data of the biotic stress overview was used for Figure 2. Detailed information is shown in Table S4. 




Figure 2. MapMan analysis in biotic stress overview of genes associated with enhanced bacterial blight defense. The biotic stress overview installed in the MapMan toolkit was integrated with 288 genes associated with enhanced bacterial blight defense. In the overview, 95 elements were identified. Red squares indicate genes associated with enhanced bacterial blight defense in this overview. Detailed information on the MapMan overviews is provided in Table S4

\subsection{Generation of Heatmap Using Microarray Data}

We used MeV software to generate heatmap expression patterns using the fold data in Table S4 as an input (tap-delimited txt format) (Figure 3).

\subsection{RT-PCR Analysis}

We isolated 20-50 $\mu \mathrm{g}$ of total RNAs extracted from 8-week-old leaf before inoculation, after $1 \mathrm{~d}$ and $2 \mathrm{~d} \mathrm{Xoo}$ (PXO99) inoculation using Trizol reagent, and then treated it with DNaseI for $15 \mathrm{~min}$ before purifying it with an RNeasy Midi Kit (Qiagen, USA). Quantities of total RNA and mRNA were determined by measuring $A_{260}$ and $A_{280}$ with a Nanodrop ND-1000. The level of protein contamination in the RNA was estimated based on the $A_{260}$ to $A_{280}$ ratio. Only RNA samples with ratios of 2.0 to 2.2 were used for these experiments. cDNA was synthesized from $2 \mu \mathrm{g}$ of total RNA using Moloney murine leukemia virus reverse transcriptase (Promega, USA) in a reaction buffer. PCR was performed in a $30 \mu \mathrm{L}$ solution containing a $1-\mu \mathrm{L}$ aliquot of the cDNA reaction, 0.2 $\mu \mathrm{M}$ gene-specific primers, $10 \mathrm{mM}$ dNTPs, 1 unit of ExTaq DNA polymerase (Takara, Japan), and reaction buffer. The reaction included an initial 5 -minute denaturation at $94{ }^{\circ} \mathrm{C}$, followed by 21 to 40 cycles of PCR $\left(94{ }^{\circ} \mathrm{C}\right.$ for $45 \mathrm{sec}, 60{ }^{\circ} \mathrm{C}$ for $45 \mathrm{sec}$, and $72{ }^{\circ} \mathrm{C}$ for 1 minute), and a final 10 minutes at $72{ }^{\circ} \mathrm{C}$. The balance of cDNA synthesis was estimated by RT-PCR using rice Ubiquitin 5 (OsUbi5/Os01g22490 with forward primer 5'-GCACAAGCACAAGAAGGTGA-3' and reverse primer 5'-GCCTGCTGGTTGTAGACGTA-3'), and rice Ubiquitin 1 (OsUbil/Os03g13170; forward primer 5'-TGAAGACCCTGACTGGGAAG-3' and reverse primer 5'-CACGGTTCAACAACATCCAG-3'). We then analyzed expression patterns for 18 genes belonging to RNA category and pathogen-related protein group in Figure 3. RT-PCR was conducted as described previously (Jung et al., 2006). Primer sequences are listed in Table S5. 

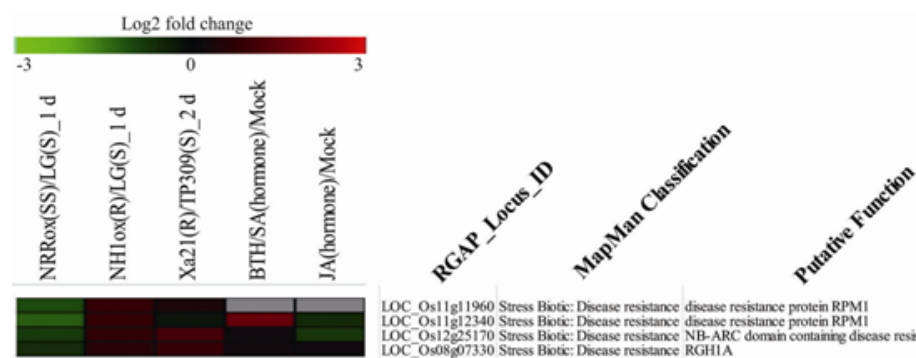

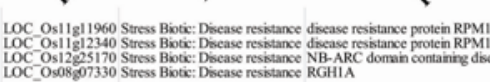


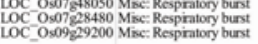


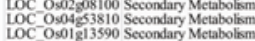



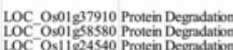

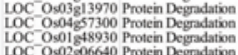





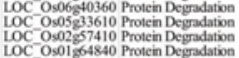



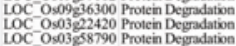

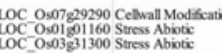

NRR $\mathrm{NH1}, \mathrm{N}$
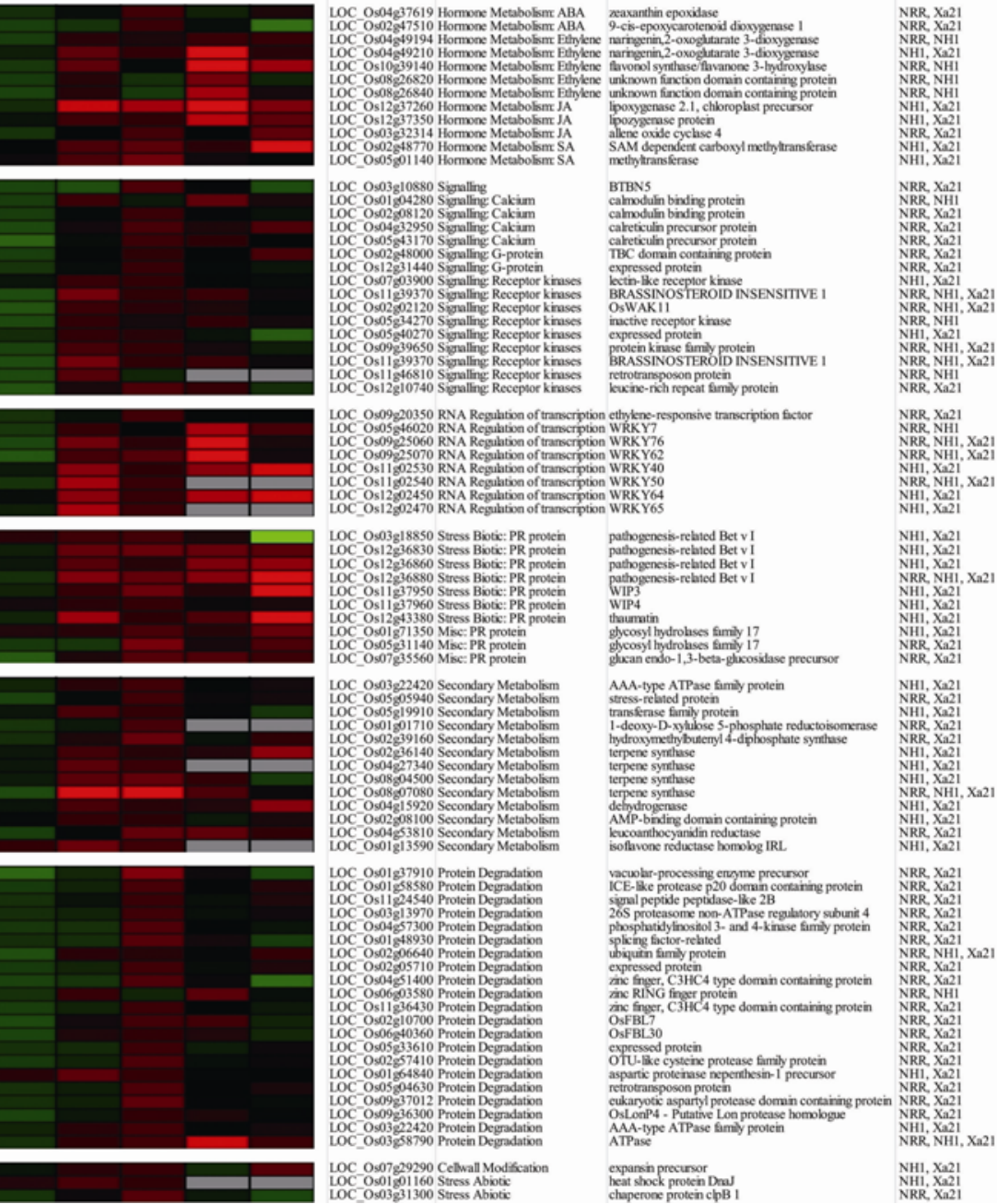

Figure 3. Expression patterns of 95 genes associated with enhanced bacterial blight defense. Two comparisons of enhanced resistance and susceptibility strains and one comparison of enhanced-susceptibility and susceptible strains identified 95 genes in the MapMan biotic stress overview associated with defense response, oxidative burst, protein phosphorylation, transcriptional regulation, hormone signaling, and pathogenesis. In addition, the expression patterns of these genes in response to hormones such as SA/BTH and JA were used to generate a heatmap. Functional groups are assigned according to the order of each defense process after pathogen recognition. Green color indicates downregulation in enhanced resistance or enhanced-susceptible lines after Xoo inoculation or treatment with phytohormones, and red indicates upregulation. The detailed experimental conditions are provided in Table 1 and microarray data are provided in Table S4 


\section{Results and Discussion}

\subsection{Identification of Rice Genes Differentially Expressed in Response to Xoo Infection}

To identify rice genes associated with response to Xoo infection, we used genome-wide microarray analyses of Xa21-TP309 vs. TP309 after $2 \mathrm{~d}$ of Xoo inoculation, NH1ox vs. LG after 1 day of Xoo inoculation, and NRRox vs. $L G$ after 1 day of Xoo inoculation. In these transcriptome analyses (GSE22112), the TP309 line (susceptible to $X o o$ ) was used as a control for the TP309 line that carried a functional Xa21 gene. $L G$ was susceptible to Xoo, and served as a control for both the NHIox line, which had enhanced resistance, and the NRRox line, which had enhanced susceptibility in the $L G$ background. Four biological replicates were used to compare NHIox and NRRox to $L G$, and two replicates were used to compare Xa21 to TP309. Compared to the controls, upregulated genes in the resistant lines (Xa21 and NH1ox) or downregulated genes in the enhanced susceptibility line (NRRox) were candidates for enhanced defense response genes against Xoo challenge in rice. A total of 610 genes in Xa21 and 338 genes in NH1ox were upregulated by more than 1.7-fold $\left(\log _{2} 0.8\right)$, based on a p-value of $<0.05$ using a t-test, compared to the susceptible controls (Table S1). In NRRox, 186 genes were significantly downregulated compared to the susceptible control (Table S1).

Hormones such as salicylic acid (SA, GSE7567) and jasmonic acid (JA, GSE32635) are also involved in the plant disease response (Table 1) (Desaki et al., 2006). BTH is a functional analog of SA and protects plants from diseases by activating the SA signaling pathway (Shimono et al., 2007). The molecular mechanisms underlying BTH-induced disease resistance, which were elucidated by transcriptome analysis (GSE7567), were used to demonstrate that OsWRKY45 plays a crucial role in the BTH-inducible defense program in rice (Shimono et al., 2007). To investigate the induction of rice defense responses by JA, transcriptome analyses (GSE32635) were performed. The gene expression patterns in response to hormones were used as reference data to evaluate the gene expression patterns associated with enhanced Xoo defense identified in our transcriptome analysis. The overall scheme of our analysis is presented in Figure 4.

As we were more interested in the enhanced defense responses against a broad range of Xoo isolates, we identified 288 genes showing significant differential expression patterns in at least two of the following comparisons: upregulation in $\log _{2}$ NH1ox/LG $1 \mathrm{~d}$ after Xoo inoculation, upregulation in $\log _{2}$ Xa21/TO309 $2 \mathrm{~d}$ after Xoo inoculation, and downregulation in $\log _{2}$ NRRox/LG $1 \mathrm{~d}$ after Xoo inoculation (Figure 4, Table S1). These genes were used for further analyses. 


\section{Genome-wide transcriptome analyses for enhanced defense responses against $X O O$}

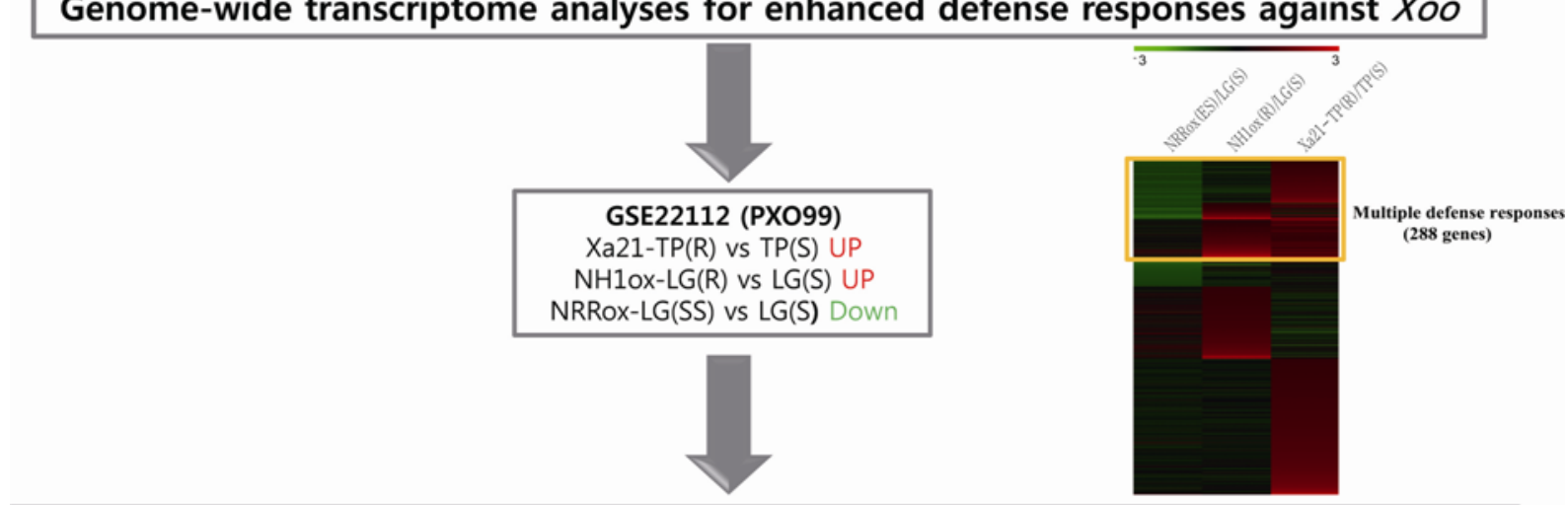

Identify candidate genes associated with multiple enhanced disease resistance against Xoo challenge (less than $0.1 \mathrm{t}$-test $\mathrm{p}$-value and more than 1.5 fold change)

Identify candidate genes enriched in biological progress $\mathrm{GO}$ terms associated with defense response Identify candidate genes for signaling pathway in biotic stress overview installed in MapMan tool (Disease resistance, respiratory burst, phosphorylation cascades, regulation of transcription, hormone metabolism, and pathogenesis relating proteins)

\section{Propose probabilistic functional gene network mediated by key defense genes against $\mathrm{X} O \mathrm{O}$ attack}

Figure 4. Overall scheme to develop a functional gene network for enhanced bacterial blight defense response in rice

\subsection{Identification of Biological Processes Associated With Broad Spectrum Resistance}

Recently, we developed a GO enrichment tool to identify the biological meaning of a selected gene list from high-throughput data analysis (Cao et al., 2012). In this tool, p-values are used to support enriched GO terms. The fold enrichment value is the ratio of the queried number of selected GO terms over the expected number (Jung et al., 2008). By applying GO enrichment analysis of the 288 genes found to be involved in the response to a broad range of pathogens, we identified eleven GO terms which were highly overrepresented in the gene list with a smaller than $0.01 \mathrm{p}$-value and a greater than 2 -fold increased enrichment value. Specifically, response to biotic stimulus was 25.0 -fold more enriched than the standard; chitin catabolic process, 12.8; regulation of nitrogen utilization, 11.9; tricarboxylic acid cycle, 10.8; lipid biosynthetic process, 7.1; steroid biosynthetic process, 6.9; cellular metabolic process, 6.3; glycolysis, 4.8; metabolic process, 2.5; transport, 2.3; and defense response, 2.3 (Figure 1, Table S2). The gene list belonging to these GO terms is shown in Table S3.

Of these GO terms, response to biotic stimulus showed the highest GO fold enrichment, and the features of genes selected in our analysis were well described by the enrichment of defense response and chitin catabolic process together with response to biotic stimulus GO terms. Close interplay between the plant immune system and plant steroids supported the roles of steroid biosynthetic processes in pathogen responses of rice (Belkhadir et al., 2012). Metabolic process is the most abundant GO term associated with response to a broad range of pathogens. The functions of four of these genes belonging to metabolic process have been identified: LOC_Os02g08100 encoding 4-Coumarate:coenzyme A ligase regulates of a broad range of biological events over the course of rice growth and development (Goodstein et al., 2012); LOC_Os03g09250 encoding myo-inositol 3-phosphate synthase 1, seed phytic acid content (Long et al., 2008); LOC_Os05g31140 encoding $\beta$-glucanase, blast resistance (Shimono et al., 2012); and LOC_Os08g03290 encoding cytosolic glyceraldehyde-3-phosphate dehydrogenase GAPDH protein 3, salinity tolerance (Shimono et al., 2007). Of these, $\beta$-glucanase was the only gene known so far to be related to pathogen responses. The contribution of glucosinolate transport to Arabidopsis defense responses, and depression of auxin transport capacity of infected Arabidopsis plants by A. brassicicola supported the significance of the transport GO term in the pathogen response of rice (Ellerbrock, Kim, \& Jander, 2007; Qi et al., 2012). Among rice genes belonging to the transport 
GO term, rice phosphate ( $\mathrm{Pi}$ ) transporter, OsPht1;1, is known to function in Pi uptake and translocation in rice under Pi-replete conditions (Sun et al., 2012), but its role in pathogen responses has not yet been analyzed. In summary, GO enrichment analysis effectively suggested the primary candidate genes for an enhanced defense response against $\mathrm{Xoo}$.

\subsection{Identification of MapMan Terms in Biotic Stress Overview With Response to Xoo Infection}

The biotic stress overview installed in the MapMan tool is useful to identify major elements in signaling pathways for defense response. We uploaded 288 genes to the MapMan tool and identified 95 genes in the biotic stress overview (Figure 2). The primary step is recognition of pathogen attack by $\mathrm{R}$ genes related to the defense response, such as pattern recognition receptors (PRRs) located at the plasma membrane (Boller \& Felix, 2009; Dardick \& Ronald, 2006; Desclos-Theveniau et al., 2012; Lee et al., 2009; Tena, Boudsocq, \& Sheen, 2011). Next is an oxidative burst including redox reactions and miscellaneous functions for an early hypersensitive response, hormone metabolism to modulate the defense response, signal transduction by phosphorylation, transcriptional regulation by transcription factors, and defense response by pathogenesis-related (PR) protein genes, genes relating to secondary metabolism and protein degradation (Delteil, Zhang, Lessard, \& Morel, 2010). Figure 3 shows the differential expression patterns of these genes in two enhanced resistance lines and an enhanced susceptibility line after Xoo inoculation, and after treatment with BTH and JA, compared to controls. Four genes were related to the defense response, 7 to the oxidative burst, 12 to hormone metabolism, 18 to phosphorylation cascades, 8 to transcriptional regulation, 10 to PR genes, 12 to secondary metabolism, 21 to protein degradation, and 3 to other functions (Figure 3; Table S4).

\subsection{Defense Response}

Among the defense response genes, we identified four genes belonging to the nucleotide-binding site (NBS)-LRR family. Two of these genes (Os11g11960 and Os11g12340) encode resistance to Pseudomonas syringae pv. maculicola 1 (RPM1) homologous proteins, one (Os12g25170) encodes an NBS-LRR protein, and one $(O s 08 g 07330)$ encodes resistance gene homolog 1a. Defense response is the most obvious functional group related to enhance $\mathrm{BB}$ resistance.

The NBS-LRR genes are particularly important for enhanced defense responses to BB (Bryan et al., 2000; Jeung et al., 2007; Lin et al., 2008; Okuyama et al., 2011; Yoshimura et al., 1998). Os12g25170 was upregulated in the NH1ox and Xa21 lines and downregulated in the NRRox line. Os1 1g11960 and Os1 Ig12340 encoding the RPM1 homolog were upregulated in the NHIox line and downregulated in the NRRox line (Figure 3). Arabidopsis RPM1 (At3g07040) is a disease resistance protein that specifically recognizes the AvrRpm1 type III effector, a virulence protein from Pseudomonas syringae, and protects the plant from the pathogen (Grant et al., 2000). This gene interacts with RPM1-interacting protein 4 (RIN4) and triggers plant resistance when RIN4 is phosphorylated by AvrRpm1 (Mackey, Holt, Wiig, \& Dangl, 2002). We expect that rice RPM1 homologs have similar roles to Arabidopsis RPM1 in the disease resistance response. Four genes described in this section belonged to different classes of the NBS-LRR protein family, suggesting that there might be diverse routes mediated by NBS-LRR for enhanced defense against BB.

\subsection{Respiratory Burst}

Among the respiratory burst genes, we identified seven genes associated with redox response and miscellaneous functions. Among them, Os02g43360 encoding cytochrome b5-like heme protein, Os $10 g 28200$ encoding NAD dependent epimerase, and Os12g08810 encoding vacuolar transporter chaperone 2 (VTC2) were relating to redox reactions. OsO7g37730 and $O s 09 g 29200$ encoding glutathione S-transferase (GST), and $O s 07 g 48020$ and Os0748050 encoding peroxidase were related to genes with miscellaneous functions. All these genes showed upregulation in the Xa21 lines. In addition, Os07g48020, Os0748050, Os09g29200, and Os12g08810 were upregulated in the NHIox line, and by SA treatment, except for Os12g08810; in contrast, OsO7g37730, Os09g29200, and Os10g28200 were downregulated in the NRRox line (Figure 3). Respiratory burst is an immediate response to a pathogen attack leading to the production of diverse reactive oxygen species (ROS) (Peltier et al., 2004). ROS generation mainly depends on NADPH oxidase and peroxidase activities. GSTs are a major group of enzymes that detoxify ROS produced after an infection (Hayes \& Pulford, 1995). A series of redox reactions are required to develop a cooperative network for antioxidant activity (Blokhina, Virolainen, \& Fagerstedt, 2003). In plants, hydrogen peroxide $\left(\mathrm{H}_{2} \mathrm{O}_{2}\right)$ is generated during the exposure to pathogen attack, and due to its relative stability the level of $\mathrm{H}_{2} \mathrm{O}_{2}$ is regulated by an array of catalases and peroxidases localized in almost all compartments of the plant cell (Blokhina et al., 2003). Therefore, the seven genes associated with respiratory burst might be components of a cooperative network for antioxidant activity mediated by Xa21 or NH1. 


\subsection{Signaling}

We identified 18 genes involved in signaling (Figure 3). Of them, eight encoded receptor-like protein kinases with an extracellular region and a transmembrane domain, and the others were kinases lacking these structures, a WD40-like protein, and a Tre-2/Bub2/Cdc16 (TBC)-domain-containing protein. The former group included three LRR-receptor-like protein kinases (Os05g40270, Os05g40270, and Os12g10740), one lectin-like receptor kinase (Os07g03900), one brassinosteroid insensitive 1 (BRI1)-associated receptor kinase (BAK, Os 11g39370), one wall-associated receptor kinase (OsWAK11, Os02g02120), and two less well defined receptor-like protein kinases $(O s 09 g 39650$ and $O s 11 g 46810)$. A functional association between lectin-like receptor kinases and the pathogen defense response was uncovered by identifying Arabidopsis LecRK-I.9. The knockout mutant had a gain-of-susceptibility phenotype and the activation mutant had enhanced resistance to Phytophthora brassicae (Bouwmeester et al., 2011), suggesting possible involvement of rice lectin-like receptor kinase in the defense response against bacterial pathogen challenge. BAK gene, Os11g39370, was upregulated in the NHIox and Xa21 lines and by BTH (SA) treatment, and was downregulated in the NRRox line. These results indicated that BAK was involved in SA-dependent signaling. Recent studies revealed that Arabidopsis BAK1 is an important regulator of pathogen-associated molecular pattern (PAMP) signaling (Bari \& Jones, 2009; Boller \& Felix, 2009; Schulze et al., 2010; Schwessinger et al., 2011). In addition, Arabidopsis receptor kinase flagellin sensitive 2 (FLS2)/BAK1 receptor complex triggers the accumulation of SA (Mersmann, Bourdais, Rietz, \& Robatzek, 2010; Mishina \& Zeier, 2007). This finding supported the significance of finding the above BAK gene in Xa21and NH1-mediated defense responses via SA signaling. Expression of the wall-associated receptor kinase gene (OsWAK11, Os02g02120) depended on NH1, XA21 and NRR. In summary, we expect that the BB defense mechanism may be modulated by diverse types of LRR-receptor-like kinases, including Xa21 (Song et al., 1995).

Among the non-receptor kinases, there were one mitogen-activated protein kinase kinase kinase (MAP3K) (Os11g10100) and two calcium/calmodulin-dependent protein kinases (CAMKs) (Os01g10890 and Os01g18800). MAP3Ks are components of the MAPK signaling cascade. Xa21 stimulated expression of Os1lg10100 (encoding a MAP3K) and NRR repressed its expression, suggesting that Os11g10100 may be involved in Xa21-mediated defense responses. Calcium/calmodulin-dependent signaling was also implicated in the BB defense response by transcriptome analysis (Figure 3). Os01g18800 was upregulated in the NHIox line and Os01g10890 was upregulated in the Xa21 line, while JA treatment repressed the expression of both genes. Regarding calcium signaling, four genes encoding calmodulin binding protein or calreticulin precursor protein might function upstream of these CAMKs. In addition, we identified two genes relating to G-proteins: one (Os12g31440) encoded a WD40-like protein and the other (Os02g48000) a TBC-domain-containing protein.

\subsection{Hormone Metabolism}

Based on our transcriptome analysis, there were 12 genes associated with hormone metabolism (Figure 3). Of these, two were related to ABA, five to ethylene signaling, three to JA signaling, and two to SA signaling. Plants infected with diverse pathogens change their levels of disease-responsive phytohormones such as JA and SA (Bari \& Jones, 2009). This report supported the significance of JA and SA signaling in disease resistance. Among the genes related to JA signaling, Os03g32314 encoding allene oxide cyclase 4 was upregulated in the Xa21 line and by JA treatment, and was downregulated in the NRRox line. Os12g37260 encoding lipoxygenase and Os12g37350 encoding lipozygenase also showed upregulation in response to JA treatment in NHIox and $\mathrm{Xa} 21$ lines. JA stimulated the expression of these genes, suggesting that they might be involved in a JA-dependent BB defense response. Allene oxide cyclase, along with allene oxide synthase, is a key enzyme in JA synthesis. Transgenic rice overexpressing a pathogen-inducible $O s A O S 2$ gene encoding allene oxide synthase showed JA-dependent induction of PR genes and enhanced Magnaporthe grisea (M. grisea) resistance (Mei, Qi, Sheng, \& Yang, 2006), supporting the possible involvement of allene oxide cyclase 4 in the BB defense response. Regarding ethylene signaling, we identified two genes (Os04g49194 and Os04g49210) encoding naringenin,2-oxoglutarate 3-dioxygenase, one (Os10g39140) encoding flavonol synthase/flavanone 3-hydroxylase, and two genes of unknown function (Os08g26820 and Os08g26840). All these genes were commonly upregulated in the NHIox line and by BTH treatment. In addition, Os04g49194, Os04g49210, and Os $10 g 39140$ were upregulated by JA treatment. Naringenin,2-oxoglutarate 3-dioxygenase with 1-aminocyclopropane-1-carboxylate (ACC) oxidase and flavanone 3-hydroxylase generates products such as ethylene and flavanone, a precursor of JA and SA. This result explains why Os04g49194, Os04g49210, and Os 10g39140 might be involved in multiple hormone signaling pathways. Regarding SA signaling, we identified two genes (Os02g48770 and Os05g01140) encoding S-adenosyl-L-methionin (SAM)/salicylic acid (SA)-dependent carboxyl methyltransferase which catalyzes the formation of methyl SA from SA. Both showed 
upregulation in NH1ox and Xa21 lines. This result suggested that SA signaling regulates a broad range of BB resistance response via these genes. In addition, Os $02 g 48770$ was upregulated by BTH and JA treatments. Crosstalk among different hormones for BB defense response could be enabled by $O s 02 g 48770$. We found two genes related to ABA metabolism. The involvement of ABA signaling in the regulation of Arabidopsis resistance to $R$. solanacearum was demonstrated by the enhanced susceptibility of abil-1 and abi2-1, two ABA-insensitive mutants (Hernandez-Blanco et al. 2007). This finding supports the role of ABA signaling in BB disease resistance of rice. Direct evidence will require functional analysis using genetic approaches.

\subsection{Transcriptional Regulation}

Eight genes related to transcriptional regulation were identified (Figure 3). These included seven WRKY transcription factors (TFs) (Os05g46020, Os09g25060, Os09g25070, Os11g02530, Os11g02540, Os12g02450, and $O s 12 g 02470$ ), and an apetalata2 and ethylene responsive transcription factor (AP2/ERF, Os09g20350) (Figure 3). Among the TFs, the WRKY gene family is typically responsible for enhanced pathogen defense (Pandey \& Somssich, 2009a) and is the most abundant TF related to enhanced BB resistance (Figure 3). Os09g25060 (OsWRKY76), Os09g25070 (OsWRKY62), Os1 lg02530 (OsWRKY40), Os1lg02540 (OsWRKY50), Os12g02450 (OsWRKY64) and Os12g02470 (OsWRKY65) were upregulated in the NH1ox and Xa21 lines. Of these, OsWRKY50, OsWRKY62, and OsWRKY76 were also downregulated in the NRRox line, and OsWRKY40 and OsWRKY64 were upregulated by SA and JA treatments. Os05g46020 (OsWRKY7) was upregulated in the Xa21 line and by SA and JA treatments, and was downregulated in the NRRox line. Therefore, most WRKYs identified in this study were differentially expressed by multiple factors, suggesting they might be involved in a broad range of $\mathrm{BB}$ defense responses. Identification of multiple WRKY genes suggested diversity in the detailed mechanism triggering $\mathrm{BB}$ defense responses.

In the AP2/ERF family, one gene (Os09g20350) was related to a broad range of BB resistance. This gene was upregulated in the Xa21 line and downregulated in the NRRox line. Tobacco (Nicotiana tabacum) osmotin promoter binding protein 1 (OPBP1) which belongs to the AP2/ERF family is involved in enhanced resistance to Pseudomonas syringae pv tabaci and Phytophthora parasitica var nicotianae (Guo, Chen, Wu, Ling, \& Xu, 2004). Overexpressing Arabidopsis cytokinin response factor 5 (CRF5) which belongs to the AP2/ERF family increases pathogen resistance and concomitantly activates the expression of a large number of GCC-box pathogenesis-related genes (Liang et al., 2010). These studies suggested that the function of a rice $A P 2 / E R F$ gene might be associated with multiple BB defense responses as demonstrated by transcriptome analysis.

\subsection{Pathogenesis Related Protein, Secondary Metabolism and Protein Degradation}

To date, 17 groups of pathogenesis-related (PR) genes have been identified (Sels, Mathys, De Coninck, Cammue, \& De Bolle, 2008). Two hundred fifty-six putative PR genes were identified from Greenphyl (http://greenphyl.cirad.fr/v2/cgi-bin/index.cgi), a phylogenomic database for plant comparative genomics (Rouard et al., 2011). Of these PR protein genes, 10 were related to multiple BB resistance responses in our analysis. Four genes encoding pathogenesis-related Bet v I family protein (PR10) (Os03g18850, Os12g36830, $O s 12 g 36860$, and $O s 12 g 36880$ ) were found to be significantly upregulated in Xa21 and NH1ox lines. In addition, Os 12g36830, Os 12g36860, and Os $12 g 36880$ were also upregulated by SA and JA treatments. In the PR2 family, we identified three genes: two $(O s 01 g 71350$ and $O s 05 g 31140)$ encoding glycosyl hydrolase family 17 proteins and one $(O s 07 g 35560)$ encoding a glucan endo-1,3-beta-glucosidase. All of these genes were upregulated in the Xa21 line and by JA treatment (Figure 3). In addition, Os01g71350 was upregulated in the NHIox line, and Os05g31140 and Os07g35560 were downregulated in the NRRox line (Figure 3). Two PR3 family genes were identified. Os $1 \lg 37950$ and Os1 lg37960 encoded wound-induced proteins (WIP). Expression of Os 1 lg37950 and Os1lg37960 was upregulated in Xa21 and NHlox lines (Figure 3). In addition, Os11g37950 was upregulated by JA treatment (Figure 3). Os $12 g 43380$ encodes thaumatin belonging to the PR-5 family and was upregulated in Xa21 and NH1ox lines, as well as by SA and JA treatments (Figure 3). PR proteins are a group of heterogeneous proteins encoded by genes that are rapidly induced in response to a pathogen. Elevated expression of $P R$ genes is associated with systemic acquired resistance (SAR), emphasizing the requirement of $P R$ gene expression for enhanced defense response to BB attack (Seo, Lee, Xiang, \& Park, 2008).

We identified 13 and 21 genes involved in secondary metabolism and protein degradation, respectively. These functional groups are also known to contain active molecules for defense response against pathogen attack because higher concentrations of secondary metabolites might result in a more resistant plant (Bednarek, 2012). Exact roles of genes in these functional groups remain to be characterized.

Validation of expression patterns for candidate genes in the mainstream signaling pathway associated with multiple defense responses against bacterial blight disease. 
To validate expression patterns of candidate genes in the mainstream signaling pathway associated with multiple defense responses against bacterial blight disease from our study, we carried out real-time PCR analysis for 8 genes belonging to RNA category and 10 to pathogenesis (PR) related protein group in Figure 3. As a result, we confirmed that 7 WRKY genes except AP2/ERF gene in RNA category were upregulated in NH1ox and Xa21 lines compared to their background varieties, LG and TP309, in response to Xoo (Figure 5, Figure S1). In case of PR genes, all genes except glycosyl hydrolase ( $\mathrm{GH} 17, \mathrm{Os} 05 \mathrm{~g} 31140)$ were upregulated in Xa21 line compared with TP309, and expression patterns of PRs (Os03g18850, Os12g36830 Os12g36860, and Os12g36880), WIP3 (Os11g37950) and glucanase (Os07g35560) genes were upregulated in NH1ox line compared with LG. Based on this data, 4 PR, WIP3 and glucanase genes are expected to function downstream of multiple defense signaling pathways mediated by Xa21 or NH1, while WIP4 (Os11g37960), Thaumatin (Os12g43380), and GH17 (Os01g71350) genes show Xa21 dependent response (Figure 5, Figure S1). This result indicates that candidate genes from our transcriptome data are mostly relevant for further functional analysis to elucidate defense singling pathways associated with $\mathrm{Xa21}$ or $\mathrm{NH} 1$.

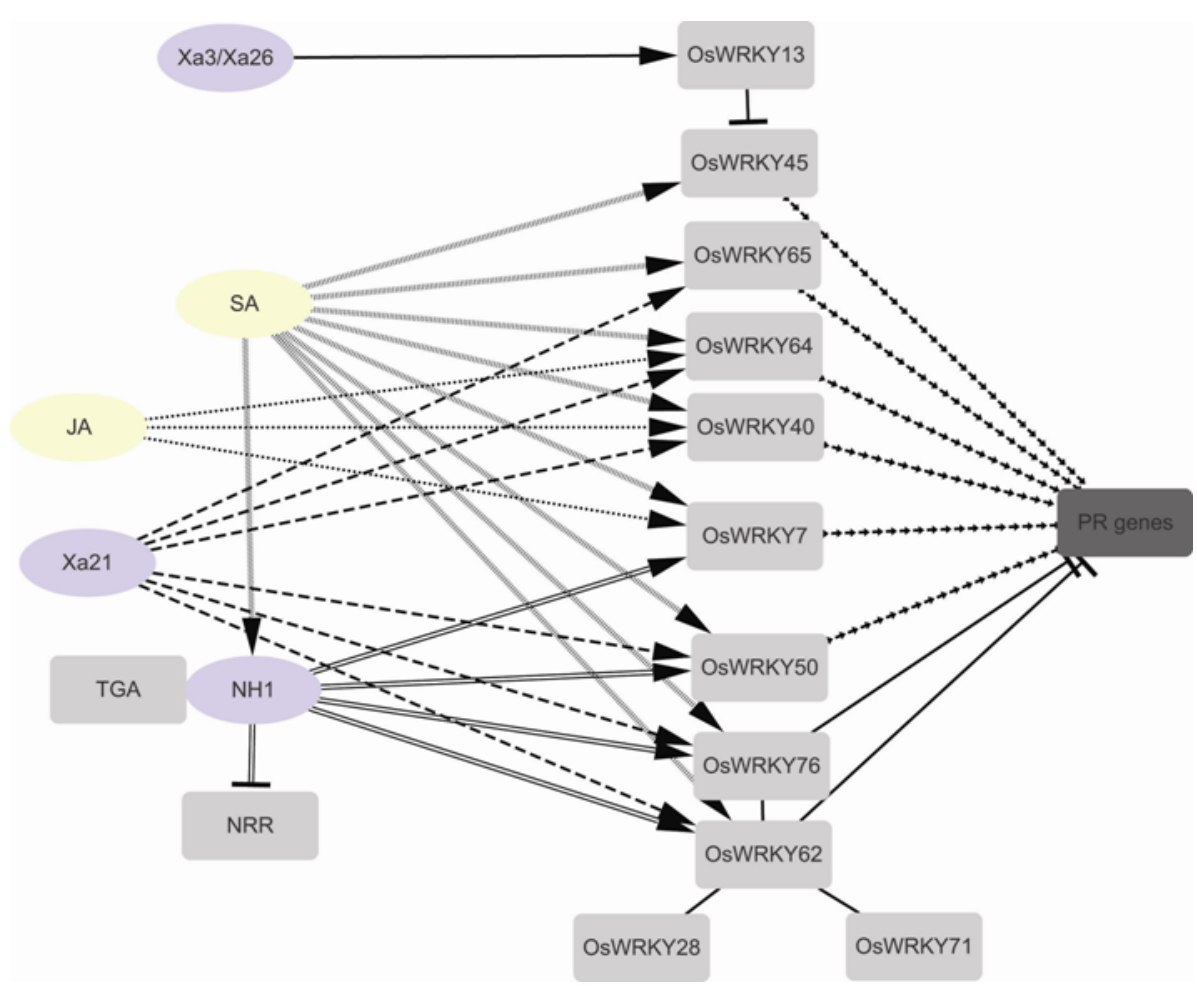

Figure 5. Model of WRKY transcription factors mediating bacterial blight defense responses in rice. Differential expression patterns in Figure 3 were used to develop a model of bacterial blight defense responses. SA and JA in yellow circles are phyotohormones; $\mathrm{Xa21}, \mathrm{Xa3} / \mathrm{Xa26}$, and $\mathrm{NH} 1$ in weak purple circles are defense genes with known function; genes in weak gray boxes are downstream transcriptional regulators of Xa21, Xa3/Xa26, and NH1 genes; and PR genes are indicated as dark gray box

\section{Conclusion}

Transcriptome analyses using multiple resistance lines or an enhanced-susceptible line against BB revealed diverse views of enhanced BB resistance response. Genes associated with disease resistance, and hormones such as SA and JA, are good candidates to study the molecular mechanism of an enhanced BB defense response (Table S1). Out of our candidate genes in Table S1, functions of 43 genes were identified and 8 of them are related to defense responses (Table S6), suggesting that our transcriptome analysis retains useful information to elucidate molecular mechanism underlining enhanced defense responses against pathogen attack or pathogen responses. Especially, NH1 is functionally related to multiple WRKYs including three WRKY genes previously characterized: two (OsWRKY62 and OsWRKY76) belonging to the WRKY II-a subfamily, one (OsWRKY7) to WRKY II-c, and two (OsWRKY64 and OsWRKY65) to WRKY III. These data suggested that NH1 mediated diverse defense mechanisms in rice through different types of WRKY subfamilies. Thus, NH1 may be a hub 
modulator of broad-spectrum BB resistance, like Arabidopsis NPR1 (Wang, Amornsiripanitch, \& Dong, 2006). The functional association with WRKY and NH1 is supported by the recent study that Arabidopsis NPRI was functionally associated with six WRKYs (WRKY18, WRKY38, WRKY53, WRKY54, WRKY58, and WRKY70) (ref plos genetics). In addition, Arabidopsis WRKY6, an OsWRKY1 ortholog, was found to be active during NPR1-dependent defense priming by $\beta$-amino-butyric acid (Van der Ent et al., 2009). This finding further enhances the functional association between WRKY TFs and NH1. Functions of uncharacterized WRKY genes for enhanced BB defense response remain to be determined. In addition to the above-mentioned WRKYs, OsWRKY13 mediates the defense response downstream of Xa1 and Xa3/Xa26 (Kou \& Wang, 2011) and OsWRKY45-1 negatively regulates rice resistance to Xoo in an SA-induced and NH1-independent manner (Tao et al., 2009), indicating that transcriptional regulation, mainly modulated by the WRKY family, plays a central role in BB defense signaling (Liu, Bai, Wang, \& Chu, 2007; Pandey \& Somssich, 2009b; Peng, Bartley, Canlas, $\&$ Ronald, 2010; Peng et al., 2008; Qiu et al., 2007; Ryu et al., 2006; Tao et al., 2009). Since OsWRKY13 binds to OsWRKY45-1 promoters and negatively regulates its expression (Tao et al., 2009), we expect that an understanding of the mutual regulation among WRKY genes would provide important clues to explain enhanced defense responses mediated by these TFs.

Mainstream processes for disease resistance signaling pathways were well represented. Assignment of candidates from our transcriptome analyses into each step of the pathway could provide a useful molecular framework to study the defense mechanism through signaling pathways. Ninety-four genes were mapped to nine processes in the mainstream pathway for enhanced BB resistance response. Further functional elucidation of these candidate genes will clarify the detailed molecular mechanism. The integration and refinement of multiple omics data related to BB resistance provides useful information to design or develop crops with enhanced BB defense capabilities. To expand the Xa21- and NH1-mediated defense signaling pathway based on the stress interactome that was recently established, we might need to apply a functional gene networking tool for rice genes with 94 mainstream candidates for enhanced BB resistance response. The information of differentially expressed new linkages associated with Xa21 and NH1 provided the clues for key players associated with enhanced defense response against bacterial blight disease. Systematic functional analysis of the main candidate genes identified in this study might accelerate the discovery of the molecular mechanism for enhanced Xoo resistance response.

\section{Acknowledgements}

This work was supported by Cooperative Research Program for Agriculture Science \& Technology Development (Project title: Construction of rice signalom network for regulating hormone biosynthesis and metabolism and the identification of the key regulator for enhancing crop yield, Project No.PJ00951405 to KHJ and Project title: Identification and application of resistant genes in rice cultivars via study of non-RD kinase: nRDA41 and nRDK08, Project No.PJ00809801 to SWL) Rural Development Administration, Republic of Korea and the Mid-Career Researcher Program (NRF-2013R1A2A2A01068887 to JSJ) of the Korean Ministry of Education, Science, and Technology.

\section{References}

Bari, R., \& Jones, J. (2009). Role of plant hormones in plant defence responses. Plant Mol Biol, 69(4), 473-488. http://dx.doi.org/10.1007/s11103-008-9435-0

Barrett, T., Troup, D. B., Wilhite, S. E., Ledoux, P., Evangelista, C., Kim, I. F., ... Soboleva, A. (2011). NCBI GEO: archive for functional genomics data sets--10 years on. Nucleic Acids Res, 39(Database issue), D1005-1010. http://dx.doi.org/10.1093/nar/gkq1184

Belkhadir, Y., Jaillais, Y., Epple, P., Balsemao-Pires, E., Dangl, J. L., \& Chory, J. (2012). Brassinosteroids modulate the efficiency of plant immune responses to microbe-associated molecular patterns. Proc Natl Acad Sci U S A, 109(1), 297-302. http://dx.doi.org/10.1073/pnas.1112840108

Blokhina, O., Virolainen, E., \& Fagerstedt, K. V. (2003). Antioxidants, oxidative damage and oxygen deprivation stress: a review. Ann Bot, 91 Spec No, 179-194. http://dx.doi.org/10.1093/aob/mcf118

Boller, T., \& Felix, G. (2009). A renaissance of elicitors: perception of microbe-associated molecular patterns and danger signals by pattern-recognition receptors. Annu Rev Plant Biol, 60, 379-406. http://dx.doi.org/10.1146/annurev.arplant.57.032905.105346

Bouwmeester, K., de Sain, M., Weide, R., Gouget, A., Klamer, S., Canut, H., \& Govers, F. (2011). The Lectin Receptor Kinase LecRK-I.9 Is a Novel Phytophthora Resistance Component and a Potential Host Target for a RXLR Effector. PLoS Pathog, 7(3). http://dx.doi.org/ARTN e1001327 
Bryan, G. T., Wu, K. S., Farrall, L., Jia, Y. L., Hershey, H. P., McAdams, S. A., ... Valent, B. (2000). A single amino acid difference distinguishes resistant and susceptible alleles of the rice blast resistance gene Pi-ta. Plant Cell, 12(11), 2033-2045. http://dx.doi.org/10.1105/tpc.12.11.2033

Cao, P., Jung, K. H., Choi, D., Hwang, D., \& Ronald, P. C. (2012). The Rice Oligonucleotide Array Database: an atlas of rice gene expression. Rice, 5(6), 17. http://dx.doi.org/10.1186/1939-8433-5-17

Dardick, C., \& Ronald, P. (2006). Plant and animal pathogen recognition receptors signal through non-RD kinases. PLoS Pathog, 2(1), e2. http://dx.doi.org/10.1371/journal.ppat.0020002

Delteil, A., Zhang, J., Lessard, P., \& Morel, J. B. (2010). Potential Candidate Genes for Improving Rice Disease Resistance. Rice, 3(1), 56-71. http://dx.doi.org/10.1007/s12284-009-9035-X

Desaki, Y., Miya, A., Venkatesh, B., Tsuyumu, S., Yamane, H., Kaku, H., ... Shibuya, N. (2006). Bacterial lipopolysaccharides induce defense responses associated with programmed cell death in rice cells. Plant Cell Physiol, 47(11), 1530-1540. http://dx.doi.org/10.1093/pcp/pcl019

Desclos-Theveniau, M., Arnaud, D., Huang, T. Y., Lin, G. J. C., Chen, W. Y., Lin, Y. C., \& Zimmerli, L. (2012). The Arabidopsis Lectin Receptor Kinase LecRK-V.5 Represses Stomatal Immunity Induced by Pseudomonas syringae pv. tomato DC3000. PLoS Pathog, $8(2)$. http://dx.doi.org/10.1371/journal.ppat.1002513

Ellerbrock, B., Kim, J. H., \& Jander, G. (2007). Contribution of glucosinolate transport to Arabidopsis defense responses. Plant Signal Behav, 2(4), 282-283. http://dx.doi.org/10.4161/psb.2.4.4014

Goodstein, D. M., Shu, S., Howson, R., Neupane, R., Hayes, R. D., Fazo, J., ... Rokhsar, D. S. (2012). Phytozome: a comparative platform for green plant genomics. Nucleic Acids Res, 40(Database issue), D1178-1186. http://dx.doi.org/10.1093/nar/gkr944

Grant, M., Brown, I., Adams, S., Knight, M., Ainslie, A., \& Mansfield, J. (2000). The RPM1 plant disease resistance gene facilitates a rapid and sustained increase in cytosolic calcium that is necessary for the oxidative burst and hypersensitive cell death. Plant Journal, 23(4), 441-450. http://dx.doi.org/10.1046/j.1365-313x.2000.00804.x

Gu, H., Zhu, P., Jiao, Y., Meng, Y., \& Chen, M. (2011). PRIN: a predicted rice interactome network. BMC Bioinformatics, 12(1), 161. http://dx.doi.org/10.1186/1471-2105-12-161

Guo, Z. J., Chen, X. J., Wu, X. L., Ling, J. Q., \& Xu, P. (2004). Overexpression of the AP2/EREBP transcription factor OPBP1 enhances disease resistance and salt tolerance in tobacco. Plant Mol Biol, 55(4), 607-618.

Hayes, J. D., \& Pulford, D. J. (1995). The glutathione S-transferase supergene family: regulation of GST and the contribution of the isoenzymes to cancer chemoprotection and drug resistance. Crit Rev Biochem Mol Biol, 30(6), 445-600. http://dx.doi.org/10.3109/10409239509083491

Jeung, J. U., Kim, B. R., Cho, Y. C., Han, S. S., Moon, H. P., Lee, Y. T., \& Jena, K. K. (2007). A novel gene, Pi40(t), linked to the DNA markers derived from NBS-LRR motifs confers broad spectrum of blast resistance in rice. Theoretical and Applied Genetics, 115(8), 1163-1177. http://dx.doi.org/10.1007/s00122-007-0642-x

Jung, K. H., \& An, G. (2012). Application of MapMan and RiceNet Drives Systematic Analyses of the Early Heat Stress Transcriptome in Rice Seedlings. $J$ Plant Biol, 55(5), in press. http://dx.doi.org/10.1007/s12374-012-0270-0

Jung, K. H., Dardick, C., Bartley, L. E., Cao, P., Phetsom, J., Canlas, P., ... Ronald, P. C. (2008). Refinement of light-responsive transcript lists using rice oligonucleotide arrays: evaluation of gene-redundancy. PLoS ONE, 3(10), e3337. http://dx.doi.org/10.1371/journal.pone.0003337

Jung, K. H., Han, M. J., Lee, D. Y., Lee, Y. S., Schreiber, L., Franke, R., ... An, G. (2006). Wax-deficient anther1 is involved in cuticle and wax production in rice anther walls and is required for pollen development. Plant Cell, 18(11), 3015-3032. http://dx.doi.org/10.1105/tpc.106.042044

Jung, K. H., Jeon, J. S., \& An, G. (2011). Web Tools for Rice Transcriptome Analyses. Journal of Plant Biology, 54(2), 65-80. http://dx.doi.org/10.1007/s12374-011-9146-y

Kou, Y., \& Wang, S. (2011). Toward an understanding of the molecular basis of quantitative disease resistance in rice. J Biotechnol. http://dx.doi.org/10.1016/j.jbiotec.2011.07.002 
Lee, I., Seo, Y. S., Coltrane, D., Hwang, S., Oh, T., Marcotte, E. M., \& Ronald, P. C. (2011). Genetic dissection of the biotic stress response using a genome-scale gene network for rice. Proc Natl Acad Sci U S A, 108(45), 18548-18553. http://dx.doi.org/10.1073/pnas.1110384108

Lee, S.-W., Han, M., Park, C.-J., Seo, Y.-S., BARTLEY, L. E., \& Jeon, J.-S. (2011). The Molecular Mechanisms of Rice Resistance to the Bacterial Blight Pathogen, Xanthomonas oryzae pathovar oryzae. In J.-C. Kader \& M. Delseny (Eds.), Advances in Botanical Research (Vol. 60, pp. 51-87). San Diego: Academic Press.

Lee, S. W., Han, S. W., Sririyanum, M., Park, C. J., Seo, Y. S., \& Ronald, P. C. (2009). A type I-secreted, sulfated peptide triggers XA21-mediated innate immunity. Science, 326(5954), 850-853. http://dx.doi.org/326/5954/850

Liang, Y. S., Ermawati, N., Cha, J. Y., Jung, M. H., Su'udi, M., Kim, M. G., ... Son, D. (2010). Overexpression of an AP2/ERF-type Transcription Factor CRF5 Confers Pathogen Resistance to Arabidopsis Plants. Journal of the Korean Society for Applied Biological Chemistry, 53(2), 142-148. http://dx.doi.org/10.3839/jksabc.2010.024

Lin, F., Chen, S., Que, Z., Wang, L., Liu, X., \& Pan, Q. (2008). The blast resistance gene Pi37 encodes an NBS-LRR protein and is a member of a resistance gene cluster on rice chromosome 1. Phytopathology, 98(6), S90-S90.

Liu, X., Bai, X., Wang, X., \& Chu, C. (2007). OsWRKY71, a rice transcription factor, is involved in rice defense response. J Plant Physiol, 164(8), 969-979. http://dx.doi.org/10.1016/j.jplph.2006.07.006

Long, Y., Zhao, L., Niu, B., Su, J., Wu, H., Chen, Y., ... Liu, Y. G. (2008). Hybrid male sterility in rice controlled by interaction between divergent alleles of two adjacent genes. Proc Natl Acad Sci U S A, 105(48), 18871-18876. http://dx.doi.org/10.1073/pnas.0810108105

Lu, R., Lee, G. C., Shultz, M., Dardick, C., Jung, K., Phetsom, J., ... Rocke, D. M. (2008). Assessing probe-specific dye and slide biases in two-color microarray data. BMC Bioinformatics, 9, 314. http://dx.doi.org/10.1186/1471-2105-9-314

Mackey, D., Holt, B. F., Wiig, A., \& Dangl, J. L. (2002). RIN4 interacts with Pseudomonas syringae type III effector molecules and is required for RPM1-mediated resistance in Arabidopsis. Cell, 108(6), 743-754. http://dx.doi.org/10.1016/S0092-8674(02)00661-X

Mei, C., Qi, M., Sheng, G., \& Yang, Y. (2006). Inducible overexpression of a rice allene oxide synthase gene increases the endogenous jasmonic acid level, PR gene expression, and host resistance to fungal infection. Mol Plant Microbe Interact, 19(10), 1127-1137. http://dx.doi.org/10.1094/MPMI-19-1127

Mersmann, S., Bourdais, G., Rietz, S., \& Robatzek, S. (2010). Ethylene signaling regulates accumulation of the FLS2 receptor and is required for the oxidative burst contributing to plant immunity. Plant Physiol, 154(1), 391-400. http://dx.doi.org/10.1104/pp.110.154567

Mishina, T. E., \& Zeier, J. (2007). Pathogen-associated molecular pattern recognition rather than development of tissue necrosis contributes to bacterial induction of systemic acquired resistance in Arabidopsis. Plant Journal, 50(3), 500-513. http://dx.doi.org/10.1111/j.1365-313X.2007.03067.x

Mutwil, M., Klie, S., Tohge, T., Giorgi, F. M., Wilkins, O., Campbell, M. M., ... Persson, S. (2011). PlaNet: Combined Sequence and Expression Comparisons across Plant Networks Derived from Seven Species. Plant Cell, 23(3), 895-910. http://dx.doi.org/10.1105/tpc.111.083667

Nino-Liu, D. O., Ronald, P. C., \& Bogdanove, A. J. (2006). Xanthomonas oryzae pathovars: model pathogens of a model crop. Mol Plant Pathol, 7(5), 303-324. http://dx.doi.org/10.1111/j.1364-3703.2006.00344.x

Okuyama, Y., Kanzaki, H., Abe, A., Yoshida, K., Tamiru, M., Saitoh, H., ... Terauchi, R. (2011). A multifaceted genomics approach allows the isolation of the rice Pia-blast resistance gene consisting of two adjacent $\begin{array}{lllll}\text { NBS-LRR protein } & \text { genes. }\end{array}$ http://dx.doi.org/10.1111/j.1365-313X.2011.04502.x

Pandey, S. P., \& Somssich, I. E. (2009a). The Role of WRKY Transcription Factors in Plant Immunity. Plant Physiology, 150(4), 1648-1655. http://dx.doi.org/10.1104/pp.109.138990

Pandey, S. P., \& Somssich, I. E. (2009b). The role of WRKY transcription factors in plant immunity. [Review]. Plant Physiol, 150(4), 1648-1655. http://dx.doi.org/10.1104/pp.109.138990 
Peltier, J. B., Ytterberg, A. J., Sun, Q., \& van Wijk, K. J. (2004). New functions of the thylakoid membrane proteome of Arabidopsis thaliana revealed by a simple, fast, and versatile fractionation strategy. J Biol Chem, 279(47), 49367-49383. http://dx.doi.org/10.1074/jbc.M406763200

Peng, Y., Bartley, L. E., Canlas, P., \& Ronald, P. C. (2010). OsWRKY IIa Transcription Factors Modulate Rice Innate Immunity. Rice, 3(1), 36-42. http://dx.doi.org/10.1007/s12284-010-9039-6

Peng, Y., Bartley, L. E., Chen, X. W., Dardick, C., Chern, M. S., Ruan, R., ... Ronald, P. C. (2008). OsWRKY62 is a negative regulator of basal and Xa21-mediated defense against Xanthomonas oryzae pv. oryzae in rice. Molecular Plant, 1(3), 446-458. http://dx.doi.org/10.1093/mp/ssn024

Qi, L., Yan, J., Li, Y., Jiang, H., Sun, J., Chen, Q., ... Li, C. (2012). Arabidopsis thaliana plants differentially modulate auxin biosynthesis and transport during defense responses to the necrotrophic pathogen Alternaria brassicicola. New Phytol, 195(4), 872-882. http://dx.doi.org/10.1111/j.1469-8137.2012.04208.x

Qiu, D. Y., Xiao, J., Ding, X. H., Xiong, M., Cai, M., Cao, C. L., ... Wang, S. P. (2007). OsWRKY13 mediates rice disease resistance by regulating defense-related genes in salicylate- and jasmonate-dependent signaling. Molecular Plant-Microbe Interactions, 20(5), 492-499. http://dx.doi.org/10.1094/Mpmi-20-5-0492

Rocke, D. M. (2004). Design and analysis of experiments with high throughput biological assay data. Semin Cell Dev Biol, 15(6), 703-713. http://dx.doi.org/10.1016/j.semcdb.2004.09.007

Rouard, M., Guignon, V., Aluome, C., Laporte, M. A., Droc, G., Walde, C., ... Conte, M. G. (2011). GreenPhylDB v2.0: comparative and functional genomics in plants. Nucleic Acids Res, 39(Database issue), D1095-1102. http://dx.doi.org/10.1093/nar/gkq811

Ryu, H. S., Han, M., Lee, S. K., Cho, J. I., Ryoo, N., Heu, S., ... Jeon, J. S. (2006). A comprehensive expression analysis of the WRKY gene superfamily in rice plants during defense response. Plant Cell Rep, 25(8), 836-847. http://dx.doi.org/10.1007/s00299-006-0138-1

Schulze, B., Mentzel, T., Jehle, A. K., Mueller, K., Beeler, S., Boller, T., ... Chinchilla, D. (2010). Rapid heteromerization and phosphorylation of ligand-activated plant transmembrane receptors and their associated kinase BAK1. J Biol Chem, 285(13), 9444-9451. http://dx.doi.org/10.1074/jbc.M109.096842

Schwessinger, B., Roux, M., Kadota, Y., Ntoukakis, V., Sklenar, J., Jones, A., \& Zipfel, C. (2011). Phosphorylation-dependent differential regulation of plant growth, cell death, and innate immunity by the regulatory receptor-like kinase BAK1. PLoS Genet, 7(4), e1002046. http://dx.doi.org/10.1371/journal.pgen.1002046

Sels, J., Mathys, J., De Coninck, B. M. A., Cammue, B. P. A., \& De Bolle, M. F. C. (2008). Plant pathogenesis-related (PR) proteins: A focus on PR peptides. Plant Physiology and Biochemistry, 46(11), 941-950. http://dx.doi.org/10.1016/j.plaphy.2008.06.011

Seo, P. J., Lee, A. K., Xiang, F. N., \& Park, C. M. (2008). Molecular and functional profiling of Arabidopsis pathogenesis-related genes: Insights into their roles in salt response of seed germination. Plant and Cell Physiology, 49(3), 334-344. http://dx.doi.org/10.1093/Pcp/Pcn011

Seo, Y. S., Chern, M., Bartley, L. E., Han, M., Jung, K. H., Lee, I., ... Ronald, P. C. (2011). Towards establishment of a rice stress response interactome. PLoS Genet, 7(4), e1002020. http://dx.doi.org/10.1371/journal.pgen.1002020

Shimono, M., Koga, H., Akagi, A., Hayashi, N., Goto, S., Sawada, M., ... Takatsuji, H. (2012). Rice WRKY45 plays important roles in fungal and bacterial disease resistance. Mol Plant Pathol, 13(1), 83-94. http://dx.doi.org/10.1111/j.1364-3703.2011.00732.x

Shimono, M., Sugano, S., Nakayama, A., Jiang, C. J., Ono, K., Toki, S., \& Takatsuji, H. (2007). Rice WRKY45 plays a crucial role in benzothiadiazole-inducible blast resistance. Plant Cell, 19(6), 2064-2076. http://dx.doi.org/10.1105/tpc.106.046250

Song, W. Y., Wang, G. L., Chen, L. L., Kim, H. S., Pi, L. Y., Holsten, T., ... Ronald, P. (1995). A receptor kinase-like protein encoded by the rice disease resistance gene, Xa21. Science, 270(5243), 1804-1806. http://dx.doi.org/10.1126/science.270.5243.1804

Sun, S., Gu, M., Cao, Y., Huang, X., Zhang, X., Ai, P., ... Xu, G. (2012). A constitutive expressed phosphate transporter, OsPht 1 , modulates phosphate uptake and translocation in phosphate-replete rice. Plant Physiol, 159(4), 1571-1581. http://dx.doi.org/10.1104/pp.112.196345 
Tao, Z., Liu, H., Qiu, D., Zhou, Y., Li, X., Xu, C., \& Wang, S. (2009). A pair of allelic WRKY genes play opposite roles in rice-bacteria interactions. Plant Physiol, 151(2), 936-948. http://dx.doi.org/10.1104/pp.109.145623

Tena, G., Boudsocq, M., \& Sheen, J. (2011). Protein kinase signaling networks in plant innate immunity. Curr Opin Plant Biol., 14(5), 519-529. http://dx.doi.org/10.1016/j.pbi.2011.05.006

Urbanczyk-Wochniak, E., Usadel, B., Thimm, O., Nunes-Nesi, A., Carrari, F., Davy, M., ... Fernie, A. R. (2006). Conversion of MapMan to allow the analysis of transcript data from Solanaceous species: effects of genetic and environmental alterations in energy metabolism in the leaf. Plant Mol Biol, 60(5), 773-792. http://dx.doi.org/10.1007/s11103-005-5772-4

Usadel, B., Nagel, A., Thimm, O., Redestig, H., Blaesing, O. E., Palacios-Rojas, N., ... Stitt, M. (2005). Extension of the visualization tool MapMan to allow statistical analysis of arrays, display of corresponding genes, and comparison with known responses. Plant Physiol, 138(3), 1195-1204. http://dx.doi.org/10.1104/pp.105.060459

Van der Ent, S., Van Hulten, M., Pozo, M. J., Czechowski, T., Udvardi, M. K., Pieterse, C. M. J., \& Ton, J. (2009). Priming of plant innate immunity by rhizobacteria and beta-aminobutyric acid: differences and similarities in regulation. New Phytologist, 183(2), 419-431. http://dx.doi.org/10.1111/j.1469-8137.2009.02851.x

Wang, D., Amornsiripanitch, N., \& Dong, X. N. (2006). A genomic approach to identify regulatory nodes in the transcriptional network of systemic acquired resistance in plants. PLoS Pathog, 2(11), 1042-1050. http://dx.doi.org/10.1371/journal.ppat.0020123

Wang, J., Nygaard, V., Smith-Sorensen, B., Hovig, E., \& Myklebost, O. (2002). MArray: analysing single, replicated or reversed microarray experiments. Bioinformatics, 18(8), 1139-1140. http://dx.doi.org/10.1093/bioinformatics/18.8.1139

Yoshimura, S., Yamanouchi, U., Katayose, Y., Toki, S., Wang, Z. X., Kono, I., ... Sasaki, T. (1998). Expression of $\mathrm{Xa1}$, a bacterial blight-resistance gene in rice, is induced by bacterial inoculation. Proc Natl Acad Sci US A, 95(4), 1663-1668. http://dx.doi.org/10.1073/pnas.95.4.1663

Youens-Clark, K., Buckler, E., Casstevens, T., Chen, C., DeClerck, G., Derwent, P., ... Ware, D. (2011). Gramene database in 2010: updates and extensions. Nucleic Acids Res, 39, D1085-D1094. http://dx.doi.org/10.1093/Nar/Gkq1148

Yuan, Y., Zhong, S., Li, Q., Zhu, Z., Lou, Y., Wang, L., ... He, Z. (2007). Functional analysis of rice NPR1-like genes reveals that OsNPR1/NH1 is the rice orthologue conferring disease resistance with enhanced herbivore susceptibility. Plant Biotechnol J, 5(2), 313-324. http://dx.doi.org/10.1111/j.1467-7652.2007.00243.x 


\section{Supplementary data/Materials}


Figure S1. Real-time PCR analysis of genes belonging to RNA and pathogen related protein categories

Table S1. List and microarray data of genes associated with enhanced bacterial blight resistance

\begin{tabular}{|c|c|c|c|c|c|c|c|c|}
\hline Locus_id & Putative Function & $\begin{array}{c}\log _{2} \\
\text { NRRox(SS)/ } \\
\text { LG(S)_1d } \\
\end{array}$ & $\begin{array}{c}\log _{2} \\
\text { NH1ox(R)/ } \\
\text { LG(S)_1d }\end{array}$ & $\begin{array}{c}\log _{2} \\
\mathrm{Xa} 21(\mathrm{R}) / \\
\text { TP309(S)_2d }\end{array}$ & $\begin{array}{c}\log _{2} \\
\text { BTH(hormone)/ } \\
\text { Mock } \\
\end{array}$ & $\begin{array}{c}\log _{2} \\
\text { JA(hormone)/ } \\
\text { Mock_leaf } \\
\end{array}$ & $\begin{array}{c}\log _{2} \\
\text { LPS(elicitor)/ } \\
\text { Mock } \\
\end{array}$ & Feature \\
\hline LOC_Os01g01080 & decarboxylase, putative, expressed & -0.62166 & 0.113813 & 1.032885 & & & & Figure 4 \\
\hline LOC_Os01g01160 & $\begin{array}{l}\text { heat shock protein DnaJ, putative, } \\
\text { expressed }\end{array}$ & 0.50816 & 1.146319 & 0.782804 & & & & Figure 4 \\
\hline LOC_Os01g01180 & expressed protein & 0.484002 & 1.028018 & 1.185149 & & & & Figure 4 \\
\hline LOC_Os01g01710 & $\begin{array}{l}\text { 1-deoxy-D-xylulose 5-phosphate } \\
\text { reductoisomerase, chloroplast } \\
\text { precursor, putative, expressed }\end{array}$ & -0.73341 & -0.22451 & 1.15928 & & & 0.60495 & Figure 4 \\
\hline LOC_Os01g01840 & $\begin{array}{l}\text { helix-loop-helix DNA-binding } \\
\text { domain containing protein, } \\
\text { expressed }\end{array}$ & -1.57286 & 2.032539 & 0.616171 & 6.470884 & -0.58151 & & Figure 4 \\
\hline LOC_Os01g04280 & $\begin{array}{l}\text { calmodulin binding protein, } \\
\text { putative, expressed }\end{array}$ & -0.83571 & 0.998188 & -0.22336 & 1.556207 & 0.374425 & 1.71215 & Figure 4 \\
\hline LOC_Os01g10590 & $\begin{array}{l}\text { osFTL8 FT-Like8 homologous to } \\
\text { Flowering Locus T gene; contains } \\
\text { Pfam profile PF01161: } \\
\text { Phosphatidylethanolamine-binding } \\
\text { protein, expressed }\end{array}$ & -0.75864 & 1.32332 & 0.1833 & & & & Figure 4 \\
\hline LOC_Os01g13590 & $\begin{array}{l}\text { isoflavone reductase homolog IRL, } \\
\text { putative, expressed }\end{array}$ & 0.829176 & 1.694336 & 1.035175 & & & & Figure 4 \\
\hline
\end{tabular}




\begin{tabular}{|c|c|c|c|c|c|c|c|c|}
\hline LOC_Os01g14250 & expressed protein & 1.172973 & 2.053824 & 0.75785 & & & & Figure 4 \\
\hline LOC_Os01g14810 & $\begin{array}{l}5 \text {-nucleotidase domain-containing } \\
\text { protein, putative, expressed }\end{array}$ & -1.00083 & -0.18424 & 0.875149 & 0.010906 & -1.047 & 0.3255 & Figure 4 \\
\hline LOC_Os01g15470 & protein kinase, putative, expressed & -1.05266 & -0.219 & 1.141446 & -0.17659 & 0.11725 & 0.81305 & Figure 4 \\
\hline LOC_Os01g19150 & $\begin{array}{l}\text { CGMC_GSK.3 - CGMC includes } \\
\text { CDA, MAPK, GSK3, and CLKC } \\
\text { kinases, expressed }\end{array}$ & -0.97823 & -0.43121 & 1.46745 & -0.01421 & -0.1275 & 0.23955 & Figure 4 \\
\hline LOC_Os01g24750 & $\begin{array}{l}\text { Ser/Thr protein phosphatase family } \\
\text { protein, putative, expressed }\end{array}$ & -0.68218 & -0.36161 & 0.885727 & 0.312546 & 0.31625 & 1.08105 & Figure 4 \\
\hline LOC_Os01g28450 & $\begin{array}{l}\text { SCP-like extracellular protein, } \\
\text { expressed }\end{array}$ & 0.372053 & 1.61947 & 0.914662 & 2.037198 & 4.517 & 0.8253 & Figure 4 \\
\hline LOC_Os01g35330 & $\begin{array}{l}\text { circumsporozoite protein precursor, } \\
\text { putative, expressed }\end{array}$ & -0.34795 & 1.918976 & 1.511377 & & & & Figure 4 \\
\hline LOC_Os01g36950 & N-rich protein, putative, expressed & -0.98642 & 0.310588 & 1.518618 & -0.17178 & 0.281125 & 1.0989 & Figure 4 \\
\hline LOC_Os01g37050 & $\begin{array}{l}\text { ribonuclease III domain protein, } \\
\text { putative, expressed }\end{array}$ & -0.60312 & -0.42046 & 1.263314 & 0.301193 & -1.75224 & 0.1247 & Figure 4 \\
\hline LOC_Os01g37910 & $\begin{array}{l}\text { vacuolar-processing enzyme } \\
\text { precursor, putative, expressed }\end{array}$ & -1.34885 & -0.50324 & 1.990398 & 0.193102 & -1.02125 & -1.1582 & Figure 4 \\
\hline LOC_Os01g38650 & expressed protein & 0.646583 & 2.223721 & 1.45609 & 6.433319 & -0.15985 & -0.2508 & Figure 4 \\
\hline LOC_Os01g42260 & $\begin{array}{l}\text { transcriptional corepressor } \\
\text { LEUNIG, putative, expressed }\end{array}$ & -0.76208 & -0.0509 & 1.035176 & 0.045065 & 0.055 & -0.2768 & Figure 4 \\
\hline LOC_Os01g48930 & $\begin{array}{l}\text { splicing factor-related, putative, } \\
\text { expressed }\end{array}$ & -0.62469 & -0.62635 & 1.411129 & 0.284588 & -0.83453 & 0.3147 & Figure 4 \\
\hline LOC_Os01g53350 & $\begin{array}{l}\text { anthocyanidin } \\
5,3 \text {-O-glucosyltransferase, putative, } \\
\text { expressed }\end{array}$ & -0.93493 & 0.350547 & 1.431636 & 0.634006 & 0.6167 & -0.33065 & Figure 4 \\
\hline LOC_Os01g55870 & $\begin{array}{l}\text { chorismate mutase, chloroplast } \\
\text { precursor, putative, expressed }\end{array}$ & -0.39654 & 0.776814 & 1.198372 & 0.083726 & 0.4675 & 0.94185 & Figure 4 \\
\hline LOC_Os01g58100 & $\begin{array}{l}\text { polyphenol oxidase, putative, } \\
\text { expressed }\end{array}$ & -0.00841 & 1.669244 & 1.401254 & 1.460684 & 0.215975 & & Figure 4 \\
\hline LOC_Os01g58580 & $\begin{array}{l}\text { ICE-like protease } \mathrm{p} 20 \text { domain } \\
\text { containing protein, putative, } \\
\text { expressed }\end{array}$ & -0.82197 & -0.41204 & 1.178699 & 0.003101 & 0.563063 & -0.39125 & Figure 4 \\
\hline LOC_Os01g62460 & $\begin{array}{l}\text { ZOS1-16 - C2H2 zinc finger } \\
\text { protein, expressed }\end{array}$ & -0.77967 & -0.11553 & 0.9173 & 0.325713 & -1.50676 & 0.5238 & Figure 4 \\
\hline LOC_Os01g64110 & $\begin{array}{l}\text { glycosyl hydrolase, putative, } \\
\text { expressed }\end{array}$ & -0.85731 & 0.193286 & 0.612443 & 2.460338 & 0.701125 & -0.01565 & Figure 4 \\
\hline LOC_Os01g64660 & $\begin{array}{l}\text { fructose-1,6-bisphosphatase, } \\
\text { putative, expressed }\end{array}$ & -0.82458 & -1.66019 & 0.973493 & -0.30016 & -2.32073 & -0.9129 & Figure 4 \\
\hline LOC_Os01g64840 & $\begin{array}{l}\text { aspartic proteinase nepenthesin-1 } \\
\text { precursor, putative, expressed }\end{array}$ & 0.637163 & 1.506497 & 0.868187 & -0.03436 & 0.02125 & & Figure 4 \\
\hline LOC_Os01g65900 & $\begin{array}{l}\text { chitin-inducible } \\
\text { gibberellin-responsive protein, } \\
\text { putative, expressed }\end{array}$ & -0.82484 & -0.0625 & 0.808025 & 0.157345 & 0.528 & 1.02565 & Figure 4 \\
\hline LOC_Os01g69050 & $\begin{array}{l}\text { lysine ketoglutarate reductase } \\
\text { trans-splicing related } 1 \text {, putative, } \\
\text { expressed }\end{array}$ & -0.68127 & 0.29725 & 0.876405 & -0.07882 & -0.12683 & & Figure 4 \\
\hline LOC_Os01g70390 & expressed protein & 1.405615 & 1.87148 & 1.243578 & 0.023805 & 0.457775 & -0.04995 & Figure 4 \\
\hline LOC_Os01g71350 & $\begin{array}{l}\text { glycosyl hydrolases family } 17 \text {, } \\
\text { putative, expressed }\end{array}$ & 0.500127 & 0.652049 & 1.205307 & 0.593943 & 1.642625 & 0.5571 & Figure 4 \\
\hline LOC_Os01g71770 & $\begin{array}{l}\text { RNA recognition motif containing } \\
\text { protein, putative, expressed }\end{array}$ & -0.69017 & 0.030101 & 1.081014 & -0.00193 & 0.372 & -0.1018 & Figure 4 \\
\hline LOC_Os01g72370 & $\begin{array}{l}\text { helix-loop-helix DNA-binding } \\
\text { domain containing protein, } \\
\text { expressed }\end{array}$ & -1.75644 & -0.69859 & 0.646425 & 0.02924 & -1.66145 & -0.0425 & Figure 4 \\
\hline LOC_Os01g73500 & expressed protein & -0.59881 & 0.980304 & 1.198605 & 0.769216 & 0.429038 & -0.57925 & Figure 4 \\
\hline
\end{tabular}




\begin{tabular}{|c|c|c|c|c|c|c|c|c|}
\hline LOC_Os02g01150 & $\begin{array}{l}\text { erythronate-4-phosphate } \\
\text { dehydrogenase domain containing } \\
\text { protein, expressed }\end{array}$ & -0.77905 & -0.94952 & 0.976393 & \#\#\#\#\#\#\# & -2.84 & 0.2955 & Figure 4 \\
\hline LOC_Os02g02120 & $\begin{array}{l}\text { OsWAK11 - OsWAK receptor-like } \\
\text { protein kinase, expressed }\end{array}$ & -1.13558 & 0.98523 & 0.673381 & 0.413338 & -0.05999 & & Figure 4 \\
\hline LOC_Os02g05710 & expressed protein & -0.82247 & -0.46327 & 1.091058 & -0.1026 & 0.46945 & 0.43365 & Figure 4 \\
\hline LOC_Os02g06640 & $\begin{array}{l}\text { ubiquitin family protein, putative, } \\
\text { expressed }\end{array}$ & -1.06372 & 0.693782 & 0.609578 & -0.02649 & 0.853875 & 0.19055 & Figure 4 \\
\hline LOC_Os02g08080 & expressed protein & 0.539012 & 1.241269 & 0.799832 & -0.16171 & 0.058413 & -0.21445 & Figure 4 \\
\hline LOC_Os02g08100 & $\begin{array}{l}\text { AMP-binding domain containing } \\
\text { protein, expressed }\end{array}$ & -0.03591 & 0.857866 & 0.696769 & -0.22574 & 0.36825 & 2.4647 & Figure 4 \\
\hline LOC_Os02g08120 & $\begin{array}{l}\text { calmodulin binding protein, } \\
\text { putative, expressed }\end{array}$ & -0.83634 & -0.04884 & 0.974548 & 0.068132 & -0.15166 & -0.0205 & Figure 4 \\
\hline LOC_Os02g10700 & $\begin{array}{l}\text { OsFBL7 - F-box domain and LRR } \\
\text { containing protein, expressed }\end{array}$ & -1.00121 & 0.261725 & 1.108338 & 1.086723 & -0.41813 & -0.04035 & Figure 4 \\
\hline LOC_Os02g12480 & expressed protein & -0.80299 & 0.228533 & 1.090202 & -0.08447 & -0.34988 & 1.22825 & Figure 4 \\
\hline LOC_Os02g13840 & citrate synthase, putative, expressed & -0.74749 & -0.32077 & 1.245042 & 0.123813 & 1.427 & -0.1888 & Figure 4 \\
\hline LOC_Os02g 32110 & $\begin{array}{l}\text { exostosin family domain containing } \\
\text { protein, expressed }\end{array}$ & -0.60211 & -0.08222 & 1.252702 & & & & Figure 4 \\
\hline LOC_Os02g33330 & expressed protein & -0.08634 & 1.878022 & 0.820267 & -0.15051 & 2.2025 & 1.2295 & Figure 4 \\
\hline LOC_Os02g33820 & $\begin{array}{l}\text { abscisic stress-ripening, putative, } \\
\text { expressed }\end{array}$ & 0.372016 & 0.879995 & 0.797212 & -0.0076 & 0.110625 & 0.65515 & Figure 4 \\
\hline LOC_Os02g35039 & $\begin{array}{l}\text { NAD dependent } \\
\text { epimerase/dehydratase family } \\
\text { protein, putative, expressed }\end{array}$ & -0.92128 & 0.047614 & 1.146637 & -0.03667 & 0.17125 & -0.0425 & Figure 4 \\
\hline LOC_Os02g36140 & $\begin{array}{l}\text { terpene synthase, putative, } \\
\text { expressed }\end{array}$ & -0.2034 & 1.102211 & 0.62184 & 0.529439 & 2.143238 & 0.33275 & Figure 4 \\
\hline LOC_Os02g39160 & $\begin{array}{l}\text { hydroxymethylbutenyl } \\
\text { 4-diphosphate synthase, putative, } \\
\text { expressed }\end{array}$ & -0.61911 & 0.433745 & 1.652625 & -0.14289 & 0.769 & 1.73225 & Figure 4 \\
\hline LOC_Os02g39790 & $\begin{array}{l}\text { CPuORF9 - conserved peptide } \\
\text { uORF-containing transcript, } \\
\text { expressed }\end{array}$ & -0.9079 & 0.637574 & 1.993135 & 0.206664 & 0.619875 & 0.0627 & Figure 4 \\
\hline LOC_Os02g43360 & $\begin{array}{l}\text { cytochrome b5-like Heme/Steroid } \\
\text { binding domain containing protein, } \\
\text { expressed }\end{array}$ & -0.29904 & 0.62055 & 1.187221 & -0.06016 & 0.71975 & 1.3644 & Figure 4 \\
\hline LOC_Os02g43860 & $\begin{array}{l}\text { amino acid permease, putative, } \\
\text { expressed }\end{array}$ & -1.04365 & -0.31184 & 1.412509 & 0.021672 & 0.488375 & 0.11125 & Figure 4 \\
\hline LOC_Os02g44240 & expressed protein & 0.80848 & 1.184147 & 1.044616 & -0.02829 & 0.066163 & & Figure 4 \\
\hline LOC_Os02g44260 & $\begin{array}{l}\text { zinc-binding protein, putative, } \\
\text { expressed }\end{array}$ & 0.961141 & 1.759344 & 1.100723 & & & & Figure 4 \\
\hline LOC_Os02g47510 & $\begin{array}{l}\text { 9-cis-epoxycarotenoid dioxygenase } \\
\text { 1, chloroplast precursor, putative, } \\
\text { expressed }\end{array}$ & -0.8896 & -0.71182 & 0.943963 & -0.11318 & -1.44409 & & Figure 4 \\
\hline LOC_Os02g48000 & $\begin{array}{l}\text { TBC domain containing protein, } \\
\text { expressed }\end{array}$ & -0.88525 & -0.01541 & 0.754247 & -0.01039 & 1.198638 & 0.18435 & Figure 4 \\
\hline LOC_Os02g48770 & $\begin{array}{l}\text { SAM dependent carboxyl } \\
\text { methyltransferase, putative, } \\
\text { expressed }\end{array}$ & -0.00182 & 1.239066 & 1.461013 & 0.692851 & 3.978388 & 0.36415 & Figure 4 \\
\hline LOC_Os02g48964 & $\begin{array}{l}\text { WD-40 repeat family protein, } \\
\text { putative, expressed }\end{array}$ & -0.79626 & -0.09659 & 0.652761 & 0.112406 & 0.171838 & 0.91785 & Figure 4 \\
\hline LOC_Os02g50360 & nicalin, putative, expressed & -0.8684 & 0.183329 & 0.718323 & 0.040078 & -0.03463 & -0.0378 & Figure 4 \\
\hline LOC_Os02g53700 & $\begin{array}{l}\text { DENN domain containing protein, } \\
\text { expressed }\end{array}$ & -0.72789 & -0.17854 & 1.068998 & -0.31943 & -0.13513 & 0.22165 & Figure 4 \\
\hline
\end{tabular}




\begin{tabular}{|c|c|c|c|c|c|c|c|c|}
\hline LOC_Os02g54730 & $\begin{array}{l}\text { transmembrane amino acid } \\
\text { transporter protein, putative, } \\
\text { expressed }\end{array}$ & -0.805 & -0.42083 & 0.812236 & -0.20652 & -1.47428 & -0.3275 & Figure 4 \\
\hline LOC_Os02g57180 & $\begin{array}{l}\text { NADH dehydrogenase } 1 \text { alpha } \\
\text { subcomplex subunit } 9 \text {,mitochondrial } \\
\text { precursor, putative, expressed }\end{array}$ & -0.77687 & -0.02834 & 1.260289 & -0.10682 & 0.365613 & -0.06855 & Figure 4 \\
\hline LOC_Os02g57410 & $\begin{array}{l}\text { OTU-like cysteine protease family } \\
\text { protein, putative, expressed }\end{array}$ & -0.81021 & -0.42941 & 1.277887 & -0.1184 & 0.14135 & 0.81835 & Figure 4 \\
\hline LOC_Os02g57600 & expressed protein & -0.64718 & -0.00113 & 0.97399 & -0.2612 & 0.738975 & 0.2938 & Figure 4 \\
\hline LOC_Os03g02590 & $\begin{array}{l}\text { peroxisomal biogenesis factor } 11 \text {, } \\
\text { putative, expressed }\end{array}$ & -0.77663 & -0.5884 & 1.276663 & 0.070674 & -1.68225 & -0.0034 & Figure 4 \\
\hline LOC_Os03g03720 & $\begin{array}{l}\text { glyceraldehyde-3-phosphate } \\
\text { dehydrogenase, putative, expressed }\end{array}$ & -1.04445 & -0.38365 & 0.879045 & -0.16586 & -2.554 & 0.42805 & Figure 4 \\
\hline LOC_Os03g03810 & $\begin{array}{l}\text { DEF8 - Defensin and Defensin-like } \\
\text { DEFL family, expressed }\end{array}$ & -0.84973 & 1.581758 & 1.576025 & 0.057248 & 0.516725 & & Figure 4 \\
\hline LOC_Os03g05390 & $\begin{array}{l}\text { Citrate transporter protein, putative, } \\
\text { expressed }\end{array}$ & -0.82271 & -0.27244 & 1.563009 & -0.20723 & -1.681 & -0.1067 & Figure 4 \\
\hline LOC_Os03g05620 & $\begin{array}{l}\text { inorganic phosphate transporter, } \\
\text { putative, expressed }\end{array}$ & -0.87922 & 0.360406 & 0.939645 & 2.454804 & 0.87935 & & Figure 4 \\
\hline LOC_Os03g08170 & $\begin{array}{l}\text { protein kinase APK1B, chloroplast } \\
\text { precursor, putative, expressed }\end{array}$ & -0.22801 & 0.975376 & 0.773161 & 0.006001 & -0.61211 & 1.0178 & Figure 4 \\
\hline LOC_Os03g08999 & dehydrogenase, putative, expressed & 0.084622 & 0.749322 & 1.095651 & 1.052493 & -1.65241 & 0.0579 & Figure 4 \\
\hline LOC_Os03g09250 & $\begin{array}{l}\text { inositol-3-phosphate synthase, } \\
\text { putative, expressed }\end{array}$ & -0.04775 & 0.616271 & 2.408002 & 0.586429 & 1.589625 & -0.25555 & Figure 4 \\
\hline LOC_Os03g 10880 & $\begin{array}{l}\text { BTBN5 - Bric-a-Brac, Tramtrack, } \\
\text { Broad Complex BTB domain with } \\
\text { non-phototropic hypocotyl } 3 \text { NPH3 } \\
\text { and coiled-coil domains, expressed }\end{array}$ & -0.97051 & -1.08046 & 1.26788 & 0.046635 & -1.04508 & & Figure 4 \\
\hline LOC_Os03g 12590 & $\begin{array}{l}\text { coatomer subunit gamma-1, } \\
\text { putative, expressed }\end{array}$ & -0.67976 & 0.263975 & 0.962386 & 0.234857 & 0.865825 & -0.0666 & Figure 4 \\
\hline LOC_Os03g13970 & $\begin{array}{l}\text { 26S proteasome non-ATPase } \\
\text { regulatory subunit } 4 \text {, putative, } \\
\text { expressed }\end{array}$ & -0.63307 & -0.42429 & 1.059866 & -0.13787 & 0.229375 & 0.03735 & Figure 4 \\
\hline LOC_Os03g17380 & expressed protein & 1.14035 & 1.764665 & 0.98704 & & & & Figure 4 \\
\hline LOC_Os03g18850 & $\begin{array}{l}\text { pathogenesis-related Bet v I family } \\
\text { protein, putative, expressed }\end{array}$ & 0.65661 & 1.045877 & 1.113257 & 0.426657 & -4.08613 & & Figure 4 \\
\hline LOC_Os03g19960 & $\begin{array}{l}\text { ATP-dependent RNA helicase, } \\
\text { putative, expressed }\end{array}$ & -0.65439 & -0.29234 & 1.163933 & -0.22722 & -0.01838 & 0.0664 & Figure 4 \\
\hline LOC_Os03g20330 & $\begin{array}{l}\text { VQ domain containing protein, } \\
\text { putative, expressed }\end{array}$ & -0.70253 & 1.104517 & -0.73562 & 2.861238 & -0.75059 & 2.8292 & Figure 4 \\
\hline LOC_Os03g22420 & $\begin{array}{l}\text { AAA-type ATPase family protein, } \\
\text { putative, expressed }\end{array}$ & -0.44322 & 0.667829 & 1.0875 & -0.02093 & 0.284375 & & Figure 4 \\
\hline LOC_Os03g24040 & $\begin{array}{l}\text { seven in absentia protein family } \\
\text { domain containing protein, } \\
\text { expressed }\end{array}$ & 0.637973 & 0.868475 & 0.855166 & & & 0.7346 & Figure 4 \\
\hline LOC_Os03g25070 & $\begin{array}{l}\text { CAMK_CAMK_like.18 - CAMK } \\
\text { includes calcium/calmodulin } \\
\text { depedent protein kinases, expressed }\end{array}$ & -0.6588 & -0.46013 & 1.014203 & -0.13715 & 0.501063 & 0.1929 & Figure 4 \\
\hline LOC_Os03g29190 & PDI, putative, expressed & -0.18225 & 1.172415 & 0.969791 & 1.741026 & 0.366763 & 0.26155 & Figure 4 \\
\hline LOC_Os03g30190 & $\begin{array}{l}\text { retrotransposon protein, putative, } \\
\text { unclassified, expressed }\end{array}$ & 1.353919 & 2.24824 & 1.355825 & & & & Figure 4 \\
\hline LOC_Os03g31300 & $\begin{array}{l}\text { chaperone protein clpB } 1 \text {, putative, } \\
\text { expressed }\end{array}$ & -0.69475 & 0.16005 & 1.388952 & -0.22987 & -0.96638 & -0.0237 & Figure 4 \\
\hline LOC_Os03g32314 & $\begin{array}{l}\text { allene oxide cyclase } 4 \text {, chloroplast } \\
\text { precursor, putative, expressed }\end{array}$ & -0.70565 & -0.00401 & 1.094336 & 0.027076 & 1.53175 & -0.26065 & Figure 4 \\
\hline LOC_Os03g 36750 & cbbY, putative, expressed & -0.8416 & -0.74637 & 0.754195 & 0.09488 & -0.94066 & 0.272 & Figure 4 \\
\hline
\end{tabular}




\begin{tabular}{|c|c|c|c|c|c|c|c|c|}
\hline LOC_Os03g37830 & $\begin{array}{l}\text { potassium transporter, putative, } \\
\text { expressed }\end{array}$ & -0.16712 & 0.866306 & 1.691325 & -0.10637 & -0.18579 & 1.8453 & Figure 4 \\
\hline LOC_Os03g39560 & $\begin{array}{l}\text { retrotransposon protein, putative, } \\
\text { unclassified, expressed }\end{array}$ & 0.520306 & 1.442007 & 0.633289 & & & & Figure 4 \\
\hline LOC_Os03g48660 & $\begin{array}{l}\text { DUF1336 domain containing } \\
\text { protein, expressed }\end{array}$ & 0.052302 & 0.695765 & 0.866108 & 0.023825 & 0.810625 & & Figure 4 \\
\hline LOC_Os03g51910 & $\begin{array}{l}\text { basic helix-loop-helix protein, } \\
\text { putative, expressed }\end{array}$ & -0.32707 & 1.087504 & 0.795232 & 0.714943 & -0.56433 & & Figure 4 \\
\hline LOC_Os03g53520 & expressed protein & -0.69831 & -0.9415 & 1.260336 & -0.36916 & 0.496413 & -0.4574 & Figure 4 \\
\hline LOC_Os03g55540 & $\begin{array}{l}\text { ZOS3-18 - C2H2 zinc finger } \\
\text { protein, expressed }\end{array}$ & -0.70099 & -0.05171 & 1.140078 & 0.889493 & 1.46225 & 2.9079 & Figure 4 \\
\hline LOC_Os03g56280 & $\begin{array}{l}\text { lactate/malate dehydrogenase, } \\
\text { putative, expressed }\end{array}$ & -0.75105 & -0.74289 & 0.892172 & 0.094108 & -2.65425 & -0.0445 & Figure 4 \\
\hline LOC_Os03g56460 & $\begin{array}{l}\text { glucose-6-phosphate isomerase, } \\
\text { putative, expressed }\end{array}$ & -0.83767 & -0.81911 & 1.164797 & -0.12843 & -0.353 & -0.3123 & Figure 4 \\
\hline LOC_Os03g57110 & expressed protein & -0.66752 & -0.26454 & 1.375674 & 0.224606 & 0.0595 & -0.7048 & Figure 4 \\
\hline LOC_Os03g58470 & $\begin{array}{l}\text { retrotransposon protein, putative, } \\
\text { Ty3-gypsy subclass, expressed }\end{array}$ & 0.167802 & 0.647122 & 1.262179 & 0.761888 & -0.32875 & 0.0545 & Figure 4 \\
\hline LOC_Os03g58790 & ATPase, putative, expressed & -0.66516 & 0.747763 & 1.072476 & 2.850385 & 0.992725 & 0.8413 & Figure 4 \\
\hline LOC_Os03g60090 & $\begin{array}{l}\text { methylenetetrahydrofolate } \\
\text { reductase, putative, expressed }\end{array}$ & 0.083086 & 1.138991 & 1.041158 & 0.009448 & 0.51125 & 0.1575 & Figure 4 \\
\hline LOC_Os03g61130 & $\begin{array}{l}\text { phosphoesterase family protein, } \\
\text { putative, expressed }\end{array}$ & -0.89047 & 0.175411 & 1.228094 & -0.36764 & 0.472125 & 0.315 & Figure 4 \\
\hline LOC_Os03g61960 & $\begin{array}{l}2 \mathrm{Fe}-2 \mathrm{~S} \text { iron-sulfur cluster binding } \\
\text { domain containing protein, } \\
\text { expressed }\end{array}$ & 0.228726 & 1.121364 & 0.723668 & -0.00275 & 1.679625 & & Figure 4 \\
\hline LOC_Os03g62200 & $\begin{array}{l}\text { ammonium transporter protein, } \\
\text { putative, expressed }\end{array}$ & -0.11178 & 1.827604 & 0.747954 & 0.648322 & -0.31638 & 2.36805 & Figure 4 \\
\hline LOC_Os04g04040 & expressed protein & -0.04059 & 1.008227 & 0.830286 & & & & Figure 4 \\
\hline LOC_Os04g04050 & expressed protein & 2.09564 & 3.009584 & 2.162603 & & & & Figure 4 \\
\hline LOC_Os04g04440 & $\begin{array}{l}\text { retrotransposon protein, putative, } \\
\text { unclassified }\end{array}$ & 0.178221 & 1.202952 & 0.735868 & & & & Figure 4 \\
\hline LOC_Os04g04540 & $\begin{array}{l}\text { retrotransposon, putative, } \\
\text { centromere-specific, expressed }\end{array}$ & 0.244272 & 1.098164 & 1.062164 & & & & Figure 4 \\
\hline LOC_Os04g12520 & $\begin{array}{l}\text { transposon protein, putative, } \\
\text { unclassified, expressed }\end{array}$ & 0.620964 & 0.895447 & 0.906761 & & & & Figure 4 \\
\hline LOC_Os04g15690 & $\begin{array}{l}\text { DSBA-like thioredoxin domain } \\
\text { containing protein, expressed }\end{array}$ & -1.13414 & 1.034968 & 1.427958 & 1.050473 & 0.002913 & -0.7268 & Figure 4 \\
\hline LOC_Os04g15920 & dehydrogenase, putative, expressed & -0.17264 & 1.196878 & 0.662445 & 0.504846 & 2.102925 & 0.2482 & Figure 4 \\
\hline LOC_Os04g16680 & $\begin{array}{l}\text { fructose-1,6-bisphosphatase, } \\
\text { putative, expressed }\end{array}$ & -0.87423 & -0.83194 & 1.138305 & -0.04861 & -3.19063 & -0.40825 & Figure 4 \\
\hline LOC_Os04g16730 & hypothetical protein & -0.15817 & 0.652854 & 1.025593 & & & & Figure 4 \\
\hline LOC_Os04g24220 & $\begin{array}{l}\text { OsWAK32 - OsWAK receptor-like } \\
\text { protein kinase, expressed }\end{array}$ & -0.3636 & 1.049977 & 0.652823 & 0.571276 & -0.05271 & -0.78515 & Figure 4 \\
\hline LOC_Os04g27340 & $\begin{array}{l}\text { terpene synthase, putative, } \\
\text { expressed }\end{array}$ & -0.20764 & 1.48521 & 0.967139 & & & & Figure 4 \\
\hline LOC_Os04g29790 & $\begin{array}{l}\text { OsWAK40 - OsWAK receptor-like } \\
\text { protein OsWAK-RLP, expressed }\end{array}$ & -0.99643 & 0.529033 & 0.634053 & & & & Figure 4 \\
\hline LOC_Os04g31700 & $\begin{array}{l}\text { methylisocitrate lyase } 2 \text {, putative, } \\
\text { expressed }\end{array}$ & -0.74025 & -0.03289 & 1.161776 & 0.014329 & 0.072388 & & Figure 4 \\
\hline LOC_Os04g32020 & $\begin{array}{l}\text { 2-oxoglutarate dehydrogenase E1 } \\
\text { component, mitochondrial } \\
\text { precursor, putative, expressed }\end{array}$ & -0.72045 & 0.237726 & 1.593301 & 0.165379 & 0.53325 & 0.0699 & Figure 4 \\
\hline LOC_Os04g32950 & $\begin{array}{l}\text { calreticulin precursor protein, } \\
\text { putative, expressed }\end{array}$ & -1.00253 & 0.263849 & 1.177382 & 0.432092 & 1.2905 & & Figure 4 \\
\hline
\end{tabular}




\begin{tabular}{|c|c|c|c|c|c|c|c|c|}
\hline LOC_Os04g33190 & $\begin{array}{l}\text { AMP-binding enzyme, putative, } \\
\text { expressed }\end{array}$ & -0.17149 & 0.638145 & 1.464633 & 0.416425 & 0.651875 & & Figure 4 \\
\hline LOC_Os04g37619 & $\begin{array}{l}\text { zeaxanthin epoxidase, chloroplast } \\
\text { precursor, putative, expressed }\end{array}$ & -0.63111 & -0.10812 & 1.079638 & -0.3939 & 0.43325 & & Figure 4 \\
\hline LOC_Os $04 \mathrm{~g} 42470$ & $\begin{array}{l}\text { regulatory subunit, putative, } \\
\text { expressed }\end{array}$ & -0.92728 & -0.92712 & 1.813929 & -0.21151 & -0.50775 & -0.19955 & Figure 4 \\
\hline LOC_Os04g43070 & $\begin{array}{l}\text { ammonium transporter protein, } \\
\text { putative, expressed }\end{array}$ & 0.080032 & 0.658318 & 1.296181 & 0.046657 & -1.751 & 1.0725 & Figure 4 \\
\hline LOC_Os04g49194 & $\begin{array}{l}\text { naringenin,2-oxoglutarate } \\
\text { 3-dioxygenase, putative, expressed }\end{array}$ & -0.83956 & 0.663057 & 0.39834 & 0.941388 & 0.88985 & 0.20455 & Figure 4 \\
\hline LOC_Os04g49210 & $\begin{array}{l}\text { naringenin,2-oxoglutarate } \\
\text { 3-dioxygenase, putative, expressed }\end{array}$ & -0.31 & 1.544026 & 0.818011 & 3.917561 & 0.635925 & -0.27815 & Figure 4 \\
\hline LOC_Os04g51400 & $\begin{array}{l}\text { zinc finger, } \mathrm{C} 3 \mathrm{HC} 4 \text { type domain } \\
\text { containing protein, expressed }\end{array}$ & -0.91767 & -0.73336 & 1.30017 & 0.1439 & -1.389 & 0.975 & Figure 4 \\
\hline LOC_Os04g53810 & $\begin{array}{l}\text { leucoanthocyanidin reductase, } \\
\text { putative, expressed }\end{array}$ & -0.88053 & 0.053729 & 1.584638 & 1.544892 & 0.797013 & 0.5832 & Figure 4 \\
\hline LOC_Os04g55710 & $\begin{array}{l}\text { transposon protein, putative, } \\
\text { unclassified, expressed }\end{array}$ & -1.09985 & 0.281609 & 0.745361 & 2.24599 & -2.08654 & 0.53535 & Figure 4 \\
\hline LOC_Os04g55850 & nuclease PA3, putative, expressed & 0.074395 & 0.884555 & 0.676601 & -0.12294 & 1.0904 & 0.05255 & Figure 4 \\
\hline LOC_Os04g57200 & $\begin{array}{l}\text { heavy metal transport/detoxification } \\
\text { protein, putative, expressed }\end{array}$ & -0.93951 & 0.368701 & 1.021466 & 1.620669 & 0.24285 & & Figure 4 \\
\hline LOC_Os04g57300 & $\begin{array}{l}\text { phosphatidylinositol 3- and 4-kinase } \\
\text { family protein, putative, expressed }\end{array}$ & -0.76254 & -0.66953 & 1.321861 & 0.015864 & -0.17138 & -0.06725 & Figure 4 \\
\hline LOC_Os04g57750 & $\begin{array}{l}\text { plastocyanin-like domain containing } \\
\text { protein, putative, expressed }\end{array}$ & 1.574197 & 1.691384 & 0.945251 & -0.03242 & 0.150838 & 0.38485 & Figure 4 \\
\hline LOC_Os04g58270 & expressed protein & 0.496199 & 1.067049 & 1.044962 & & & & Figure 4 \\
\hline LOC_Os04g58330 & expressed protein & 0.009048 & 0.624041 & 1.255325 & 0.233994 & 0.1294 & 0.8048 & Figure 4 \\
\hline LOC_Os05g01030 & $\begin{array}{l}\text { phospholipid-transporting ATPase, } \\
\text { putative, expressed }\end{array}$ & 0.77225 & 1.276122 & 1.511973 & 0.475761 & 2.28595 & 1.8171 & Figure 4 \\
\hline LOC_Os05g01140 & $\begin{array}{l}\text { methyltransferase, putative, } \\
\text { expressed }\end{array}$ & 0.162597 & 1.245963 & 1.7746 & 0.230434 & -0.01346 & 0.76925 & Figure 4 \\
\hline LOC_Os05g04630 & $\begin{array}{l}\text { retrotransposon protein, putative, } \\
\text { SINE subclass, expressed }\end{array}$ & -0.66538 & -0.31187 & 1.266295 & 0.008786 & 0.37675 & -0.19165 & Figure 4 \\
\hline LOC_Os05g05020 & expressed protein & -0.81052 & 0.8558 & 1.768554 & 0.010736 & -0.02603 & 1.8458 & Figure 4 \\
\hline LOC_Os05g05030 & expressed protein & -0.87545 & 0.674762 & 1.722902 & 0.333969 & -0.55819 & -0.6012 & Figure 4 \\
\hline LOC_Os05g05940 & $\begin{array}{l}\text { stress-related protein, putative, } \\
\text { expressed }\end{array}$ & -0.94015 & -0.05886 & 1.063594 & 0.151245 & 0.28675 & & Figure 4 \\
\hline LOC_Os05g06260 & $\begin{array}{l}\text { Spc97 / Spc98 family protein, } \\
\text { putative, expressed }\end{array}$ & 0.294082 & 0.999835 & 0.65416 & -0.13482 & 0.142975 & & Figure 4 \\
\hline LOC_Os05g06350 & $\begin{array}{l}\text { importin subunit alpha, putative, } \\
\text { expressed }\end{array}$ & -0.79288 & 0.317946 & 1.042954 & -0.15193 & 0.208625 & 0.227 & Figure 4 \\
\hline LOC_Os05g19910 & $\begin{array}{l}\text { transferase family protein, putative, } \\
\text { expressed }\end{array}$ & -0.19814 & 1.207265 & 0.852967 & 0.087206 & -0.7305 & 0.47465 & Figure 4 \\
\hline LOC_Os05g30500 & expressed protein & -1.02089 & 1.441208 & 0.560114 & 5.574205 & -0.50921 & & Figure 4 \\
\hline LOC_Os05g31140 & $\begin{array}{l}\text { glycosyl hydrolases family } 17, \\
\text { putative, expressed }\end{array}$ & -0.78844 & -0.7469 & 1.858892 & 0.32171 & 1.235625 & 0.39965 & Figure 4 \\
\hline LOC_Os05g 33570 & $\begin{array}{l}\text { pyruvate, phosphate dikinase, } \\
\text { chloroplast precursor, putative, } \\
\text { expressed }\end{array}$ & 0.061504 & 0.836358 & 0.981813 & -0.05522 & 0.56975 & 1.3279 & Figure 4 \\
\hline LOC_Os05g 33610 & expressed protein & -0.67743 & -0.55813 & 1.020504 & -0.28531 & 0.1895 & 0.4506 & Figure 4 \\
\hline LOC_Os05g33710 & $\begin{array}{l}\text { WD domain, G-beta repeat domain } \\
\text { containing protein, expressed }\end{array}$ & -0.89961 & -0.43418 & 0.880772 & -0.13261 & 0.0275 & -0.2724 & Figure 4 \\
\hline LOC_Os05g 34270 & $\begin{array}{l}\text { inactive receptor kinase At1g27190 } \\
\text { precursor, putative, expressed }\end{array}$ & -1.01778 & 0.820989 & 0.305172 & 0.811334 & 0.288 & 1.0468 & Figure 4 \\
\hline LOC_Os05g40270 & expressed protein & -0.58008 & 0.814495 & 0.644073 & -0.15324 & -1.21163 & -0.2552 & Figure 4 \\
\hline
\end{tabular}




\begin{tabular}{|c|c|c|c|c|c|c|c|c|}
\hline LOC_Os05g43170 & $\begin{array}{l}\text { calreticulin precursor protein, } \\
\text { putative, expressed }\end{array}$ & -1.29567 & -0.09876 & 0.986462 & 0.707302 & 0.02175 & 0.48415 & Figure 4 \\
\hline LOC_Os05g46020 & WRKY7, expressed & -0.76488 & 0.8658 & 0.015174 & 2.482018 & 1.146363 & & Figure 4 \\
\hline LOC_Os05g48210 & expressed protein & -0.75753 & 0.981228 & 0.584407 & 0.772179 & 1.087 & 2.1097 & Figure 4 \\
\hline LOC_Os05g50100 & expressed protein & 0.176906 & 1.068084 & 0.785398 & 1.227359 & 2.032625 & 3.3336 & Figure 4 \\
\hline LOC_Os06g03580 & $\begin{array}{l}\text { zinc RING finger protein, putative, } \\
\text { expressed }\end{array}$ & -0.6775 & 0.916111 & -0.4471 & 1.465421 & -0.12158 & 1.83885 & Figure 4 \\
\hline LOC_Os06g03600 & $\begin{array}{l}\text { transcriptional corepressor SEUSS, } \\
\text { putative, expressed }\end{array}$ & -0.63108 & -0.49653 & 1.196438 & -0.11099 & -0.19363 & 0.1537 & Figure 4 \\
\hline LOC_Os06g06580 & expressed protein & -0.60958 & -0.12319 & 1.102104 & 0.098034 & 0.028713 & & Figure 4 \\
\hline LOC_Os06g09370 & PTF1, putative, expressed & -0.60589 & 0.60267 & 1.120514 & 0.10838 & 0.94565 & 0.7746 & Figure 4 \\
\hline LOC_Os06g15360 & $\begin{array}{l}\text { RAD23 DNA repair protein, } \\
\text { putative, expressed }\end{array}$ & -0.71919 & -0.27624 & 0.804288 & 0.122697 & 0.259625 & 0.0224 & Figure 4 \\
\hline LOC_Os06g15430 & expressed protein & 0.386732 & 2.661183 & 2.884091 & 0.043752 & 0.063938 & & Figure 4 \\
\hline LOC_Os06g15730 & expressed protein & 0.0023 & 0.906599 & 1.025873 & 0.213153 & -2.14595 & & Figure 4 \\
\hline LOC_Os06g15990 & $\begin{array}{l}\text { aldehyde dehydrogenase, putative, } \\
\text { expressed }\end{array}$ & -0.91169 & -0.41502 & 0.807655 & 0.258009 & 0.485 & -0.12365 & Figure 4 \\
\hline LOC_Os06g24980 & hypothetical protein & 0.186696 & 0.858061 & 0.762143 & & & & Figure 4 \\
\hline LOC_Os06g28600 & expressed protein & 1.825798 & 1.993264 & 1.544256 & & & & Figure 4 \\
\hline LOC_Os06g29730 & $\begin{array}{l}\text { RALFL28 - Rapid ALkalinization } \\
\text { Factor RALF family protein } \\
\text { precursor, expressed }\end{array}$ & -2.20891 & 1.638874 & 2.282938 & 3.207274 & 0.777488 & 0.08745 & Figure 4 \\
\hline LOC_Os06g29740 & $\begin{array}{l}\text { OsFBX197 - F-box domain } \\
\text { containing protein, expressed }\end{array}$ & -1.38033 & 1.581222 & 1.558929 & & & & Figure 4 \\
\hline LOC_Os06g29770 & hypothetical protein & -0.36163 & 1.284454 & 0.819666 & & & & Figure 4 \\
\hline LOC_Os06g34730 & expressed protein & 0.147477 & 1.463842 & 1.284309 & 0.596326 & 3.046875 & -0.5551 & Figure 4 \\
\hline LOC_Os06g 36840 & $\begin{array}{l}\text { cysteine synthase, putative, } \\
\text { expressed }\end{array}$ & -0.63889 & -0.84289 & 0.883105 & -0.34688 & -1.13881 & -0.40255 & Figure 4 \\
\hline LOC_Os06g40360 & $\begin{array}{l}\text { OsFBL30 - F-box domain and LRR } \\
\text { containing protein, expressed }\end{array}$ & -0.94474 & 0.441776 & 0.788987 & 0.490685 & -0.49463 & -0.2796 & Figure 4 \\
\hline LOC_Os06g47350 & $\begin{array}{l}\text { RNA polymerase I specific } \\
\text { transcription initiation factor RRN3 } \\
\text { family protein, putative, expressed }\end{array}$ & -0.90071 & -0.16899 & 1.138781 & 0.12431 & -0.3846 & -0.15375 & Figure 4 \\
\hline LOC_Os06g49040 & $\begin{array}{l}\text { Myb-like DNA-binding domain } \\
\text { containing protein, putative, } \\
\text { expressed }\end{array}$ & -0.69809 & -0.21604 & 1.70527 & -0.63941 & -0.31763 & -0.2834 & Figure 4 \\
\hline LOC_Os06g50380 & $\begin{array}{l}\text { protein phosphatase } 2 \mathrm{C} \text {, putative, } \\
\text { expressed }\end{array}$ & -0.75351 & -0.15734 & 1.32197 & -0.13594 & -0.09875 & 0.4257 & Figure 4 \\
\hline LOC_Os07g01550 & $\begin{array}{l}\text { leucine rich repeat domain } \\
\text { containing protein, putative, } \\
\text { expressed }\end{array}$ & -0.73593 & 0.08566 & 1.084281 & -0.48409 & 0.130425 & 0.13765 & Figure 4 \\
\hline LOC_Os07g01760 & $\begin{array}{l}\text { aminotransferase, classes I and II, } \\
\text { domain containing protein, } \\
\text { expressed }\end{array}$ & -1.08046 & -0.94311 & 1.259548 & 0.090304 & -2.26738 & -0.52445 & Figure 4 \\
\hline LOC_Os07g03900 & $\begin{array}{l}\text { lectin-like receptor kinase, putative, } \\
\text { expressed }\end{array}$ & -0.17543 & 0.938464 & 0.828874 & -0.01753 & -0.0816 & & Figure 4 \\
\hline LOC_Os07g04180 & $\begin{array}{l}\text { amino acid transporter, putative, } \\
\text { expressed }\end{array}$ & -1.1317 & -0.21078 & 1.609952 & -0.15372 & -1.60215 & 0.2762 & Figure 4 \\
\hline LOC_Os07g05820 & $\begin{array}{l}\text { hydroxyacid oxidase } 1 \text {, putative, } \\
\text { expressed }\end{array}$ & -1.03291 & -0.94306 & 1.330001 & 0.206442 & -2.524 & 1.38545 & Figure 4 \\
\hline LOC_Os07g06830 & $\begin{array}{l}\text { gibberellin receptor GID1L2, } \\
\text { putative, expressed }\end{array}$ & -0.62594 & 0.480929 & 0.870572 & 1.181186 & 2.158875 & 2.1187 & Figure 4 \\
\hline LOC_Os07g09010 & nodulin, putative, expressed & -0.52245 & 0.977042 & 0.654159 & 0.980485 & 0.963663 & 0.08165 & Figure 4 \\
\hline LOC_Os07g09320 & $\begin{array}{l}\text { FHA domain containing protein, } \\
\text { putative, expressed }\end{array}$ & -0.61725 & -0.21661 & 0.886505 & 0.116204 & -0.1642 & 0.0504 & Figure 4 \\
\hline LOC_Os07g16600 & expressed protein & 2.277472 & 3.201661 & 2.064889 & 0.38583 & -0.27873 & -0.13045 & Figure 4 \\
\hline
\end{tabular}




\begin{tabular}{|c|c|c|c|c|c|c|c|c|}
\hline LOC_Os07g23120 & expressed protein & -0.3016 & 0.742393 & 2.011276 & 1.943656 & -3.23474 & -0.5672 & Figure 4 \\
\hline LOC_Os07g26490 & $\begin{array}{l}\text { ankyrin repeat domain containing } \\
\text { protein, expressed }\end{array}$ & -0.76434 & 0.081198 & 1.353311 & 0.035187 & 0.29975 & 0.0046 & Figure 4 \\
\hline LOC_Os07g28480 & $\begin{array}{l}\text { glutathione S-transferase, putative, } \\
\text { expressed }\end{array}$ & -0.81227 & -1.14276 & 1.079337 & 0.270151 & -1.9196 & -0.66315 & Figure 4 \\
\hline LOC_Os07g29290 & $\begin{array}{l}\text { expansin precursor, putative, } \\
\text { expressed }\end{array}$ & -0.16569 & 0.663386 & 0.914085 & -0.55364 & 1.402375 & -0.08705 & Figure 4 \\
\hline LOC_Os07g35560 & $\begin{array}{l}\text { glucan endo-1,3-beta-glucosidase } \\
\text { precursor, putative, expressed }\end{array}$ & -1.21901 & 0.426135 & 1.39239 & 1.298103 & 0.991363 & -0.2355 & Figure 4 \\
\hline LOC_Os07g36470 & $\begin{array}{l}\text { vacuolar ATP synthase subunit } \mathrm{H} \text {, } \\
\text { putative, expressed }\end{array}$ & -0.77629 & -0.14436 & 1.333521 & & & 0.30085 & Figure 4 \\
\hline LOC_Os07g 37320 & $\begin{array}{l}\text { transporter family protein, putative, } \\
\text { expressed }\end{array}$ & -0.76722 & -0.46646 & 0.825372 & 0.491275 & -0.0995 & & Figure 4 \\
\hline LOC_Os07g39560 & $\begin{array}{l}\text { RNA recognition motif containing } \\
\text { protein, putative, expressed }\end{array}$ & -0.86229 & -0.34553 & 0.800235 & -0.09132 & 0.819075 & 0.6439 & Figure 4 \\
\hline LOC_Os07g41410 & $\begin{array}{l}\text { EGG APPARATUS-1, putative, } \\
\text { expressed }\end{array}$ & -2.18787 & 0.911142 & 1.147621 & 2.57855 & -1.74084 & & Figure 4 \\
\hline LOC_Os07g45570 & expressed protein & -0.64508 & 0.765675 & 1.906607 & 0.848385 & 0.68 & 0.2768 & Figure 4 \\
\hline LOC_Os07g46370 & $\begin{array}{l}\text { WD domain, G-beta repeat domain } \\
\text { containing protein, expressed }\end{array}$ & -0.61043 & 0.105536 & 0.914468 & 0.036131 & 0.19775 & -0.012 & Figure 4 \\
\hline LOC_Os07g46460 & $\begin{array}{l}\text { ferredoxin-dependent glutamate } \\
\text { synthase, chloroplast precursor, } \\
\text { putative, expressed }\end{array}$ & -1.00177 & -0.09447 & 1.698099 & -0.24174 & -1.52268 & -0.1921 & Figure 4 \\
\hline LOC_Os07g46520 & $\begin{array}{l}\text { rhythmically expressed gene } 2 \\
\text { protein, putative, expressed }\end{array}$ & 0.461344 & 0.699831 & 1.231311 & -0.32307 & -0.72829 & & Figure 4 \\
\hline LOC_Os07g46920 & $\begin{array}{l}\text { sex determination protein } \\
\text { tasselseed-2, putative, expressed }\end{array}$ & 0.362614 & 1.437106 & 1.370873 & -0.04603 & 0.1293 & & Figure 4 \\
\hline LOC_Os07g47150 & expressed protein & -0.25394 & 0.892945 & 1.697645 & -0.38384 & 0.252225 & 0.1655 & Figure 4 \\
\hline LOC_Os07g48020 & $\begin{array}{l}\text { peroxidase precursor, putative, } \\
\text { expressed }\end{array}$ & -0.39394 & 1.415791 & 2.109258 & 1.746237 & -1.78905 & -1.23325 & Figure 4 \\
\hline LOC_Os07g48050 & $\begin{array}{l}\text { peroxidase precursor, putative, } \\
\text { expressed }\end{array}$ & -0.16103 & 1.9694 & 2.452248 & 2.278653 & -0.90539 & & Figure 4 \\
\hline LOC_Os07g48100 & $\begin{array}{l}\text { CAMK_KIN1/SNF1/Nim1_like.31 } \\
\text { - CAMK includes } \\
\text { calcium/calmodulin depedent } \\
\text { protein kinases, expressed }\end{array}$ & -0.56661 & 0.766023 & 1.076177 & -0.45404 & -0.11138 & 0.12765 & Figure 4 \\
\hline LOC_Os08g02230 & $\begin{array}{l}\text { FAD-binding and arabino-lactone } \\
\text { oxidase domains containing protein, } \\
\text { putative, expressed }\end{array}$ & -0.02447 & 1.174869 & 0.747826 & 1.784682 & 2.55875 & 0.6397 & Figure 4 \\
\hline LOC_Os08g03290 & $\begin{array}{l}\text { glyceraldehyde-3-phosphate } \\
\text { dehydrogenase, putative, expressed }\end{array}$ & -0.68219 & 0.027479 & 1.727328 & -0.15612 & 1.012 & -0.40285 & Figure 4 \\
\hline LOC_Os08g04500 & $\begin{array}{l}\text { terpene synthase, putative, } \\
\text { expressed }\end{array}$ & -0.26414 & 1.487079 & 1.611447 & 0.828786 & -0.78225 & & Figure 4 \\
\hline LOC_Os08g06010 & $\begin{array}{l}\text { transporter, major facilitator family, } \\
\text { putative, expressed }\end{array}$ & -0.40771 & 0.62253 & 1.421575 & -0.28354 & -0.69498 & -0.99025 & Figure 4 \\
\hline LOC_Os08g07080 & $\begin{array}{l}\text { terpene synthase, putative, } \\
\text { expressed }\end{array}$ & -1.02679 & 3.70212 & 3.052742 & 1.262063 & 0.144363 & & Figure 4 \\
\hline LOC_Os08g07330 & RGH1A, putative, expressed & -0.5925 & 0.636951 & 0.912574 & 0.255114 & 0.179588 & & Figure 4 \\
\hline LOC_Os08g 12750 & $\begin{array}{l}\text { serine/threonine-protein kinase } \\
\text { HT1, putative, expressed }\end{array}$ & -0.75596 & -0.17138 & 0.980372 & -0.156 & -0.42013 & -0.3124 & Figure 4 \\
\hline LOC_Os08g 13440 & $\begin{array}{l}\text { cupin domain containing protein, } \\
\text { expressed }\end{array}$ & -0.80972 & -0.40119 & 1.789424 & 0.602279 & -1.80766 & -0.91025 & Figure 4 \\
\hline LOC_Os08g14440 & $\begin{array}{l}\text { uridylyltransferase-related, putative, } \\
\text { expressed }\end{array}$ & -0.83642 & -0.39685 & 0.751591 & -0.20914 & -1.28334 & -0.3443 & Figure 4 \\
\hline LOC_Os08g26230 & expressed protein & -1.18214 & 1.42847 & -0.72554 & 1.081431 & -1.33206 & & Figure 4 \\
\hline
\end{tabular}




\begin{tabular}{|c|c|c|c|c|c|c|c|c|}
\hline LOC_Os08g26820 & $\begin{array}{l}\text { plant protein of unknown function } \\
\text { domain containing protein, } \\
\text { expressed }\end{array}$ & -0.82197 & 0.613377 & -0.63966 & 1.823608 & -0.42415 & 0.42165 & Figure 4 \\
\hline LOC_Os08g26840 & $\begin{array}{l}\text { plant protein of unknown function } \\
\text { domain containing protein, } \\
\text { expressed }\end{array}$ & -0.93502 & 0.608336 & -0.78005 & 2.432813 & 0.313988 & -0.28645 & Figure 4 \\
\hline LOC_Os08g27840 & $\begin{array}{l}\text { phosphoenolpyruvate carboxylase, } \\
\text { putative, expressed }\end{array}$ & -0.8157 & 0.561896 & 1.932299 & -0.05879 & -0.32888 & -0.0799 & Figure 4 \\
\hline LOC_Os08g31410 & $\begin{array}{l}\text { sulfate transporter, putative, } \\
\text { expressed }\end{array}$ & -0.51642 & 0.86571 & 0.689295 & -0.31539 & -0.1727 & 1.3203 & Figure 4 \\
\hline LOC_Os08g31470 & $\begin{array}{l}\text { peptidase, trypsin-like serine and } \\
\text { cysteine proteases, putative, } \\
\text { expressed }\end{array}$ & -0.83115 & 0.639277 & 0.770847 & -0.07416 & -0.3675 & -0.03595 & Figure 4 \\
\hline LOC_Os08g34280 & $\begin{array}{l}\text { cinnamoyl-CoA reductase, putative, } \\
\text { expressed }\end{array}$ & -0.21915 & 1.332616 & 0.84905 & -0.49974 & -0.5305 & 2.0953 & Figure 4 \\
\hline LOC_Os08g42370 & $\begin{array}{l}\text { zinc finger DHHC } \\
\text { domain-containing protein, putative, } \\
\text { expressed }\end{array}$ & -0.79692 & 0.255648 & 1.192034 & 1.584436 & -0.09238 & 0.7129 & Figure 4 \\
\hline LOC_Os08g44210 & $\begin{array}{l}\text { dihydroneopterin aldolase, putative, } \\
\text { expressed }\end{array}$ & -0.07519 & 1.221587 & 0.767862 & 1.269775 & -0.01206 & & Figure 4 \\
\hline LOC_Os09g02214 & $\begin{array}{l}\text { Citrate transporter protein, putative, } \\
\text { expressed }\end{array}$ & -0.72081 & 0.074592 & 0.955266 & 0.020841 & -1.11475 & -0.10675 & Figure 4 \\
\hline LOC_Os09g08390 & $\begin{array}{l}\text { CRAL/TRIO domain containing } \\
\text { protein, expressed }\end{array}$ & -0.30332 & 1.275875 & 0.620181 & -0.365 & 1.445625 & 0.4374 & Figure 4 \\
\hline LOC_Os09g13440 & expressed protein & -1.74367 & 1.864749 & -0.16591 & 0.176548 & -0.24498 & & Figure 4 \\
\hline LOC_Os09g13460 & expressed protein & -1.01061 & 1.669729 & -0.24399 & & & & Figure 4 \\
\hline LOC_Os09g14440 & hypothetical protein & -0.8808 & 1.352768 & -0.21286 & & & & Figure 4 \\
\hline LOC_Os09g20350 & $\begin{array}{l}\text { ethylene-responsive transcription } \\
\text { factor, putative, expressed }\end{array}$ & -0.68531 & -0.1428 & 1.089021 & 0.056874 & 0.047125 & 0.0824 & Figure 4 \\
\hline LOC_Os09g25060 & WRKY76, expressed & -0.98184 & 1.784391 & 0.679818 & 4.088948 & 0.356925 & -0.35855 & Figure 4 \\
\hline LOC_Os09g25070 & WRKY62, expressed & -1.17178 & 1.135785 & 1.356364 & 5.448968 & 0.26715 & 1.1186 & Figure 4 \\
\hline LOC_Os09g27560 & expressed protein & -0.54122 & 1.61296 & 0.632241 & & & & Figure 4 \\
\hline LOC_Os09g27580 & $\begin{array}{l}\text { potassium transporter, putative, } \\
\text { expressed }\end{array}$ & -1.14163 & 1.968905 & 0.777529 & 1.850103 & -0.6581 & -0.61455 & Figure 4 \\
\hline LOC_Os09g29200 & $\begin{array}{l}\text { glutathione S-transferase, putative, } \\
\text { expressed }\end{array}$ & -1.05684 & 0.880411 & 0.982377 & 1.165847 & -0.06325 & -0.1917 & Figure 4 \\
\hline LOC_Os09g34280 & $\begin{array}{l}\text { ankyrin repeat-containing protein, } \\
\text { putative, expressed }\end{array}$ & -0.6773 & -0.25578 & 1.177433 & -0.20306 & 0.236125 & -0.03985 & Figure 4 \\
\hline LOC_Os09g36200 & $\begin{array}{l}\text { senescence-inducible chloroplast } \\
\text { stay-green protein 1, putative, } \\
\text { expressed }\end{array}$ & -0.03029 & 1.245938 & 1.120025 & 0.406153 & 3.31125 & 1.3453 & Figure 4 \\
\hline LOC_Os09g36300 & $\begin{array}{l}\text { OsLonP4 - Putative Lon protease } \\
\text { homologue, expressed }\end{array}$ & -0.93291 & -0.20606 & 0.822577 & 0.417583 & 0.057125 & 0.5832 & Figure 4 \\
\hline LOC_Os09g37012 & $\begin{array}{l}\text { eukaryotic aspartyl protease domain } \\
\text { containing protein, expressed }\end{array}$ & -0.64697 & -0.36589 & 1.506965 & 0.041825 & -0.08663 & 0.7824 & Figure 4 \\
\hline LOC_Os09g39650 & $\begin{array}{l}\text { protein kinase family protein, } \\
\text { putative, expressed }\end{array}$ & -0.93158 & 1.144367 & 0.854584 & 0.299028 & -0.30216 & -0.47365 & Figure 4 \\
\hline LOC_Os10g05210 & $\begin{array}{l}\text { OsFBX368 - F-box domain } \\
\text { containing protein, expressed }\end{array}$ & -0.90651 & 1.088556 & 0.461708 & -0.09681 & 0.063588 & -0.1622 & Figure 4 \\
\hline LOC_Os10g10130 & $\begin{array}{l}\text { OsWAK112d - OsWAK } \\
\text { receptor-like protein kinase, } \\
\text { expressed }\end{array}$ & -1.23226 & -0.35722 & 1.434578 & 0.464137 & -0.18563 & -0.15035 & Figure 4 \\
\hline LOC_Os10g27230 & $\begin{array}{l}\text { endonuclease/exonuclease/phosphat } \\
\text { ase family domain containing } \\
\text { protein, expressed }\end{array}$ & -0.82868 & -0.27237 & 0.920414 & 0.078359 & -0.10988 & 0.0577 & Figure 4 \\
\hline
\end{tabular}




\begin{tabular}{|c|c|c|c|c|c|c|c|c|}
\hline LOC_Os10g28080 & $\begin{array}{l}\text { glycosyl hydrolase, putative, } \\
\text { expressed }\end{array}$ & -0.11884 & 0.865343 & 0.971423 & 0.288969 & 1.774362 & 2.66235 & Figure 4 \\
\hline LOC_Os10g28200 & $\begin{array}{l}\text { NAD dependent } \\
\text { epimerase/dehydratase family } \\
\text { protein, putative, expressed }\end{array}$ & -0.77035 & -0.84127 & 1.2388 & 0.624559 & -0.53288 & & Figure 4 \\
\hline LOC_Os10g34400 & expressed protein & -0.97528 & -0.11971 & 1.440205 & 0.214561 & -0.91703 & & Figure 4 \\
\hline LOC_Os10g37730 & pollen ankyrin, putative, expressed & -0.74848 & -0.22441 & 0.988011 & 0.004502 & 0.056538 & -0.1448 & Figure 4 \\
\hline LOC_Os10g39140 & $\begin{array}{l}\text { flavonol synthase/flavanone } \\
\text { 3-hydroxylase, putative, expressed }\end{array}$ & -0.77322 & 1.514981 & -0.05439 & 3.239305 & 2.323125 & 0.1602 & Figure 4 \\
\hline LOC_Os10g41980 & $\begin{array}{l}\text { RALFL26 - Rapid ALkalinization } \\
\text { Factor RALF family protein } \\
\text { precursor, expressed }\end{array}$ & 0.45632 & 0.735282 & 1.420188 & 0.722995 & -1.44296 & 0.07175 & Figure 4 \\
\hline LOC_Os10g42240 & $\begin{array}{l}\text { kinase, pfkB family, putative, } \\
\text { expressed }\end{array}$ & -0.93769 & -0.49049 & 0.673269 & -0.19108 & -1.26579 & -0.76145 & Figure 4 \\
\hline LOC_Os11g02150 & $\begin{array}{l}\text { saposin-like type B, region } 1 \text { family } \\
\text { protein, putative, expressed }\end{array}$ & -0.80437 & -0.58257 & 1.362907 & -0.09216 & 0.43175 & & Figure 4 \\
\hline LOC_Os11g02530 & WRKY40, expressed & -0.21467 & 2.100624 & 0.735403 & 2.091132 & 2.9033 & & Figure 4 \\
\hline LOC_Os11g02540 & WRKY50, expressed & -0.69727 & 2.434097 & 0.938227 & & & & Figure 4 \\
\hline LOC_Os11g03230 & $\begin{array}{l}\text { nucleoside-triphosphatase, putative, } \\
\text { expressed }\end{array}$ & -0.94344 & 0.721348 & 0.209449 & 0.578286 & 0.033975 & & Figure 4 \\
\hline LOC_Os11g04030 & $\begin{array}{l}\text { major facilitator superfamily } \\
\text { antiporter, putative, expressed }\end{array}$ & -0.03804 & 2.243273 & 0.699938 & -0.01716 & -0.35671 & -0.2025 & Figure 4 \\
\hline LOC_Os11g05990 & $\begin{array}{l}\text { digalactosyldiacylglycerol synthase, } \\
\text { chloroplast precursor, putative, } \\
\text { expressed }\end{array}$ & -0.13223 & 0.885596 & 0.611005 & -0.1419 & 0.552 & 0.4773 & Figure 4 \\
\hline LOC_Os11g06200 & expressed protein & 0.569491 & 1.515629 & 0.677455 & & & & Figure 4 \\
\hline LOC_Os11g07930 & $\begin{array}{l}\text { oxidoreductase, short chain } \\
\text { dehydrogenase/reductase family } \\
\text { domain containing family, } \\
\text { expressed }\end{array}$ & 0.210138 & 0.741941 & 0.815496 & 0.005564 & -2.79648 & 0.15865 & Figure 4 \\
\hline LOC_Os11g10100 & $\begin{array}{l}\text { STE_MEKK_ste11_MAP3K.3 - } \\
\text { STE kinases include homologs to } \\
\text { sterile } 7, \text { sterile } 11 \text { and sterile } 20 \\
\text { from yeast, expressed }\end{array}$ & -0.80011 & -0.28149 & 0.934303 & 0.767809 & 0.363875 & & Figure 4 \\
\hline LOC_Os11g11960 & $\begin{array}{l}\text { disease resistance protein RPM1, } \\
\text { putative, expressed }\end{array}$ & -1.00802 & 0.902514 & 0.398861 & & & & Figure 4 \\
\hline LOC_Os11g12340 & $\begin{array}{l}\text { disease resistance protein RPM1, } \\
\text { putative, expressed }\end{array}$ & -1.24499 & 0.871429 & -0.1817 & 1.657166 & -0.56688 & 0.6507 & Figure 4 \\
\hline LOC_Os11g21990 & expressed protein & -0.64228 & 0.244341 & 1.398549 & 0.029983 & -0.43575 & -0.06895 & Figure 4 \\
\hline LOC_Os11g24540 & $\begin{array}{l}\text { signal peptide peptidase-like 2B, } \\
\text { putative, expressed }\end{array}$ & -0.6603 & -0.16015 & 0.971524 & -0.13517 & 0.449975 & 0.6029 & Figure 4 \\
\hline LOC_Os11g28270 & $\begin{array}{l}\text { zinc finger } \mathrm{C}-\mathrm{x} 8-\mathrm{C}-\mathrm{x} 5-\mathrm{C}-\mathrm{x} 3-\mathrm{H} \text { type } \\
\text { family protein, expressed }\end{array}$ & -0.60218 & 0.719985 & 1.200292 & 0.089814 & -0.05121 & -1.06215 & Figure 4 \\
\hline LOC_Os11g36430 & $\begin{array}{l}\text { zinc finger, } \mathrm{C} 3 \mathrm{HC} 4 \text { type domain } \\
\text { containing protein, expressed }\end{array}$ & -0.87359 & -0.43173 & 0.982362 & 0.030891 & -0.23775 & 0.0256 & Figure 4 \\
\hline LOC_Os11g37950 & $\begin{array}{l}\text { WIP3 - Wound-induced protein } \\
\text { precursor, expressed }\end{array}$ & -0.40058 & 0.890427 & 1.717969 & 0.567761 & 3.542775 & & Figure 4 \\
\hline LOC_Os11g37960 & $\begin{array}{l}\text { WIP4 - Wound-induced protein } \\
\text { precursor, expressed }\end{array}$ & 0.285787 & 0.689607 & 0.867366 & 0.143319 & 0.367288 & 1.5385 & Figure 4 \\
\hline LOC_Os11g39370 & $\begin{array}{l}\text { BRASSINOSTEROID } \\
\text { INSENSITIVE } 1 \text {-associated } \\
\text { receptor kinase } 1 \text { precursor, } \\
\text { putative, expressed }\end{array}$ & -1.04181 & 1.829413 & 0.780994 & 0.943142 & 0.154625 & -0.1077 & Figure 4 \\
\hline LOC_Os11g46810 & $\begin{array}{l}\text { retrotransposon protein, putative, } \\
\text { unclassified, expressed }\end{array}$ & -1.01768 & 1.377193 & -0.47287 & & & & Figure 4 \\
\hline
\end{tabular}




\begin{tabular}{|c|c|c|c|c|c|c|c|c|}
\hline LOC_Os11g48020 & $\begin{array}{l}\text { fatty acid hydroxylase, putative, } \\
\text { expressed }\end{array}$ & 0.3678 & 0.820391 & 0.98204 & & & -0.6619 & Figure 4 \\
\hline LOC_Os12g02320 & $\begin{array}{l}\text { LTPL12 - Protease inhibitor/seed } \\
\text { storage/LTP family protein } \\
\text { precursor, expressed }\end{array}$ & 0.31304 & 1.101199 & 0.745428 & -0.15737 & -1.55938 & & Figure 4 \\
\hline LOC_Os12g02450 & WRKY64, expressed & -0.09472 & 2.125418 & 0.896351 & 2.50443 & 2.8683 & & Figure 4 \\
\hline LOC_Os12g02470 & WRKY65, expressed & -0.32874 & 2.499243 & 0.980709 & & & & Figure 4 \\
\hline LOC_Os12g05110 & pyruvate kinase, putative, expressed & -0.60497 & 0.254239 & 1.176003 & 0.031856 & 0.95775 & 0.0352 & Figure 4 \\
\hline LOC_Os12g07110 & $\begin{array}{l}\text { acyl-CoA synthetase protein, } \\
\text { putative, expressed }\end{array}$ & -0.86414 & -0.25683 & 0.901445 & -0.16841 & -0.802 & -0.4423 & Figure 4 \\
\hline LOC_Os12g08810 & VTC2, putative, expressed & 0.06484 & 1.363664 & 1.037753 & -0.18673 & 0.72975 & -0.2396 & Figure 4 \\
\hline LOC_Os12g09700 & $\begin{array}{l}\text { Jacalin-like lectin domain } \\
\text { containing protein, putative, } \\
\text { expressed }\end{array}$ & 0.44961 & 1.752022 & 1.401411 & 0.029894 & 0.21245 & -1.1377 & Figure 4 \\
\hline LOC_Os12g09739 & $\begin{array}{l}\text { pollen signalling protein with } \\
\text { adenylyl cyclase activity, putative, } \\
\text { expressed }\end{array}$ & 0.54678 & 0.953602 & 1.11887 & -0.12803 & 0.132138 & 0.2602 & Figure 4 \\
\hline LOC_Os12g10740 & $\begin{array}{l}\text { leucine-rich repeat family protein, } \\
\text { putative, expressed }\end{array}$ & -1.13728 & 0.384152 & 1.260968 & 0.895482 & -0.61535 & 0.50175 & Figure 4 \\
\hline LOC_Os12g12560 & $\begin{array}{l}\text { NADP-dependent oxidoreductase, } \\
\text { putative, expressed }\end{array}$ & 0.373785 & 1.001344 & 0.753859 & -0.23166 & 0.801388 & 0.30095 & Figure 4 \\
\hline LOC_Os12g14440 & $\begin{array}{l}\text { Jacalin-like lectin domain } \\
\text { containing protein, putative, } \\
\text { expressed }\end{array}$ & -0.66272 & 2.85033 & 2.345581 & 8.118299 & 1.882363 & -0.2118 & Figure 4 \\
\hline LOC_Os12g21700 & $\begin{array}{l}\text { zinc finger } \mathrm{C}-\mathrm{x} 8-\mathrm{C}-\mathrm{x} 5-\mathrm{C}-\mathrm{x} 3-\mathrm{H} \text { type } \\
\text { family protein, expressed }\end{array}$ & -0.88214 & -0.24038 & 0.686118 & -0.09197 & -0.03688 & -0.1647 & Figure 4 \\
\hline LOC_Os12g23180 & $\begin{array}{l}\text { 3-beta hydroxysteroid } \\
\text { dehydrogenase/isomerase family } \\
\text { protein, putative, expressed }\end{array}$ & -0.9701 & -0.62121 & 1.117991 & 0.160354 & -2.508 & 0.92695 & Figure 4 \\
\hline LOC_Os12g25170 & $\begin{array}{l}\text { NB-ARC domain containing disease } \\
\text { resistance protein, putative, } \\
\text { expressed }\end{array}$ & -0.81503 & 0.799392 & 1.147597 & 0.200379 & -0.75253 & 0.15205 & Figure 4 \\
\hline LOC_Os12g31440 & expressed protein & -0.73009 & -0.0734 & 0.926051 & -0.05146 & -0.1895 & & Figure 4 \\
\hline LOC_Os12g35470 & expressed protein & 0.068304 & 2.197839 & 1.859015 & & & & Figure 4 \\
\hline LOC_Os12g36830 & $\begin{array}{l}\text { pathogenesis-related Bet v I family } \\
\text { protein, putative, expressed }\end{array}$ & -0.33356 & 1.624627 & 1.670813 & 1.647349 & 1.482 & 1.73845 & Figure 4 \\
\hline LOC_Os12g36860 & $\begin{array}{l}\text { pathogenesis-related protein } 10, \\
\text { putative, expressed }\end{array}$ & -0.2086 & 1.407116 & 0.6022 & 1.948627 & 2.18025 & & Figure 4 \\
\hline LOC_Os12g36880 & $\begin{array}{l}\text { pathogenesis-related Bet v I family } \\
\text { protein, putative, expressed }\end{array}$ & -0.63953 & 1.996695 & 1.565929 & 2.077135 & 4.228 & 1.00465 & Figure 4 \\
\hline LOC_Os12g37260 & $\begin{array}{l}\text { lipoxygenase } 2.1 \text {, chloroplast } \\
\text { precursor, putative, expressed }\end{array}$ & -0.56542 & 2.814567 & 2.426765 & 3.154193 & 1.94555 & 0.86435 & Figure 4 \\
\hline LOC_Os12g37350 & $\begin{array}{l}\text { lipozygenase protein, putative, } \\
\text { expressed }\end{array}$ & -0.16203 & 1.039084 & 0.770961 & 2.681751 & 1.506125 & & Figure 4 \\
\hline LOC_Os12g42850 & $\begin{array}{l}\text { amino acid permease, putative, } \\
\text { expressed }\end{array}$ & -1.19914 & -0.09983 & 1.289242 & 0.196122 & 0.631125 & 1.117 & Figure 4 \\
\hline LOC_Os12g43380 & thaumatin, putative, expressed & -0.41786 & 2.357376 & 0.709838 & 1.25965 & 3.374325 & & Figure 4 \\
\hline LOC_Os08g14570 & $\begin{array}{l}\text { NADPH reductase, putative, } \\
\text { expressed }\end{array}$ & 0.517677 & 1.025565 & 0.598779 & -0.13045 & 0.750875 & 1.7309 & \\
\hline LOC_Os09g29404 & $\begin{array}{l}\text { glycogen operon protein glgX, } \\
\text { putative, expressed }\end{array}$ & -0.18005 & 0.880238 & 0.588289 & 0.258458 & -1.52638 & -0.51135 & \\
\hline LOC_Os12g05700 & $\begin{array}{l}\text { transposon protein, putative, } \\
\text { Mutator sub-class, expressed }\end{array}$ & 0.369847 & 0.817296 & 0.584349 & & & & \\
\hline LOC_Os10g04520 & expressed protein & 0.134036 & 1.35022 & 0.576641 & 0.104868 & 0.954575 & & \\
\hline LOC_Os01g63389 & hypothetical protein & 0.803083 & 1.430825 & 0.576128 & & & & \\
\hline LOC_Os01g14640 & expressed protein & 0.370379 & 1.015062 & 0.574099 & 0.068946 & -0.03423 & -0.16475 & \\
\hline
\end{tabular}




\begin{tabular}{|c|c|c|c|c|c|c|c|}
\hline LOC_Os02g13380 & $\begin{array}{l}\text { early nodulin } 93 \text { ENOD } 93 \text { protein, } \\
\text { putative, expressed }\end{array}$ & -0.09457 & 0.822812 & 0.566767 & 1.065371 & 1.572625 & 0.00655 \\
\hline LOC_Os01g42620 & $\begin{array}{l}\text { pentatricopeptide containing } \\
\text { protein, putative, expressed }\end{array}$ & 0.087389 & 0.811243 & 0.556116 & 0.019363 & -0.05698 & -0.87465 \\
\hline LOC_Os04g06520 & expressed protein & -0.25421 & 1.425418 & 0.540897 & 1.964411 & -0.12266 & 0.39305 \\
\hline LOC_Os04g04480 & $\begin{array}{l}\text { retrotransposon protein, putative, } \\
\text { unclassified, expressed }\end{array}$ & 0.536282 & 0.801622 & 0.533211 & & & \\
\hline LOC_Os02g09490 & dehydrogenase, putative, expressed & 0.444607 & 1.312049 & 0.532822 & -0.28538 & 1.340375 & 0.6383 \\
\hline LOC_Os01g42380 & $\begin{array}{l}\text { pleiotropic drug resistance protein, } \\
\text { putative, expressed }\end{array}$ & -0.12757 & 1.108099 & 0.526731 & 1.305995 & 3.3281 & 1.5953 \\
\hline LOC_Os07g44130 & $\begin{array}{l}\text { cytochrome P450 72A1, putative, } \\
\text { expressed }\end{array}$ & 0.021826 & 0.941717 & 0.521432 & 0.831575 & 0.588 & \\
\hline LOC_Os02g45320 & $\begin{array}{l}\text { OsFBX58 - F-box domain } \\
\text { containing protein, expressed }\end{array}$ & 0.219663 & 1.210373 & 0.520475 & 0.351903 & -0.01745 & 0.8323 \\
\hline LOC_Os12g36850 & $\begin{array}{l}\text { pathogenesis-related Bet v I family } \\
\text { protein, putative, expressed }\end{array}$ & -0.38411 & 1.894099 & 0.516728 & 0.802171 & 1.8705 & 3.1032 \\
\hline LOC_Os10g39680 & $\begin{array}{l}\text { CHIT14 - Chitinase family protein } \\
\text { precursor, expressed }\end{array}$ & -0.24249 & 1.550733 & 0.50076 & 2.145026 & 2.604875 & 1.31645 \\
\hline LOC_Os04g27100 & hypothetical protein & -0.02872 & 1.049868 & 0.495879 & & & 2.2737 \\
\hline LOC_Os03g44050 & $\begin{array}{l}\text { OsWAK27 - OsWAK receptor-like } \\
\text { protein kinase, expressed }\end{array}$ & 0.209963 & 0.973302 & 0.49585 & & & \\
\hline LOC_Os01g72120 & $\begin{array}{l}\text { glutathione S-transferase, putative, } \\
\text { expressed }\end{array}$ & -0.3265 & 1.019674 & 0.464075 & 1.867619 & 1.865525 & 0.2161 \\
\hline LOC_Os06g32674 & hypothetical protein & 0.55184 & 2.269339 & 0.460869 & & & \\
\hline LOC_Os03g03790 & $\begin{array}{l}\text { AMP-binding domain containing } \\
\text { protein, expressed }\end{array}$ & 0.267325 & 1.33569 & 0.452941 & 0.708217 & 0.493938 & 1.0399 \\
\hline LOC_Os07g34990 & $\begin{array}{l}\text { retrotransposon protein, putative, } \\
\text { unclassified, expressed }\end{array}$ & 1.400493 & 1.117683 & 0.442836 & & & \\
\hline LOC_Os10g42130 & $\begin{array}{l}\text { no apical meristem protein, putative, } \\
\text { expressed }\end{array}$ & 0.124453 & 1.258757 & 0.427524 & 0.899073 & -1.39631 & 0.14055 \\
\hline LOC_Os08g30510 & expressed protein & -0.03211 & 0.888445 & 0.402044 & 0.078832 & 0.5771 & 0.3708 \\
\hline LOC_Os01g38359 & $\begin{array}{l}\text { peptidyl-prolyl cis-trans isomerase, } \\
\text { FKBP-type, putative, expressed }\end{array}$ & -0.30902 & 0.851084 & 0.396711 & 0.002798 & -0.67865 & 0.07365 \\
\hline LOC_Os06g47200 & $\begin{array}{l}\text { LTPL85 - Protease inhibitor/seed } \\
\text { storage/LTP family protein } \\
\text { precursor, expressed }\end{array}$ & 0.216743 & 0.875242 & 0.39229 & -0.0621 & 0.386563 & 0.5289 \\
\hline LOC_Os08g04230 & $\begin{array}{l}\text { cysteine-rich repeat secretory } \\
\text { protein } 55 \text { precursor, putative, } \\
\text { expressed }\end{array}$ & 1.049796 & 2.14292 & 0.384696 & -0.06817 & -0.17916 & 0.8203 \\
\hline LOC_Os11g29870 & WRKY72, expressed & 0.269616 & 1.12951 & 0.380616 & 1.15141 & 2.8793 & 3.64035 \\
\hline LOC_Os09g27520 & expressed protein & 0.940414 & 0.968126 & 0.373085 & & & \\
\hline LOC_Os01g37390 & $\begin{array}{l}\text { retrotransposon protein, putative, } \\
\text { unclassified, expressed }\end{array}$ & -0.11465 & 0.903981 & 0.356786 & & & \\
\hline LOC_Os01g32460 & expressed protein & -0.20262 & 0.913044 & 0.338687 & 4.661748 & -0.27636 & \\
\hline LOC_Os01g09190 & expressed protein & -0.57563 & 0.926198 & 0.327973 & 0.389842 & -0.18744 & 0.33465 \\
\hline LOC_Os11g07850 & $\begin{array}{l}\text { Protein-tyrosine phosphatase } \\
\text { domain containing protein, } \\
\text { expressed }\end{array}$ & -0.4085 & 0.812833 & 0.3279 & 0.617676 & 0.73575 & \\
\hline LOC_Os08g25310 & $\begin{array}{l}\text { phosphatidylinositol transfer, } \\
\text { putative, expressed }\end{array}$ & 0.275665 & 0.82753 & 0.323732 & -0.01711 & 0.219163 & 0.1328 \\
\hline LOC_Os12g12090 & expressed protein & -0.17847 & 1.458025 & 0.319071 & 0.070244 & -0.15821 & 0.56635 \\
\hline LOC_Os12g42980 & $\begin{array}{l}\text { cysteine synthase, putative, } \\
\text { expressed }\end{array}$ & -0.28446 & 0.967386 & 0.311369 & 0.041093 & -0.01888 & -0.2465 \\
\hline LOC_Os06g47230 & $\begin{array}{l}\text { coiled-coil domain-containing } \\
\text { protein } 72 \text {, putative, expressed }\end{array}$ & 0.245309 & 0.903906 & 0.298568 & 0.096099 & 0.745125 & 0.283 \\
\hline
\end{tabular}




\begin{tabular}{|c|c|c|c|c|c|c|c|}
\hline LOC_Os09g38020 & $\begin{array}{l}\text { Core histone } \mathrm{H} 2 \mathrm{~A} / \mathrm{H} 2 \mathrm{~B} / \mathrm{H} 3 / \mathrm{H} 4 \\
\text { domain containing protein, putative, } \\
\text { expressed }\end{array}$ & 0.789403 & 0.92825 & 0.294242 & 0.388692 & -0.117 & \\
\hline LOC_Os03g38790 & expressed protein & 0.745584 & 1.503607 & 0.292124 & 0.190029 & 0.5032 & 0.17365 \\
\hline LOC_Os07g29960 & $\begin{array}{l}\text { cytochrome P450, putative, } \\
\text { expressed }\end{array}$ & 0.038416 & 0.979755 & 0.289449 & -0.12992 & 0.567375 & \\
\hline LOC_Os01g66020 & $\begin{array}{l}\text { protein kinase family protein, } \\
\text { putative, expressed }\end{array}$ & 0.569928 & 1.435638 & 0.284799 & 0.479999 & -2.35851 & \\
\hline LOC_Os09g36860 & $\begin{array}{l}\text { acyl carrier protein, putative, } \\
\text { expressed }\end{array}$ & 0.212074 & 1.144683 & 0.272877 & -0.19698 & 0.827763 & -0.14125 \\
\hline LOC_Os11g08100 & $\begin{array}{l}\text { eukaryotic aspartyl protease domain } \\
\text { containing protein, expressed }\end{array}$ & 0.250838 & 0.805867 & 0.271172 & 0.6558 & 1.96725 & 0.4285 \\
\hline LOC_Os03g29810 & $\begin{array}{l}\text { OsClp6 - Putative Clp protease } \\
\text { homologue, expressed }\end{array}$ & 0.380819 & 0.819027 & 0.267026 & -0.04466 & -0.77219 & -0.77945 \\
\hline LOC_Os02g47650 & $\begin{array}{l}\text { universal stress protein domain } \\
\text { containing protein, putative, } \\
\text { expressed }\end{array}$ & -0.4703 & 1.218947 & 0.263932 & 1.122829 & 2.389425 & 2.2264 \\
\hline LOC_Os08g26350 & expressed protein & 0.208753 & 0.932967 & 0.261943 & 0.122034 & 0.277838 & \\
\hline LOC_Os08g 13270 & expressed protein & 0.032641 & 0.803642 & 0.255814 & & & 0.10205 \\
\hline LOC_Os01g66260 & expressed protein & 0.489091 & 1.205067 & 0.254066 & & & \\
\hline LOC_Os07g48310 & $\begin{array}{l}\text { inactive receptor kinase At2g26730 } \\
\text { precursor, putative, expressed }\end{array}$ & -0.00677 & 0.8385 & 0.250737 & 1.015334 & 0.12645 & -0.1533 \\
\hline LOC_Os07g34720 & $\begin{array}{l}\text { harpin-induced protein } 1 \text { domain } \\
\text { containing protein, expressed }\end{array}$ & 0.942009 & 0.927974 & 0.227188 & -0.22752 & -0.10996 & \\
\hline LOC_Os03g21470 & hypothetical protein & 0.539293 & 1.272535 & 0.222811 & -0.06473 & 0.035738 & \\
\hline LOC_Os03g16910 & SLT1 protein, putative, expressed & 0.261247 & 0.80941 & 0.212241 & 0.027945 & -0.01338 & 0.0756 \\
\hline LOC_Os01g10450 & $\begin{array}{l}\text { protein kinase domain containing } \\
\text { protein, expressed }\end{array}$ & 0.062891 & 1.161433 & 0.210487 & -0.64203 & -1.43829 & 0.37985 \\
\hline LOC_Os01g70380 & $\begin{array}{l}\text { serine palmitoyltransferase } 2 \text {, } \\
\text { putative, expressed }\end{array}$ & 0.058332 & 0.850594 & 0.205318 & 0.116246 & -0.1325 & \\
\hline LOC_Os04g10000 & $\begin{array}{l}\text { sex determination protein } \\
\text { tasselseed-2, putative, expressed }\end{array}$ & -0.25757 & 0.81185 & 0.199029 & 0.389432 & 1.531363 & \\
\hline LOC_Os10g42710 & RCD1, putative, expressed & 0.04682 & 0.856264 & 0.197557 & 0.051698 & 0.14 & 0.5074 \\
\hline LOC_Os04g35520 & $\begin{array}{l}\text { OsAPx7 - Stromal Ascorbate } \\
\text { Peroxidase encoding gene 5,8, } \\
\text { expressed }\end{array}$ & -0.56916 & 0.965237 & 0.194587 & 0.181532 & 0.113625 & 0.38605 \\
\hline LOC_Os07g48060 & $\begin{array}{l}\text { peroxidase precursor, putative, } \\
\text { expressed }\end{array}$ & -0.32617 & 1.278839 & 0.193109 & 0.355389 & -0.04315 & 0.20455 \\
\hline LOC_Os06g37070 & expressed protein & -0.03137 & 1.005162 & 0.191886 & 0.270714 & 0.108875 & \\
\hline LOC_Os10g41838 & $\begin{array}{l}\text { F-box protein interaction domain } \\
\text { containing protein, expressed }\end{array}$ & 0.932503 & 0.894083 & 0.188818 & 0.005115 & -0.29828 & 0.03475 \\
\hline LOC_Os06g40240 & $\begin{array}{l}\text { retrotransposon protein, putative, } \\
\text { unclassified, expressed }\end{array}$ & 1.919841 & 1.371946 & 0.180104 & & & \\
\hline LOC_Os01g48620 & expressed protein & -0.47494 & 0.991977 & 0.178454 & 0.738433 & -0.70741 & \\
\hline LOC_Os10g37160 & $\begin{array}{l}\text { transposon protein, putative, } \\
\text { unclassified, expressed }\end{array}$ & 0.065569 & 2.424127 & 0.175901 & -0.04364 & 0.665913 & 1.3797 \\
\hline LOC_Os05g38520 & $\begin{array}{l}60 \text { S ribosomal protein L36-2, } \\
\text { putative, expressed }\end{array}$ & 0.392614 & 0.830741 & 0.165846 & 0.235314 & -0.26075 & 0.15055 \\
\hline LOC_Os10g41190 & $\begin{array}{l}\text { transporter family protein, putative, } \\
\text { expressed }\end{array}$ & -0.13673 & 1.622247 & 0.15234 & -0.14834 & -1.98736 & -0.33545 \\
\hline LOC_Os03g10100 & $\begin{array}{l}\text { transporter family protein, putative, } \\
\text { expressed }\end{array}$ & -0.00542 & 1.53672 & 0.149307 & 0.174185 & -0.20126 & -1.46955 \\
\hline LOC_Os10g39710 & $\begin{array}{l}\text { strictosidine synthase, putative, } \\
\text { expressed }\end{array}$ & -0.33354 & 1.567622 & 0.145574 & 0.645725 & -0.30749 & 0.1142 \\
\hline LOC_Os12g01530 & $\begin{array}{l}\text { ferritin-1, chloroplast precursor, } \\
\text { putative, expressed }\end{array}$ & 0.578497 & 1.208198 & 0.127761 & 0.348227 & 1.8265 & 0.34695 \\
\hline
\end{tabular}




\begin{tabular}{|c|c|c|c|c|c|c|c|}
\hline LOC_Os11g34920 & $\begin{array}{l}\text { stripe rust resistance protein } \text { Yr10, } \\
\text { putative, expressed }\end{array}$ & -0.05823 & 0.80677 & 0.124434 & 0.136032 & -0.07119 & 0.13935 \\
\hline LOC_Os05g 33580 & expressed protein & 0.144575 & 0.84638 & 0.11739 & 0.2226 & -0.33205 & -0.40475 \\
\hline LOC_Os03g59080 & $\begin{array}{l}\text { AMP-binding enzyme, putative, } \\
\text { expressed }\end{array}$ & 0.424125 & 0.85549 & 0.094652 & -0.08367 & 0.423875 & -0.00865 \\
\hline LOC_Os06g13390 & $\begin{array}{l}\text { SAM dependent carboxyl } \\
\text { methyltransferase, putative, } \\
\text { expressed }\end{array}$ & 1.107522 & 1.887983 & 0.090444 & 0.089597 & 5.212725 & \\
\hline LOC_Os03g47280 & $\begin{array}{l}\text { VQ domain containing protein, } \\
\text { putative, expressed }\end{array}$ & -0.29434 & 2.331807 & 0.090302 & 0.692421 & 2.440263 & 2.38675 \\
\hline LOC_Os12g13800 & $\begin{array}{l}\text { O-methyltransferase, putative, } \\
\text { expressed }\end{array}$ & -0.17371 & 2.004835 & 0.090211 & -0.05522 & 1.682625 & \\
\hline LOC_Os03g46070 & thaumatin, putative, expressed & -0.28265 & 1.209647 & 0.077706 & 1.451168 & 5.047762 & \\
\hline LOC_Os03g62420 & expressed protein & 0.32336 & 0.856091 & 0.07758 & -0.05128 & 0.48475 & \\
\hline LOC_Os08g07090 & expressed protein & -0.05133 & 0.990826 & 0.070316 & & & \\
\hline LOC_Os06g40030 & $\begin{array}{l}\text { S-locus-like receptor protein kinase, } \\
\text { putative, expressed }\end{array}$ & -0.05951 & 0.859538 & 0.070013 & 0.979238 & -0.40216 & 1.3066 \\
\hline LOC_Os07g01960 & hypothetical protein & 1.318828 & 0.940819 & 0.060704 & & & \\
\hline LOC_Os01g58280 & $\begin{array}{l}\text { OsSub8 - Putative Subtilisin } \\
\text { homologue, expressed }\end{array}$ & 0.50634 & 0.912495 & 0.040221 & 2.000822 & 0.386 & 1.8865 \\
\hline LOC_Os03g04060 & $\begin{array}{l}\text { CHIT16 - Chitinase family protein } \\
\text { precursor, expressed }\end{array}$ & -0.29093 & 1.012936 & 0.033708 & 1.032299 & -0.30876 & 0.26405 \\
\hline LOC_Os09g28000 & $\begin{array}{l}\text { OsSigP6 - Putative Type I Signal } \\
\text { Peptidase homologue; employs a } \\
\text { putative Ser/Lys catalytic dyad, } \\
\text { expressed }\end{array}$ & -0.20288 & 0.848405 & 0.008806 & 0.708869 & 0.697875 & \\
\hline LOC_Os08g07470 & hypothetical protein & 1.099379 & 1.70653 & 0.002787 & & & \\
\hline LOC_Os04g57730 & $\begin{array}{l}\text { uracil-DNA glycosylase, putative, } \\
\text { expressed }\end{array}$ & 0.404662 & 0.856585 & -0.0176 & 0.031908 & -0.30463 & \\
\hline LOC_Os02g18080 & $\begin{array}{l}\text { NB-ARC domain containing } \\
\text { protein, expressed }\end{array}$ & -0.36652 & 0.975804 & -0.01866 & 0.026415 & -0.21979 & \\
\hline LOC_Os04g33440 & $\begin{array}{l}\text { DNA-binding protein S1FA, } \\
\text { putative, expressed }\end{array}$ & 0.366075 & 0.971709 & -0.02068 & & & \\
\hline LOC_Os11g44390 & $\begin{array}{l}\text { retrotransposon protein, putative, } \\
\text { Ty1-copia subclass, expressed }\end{array}$ & 0.198537 & 1.514221 & -0.02176 & & & \\
\hline LOC_Os05g50940 & expressed protein & -0.10384 & 0.944208 & -0.0237 & 0.1101 & 0.025013 & \\
\hline LOC_Os06g38970 & expressed protein & -0.35112 & 1.253789 & -0.03963 & 0.028584 & 1.539 & -1.0568 \\
\hline LOC_Os11g07780 & hypothetical protein & 0.051251 & 0.854665 & -0.03969 & & & \\
\hline LOC_Os04g09900 & $\begin{array}{l}\text { ent-kaurene synthase, chloroplast } \\
\text { precursor, putative, expressed }\end{array}$ & -0.00479 & 1.821975 & -0.04137 & 0.237114 & 2.1666 & 0.8574 \\
\hline LOC_Os11g25510 & $\begin{array}{l}\text { protein kinase domain containing } \\
\text { protein, expressed }\end{array}$ & 0.220726 & 0.90918 & -0.04551 & 0.009272 & -0.16424 & 1.62915 \\
\hline LOC_Os07g03200 & $\begin{array}{l}\text { phytosulfokines precursor, putative, } \\
\text { expressed }\end{array}$ & 0.149679 & 1.30029 & -0.05178 & 0.948779 & -0.31156 & 0.58545 \\
\hline LOC_Os04g02050 & $\begin{array}{l}\text { bifunctional 3-phosphoadenosine } \\
\text { 5-phosphosulfate synthetase, } \\
\text { putative, expressed }\end{array}$ & 0.38245 & 0.925056 & -0.0563 & -0.23299 & 0.563375 & 0.3866 \\
\hline LOC_Os11g11970 & expressed protein & -0.35672 & 1.146147 & -0.05637 & & & \\
\hline LOC_Os03g16890 & $\begin{array}{l}\mathrm{N} \text {-acetylglucosaminyltransferase, } \\
\text { putative, expressed }\end{array}$ & 1.57564 & 0.981103 & -0.0605 & -0.0341 & 0.204188 & \\
\hline LOC_Os11g30690 & expressed protein & 0.001253 & 1.369467 & -0.06305 & & & \\
\hline LOC_Os07g45350 & $\begin{array}{l}\text { zinc finger, RING-type, putative, } \\
\text { expressed }\end{array}$ & 0.686882 & 1.160784 & -0.08554 & -0.31341 & -0.52675 & -0.30665 \\
\hline LOC_Os12g36250 & $\begin{array}{l}\text { retrotransposon protein, putative, } \\
\text { Ty1-copia subclass, expressed }\end{array}$ & 0.236499 & 0.962 & -0.08726 & & & \\
\hline
\end{tabular}




\begin{tabular}{|c|c|c|c|c|c|c|c|}
\hline LOC_Os01g22370 & $\begin{array}{l}\text { peroxidase precursor, putative, } \\
\text { expressed }\end{array}$ & 0.014049 & 1.094006 & -0.09211 & 0.693886 & -0.2535 & 1.41475 \\
\hline LOC_Os02g04230 & $\begin{array}{l}\text { CGMC_MAPKCMGC_2.7 - } \\
\text { CGMC includes CDA, MAPK, } \\
\text { GSK3, and CLKC kinases, } \\
\text { expressed }\end{array}$ & 0.029934 & 1.0635 & -0.09271 & 0.584453 & 0.650938 & \\
\hline LOC_Os08g03350 & $\begin{array}{l}\text { amino acid transporter, putative, } \\
\text { expressed }\end{array}$ & 0.049052 & 0.894679 & -0.09731 & 1.399948 & 0.88625 & 1.5317 \\
\hline LOC_Os03g20380 & $\begin{array}{l}\text { CAMK_KIN1/SNF1/Nim1_like.2 - } \\
\text { CAMK includes } \\
\text { calcium/calmodulin depedent } \\
\text { protein kinases, expressed }\end{array}$ & 0.180244 & 1.575217 & -0.09739 & 0.346332 & 0.007988 & 0.38025 \\
\hline LOC_Os12g10560 & $\begin{array}{l}\text { clathrin adaptor complex small } \\
\text { chain domain containing protein, } \\
\text { expressed }\end{array}$ & 0.330111 & 1.064096 & -0.1133 & 0.09276 & 0.684913 & 0.82545 \\
\hline LOC_Os02g13430 & $\begin{array}{l}\text { receptor-like protein kinase } 5 \\
\text { precursor, putative, expressed }\end{array}$ & -0.34523 & 0.81309 & -0.11722 & -0.02805 & 0.0824 & \\
\hline LOC_Os02g37180 & expressed protein & -0.23332 & 0.803831 & -0.13071 & 1.190802 & -0.57273 & 0.31015 \\
\hline LOC_Os12g16720 & $\begin{array}{l}\text { cytochrome P450 71A1, putative, } \\
\text { expressed }\end{array}$ & 0.018278 & 1.467189 & -0.13188 & 2.2582 & 0.828163 & 1.01775 \\
\hline LOC_Os01g09800 & $\begin{array}{l}\text { BTBA1 - Bric-a-Brac,Tramtrack, } \\
\text { Broad Complex BTB domain with } \\
\text { Ankyrin repeat region, expressed }\end{array}$ & 0.602012 & 3.403062 & -0.14062 & 1.013809 & 0.65975 & \\
\hline LOC_Os12g42884 & $\begin{array}{l}\text { 5-methyltetrahydropteroyltriglutama } \\
\text { te--homocysteine methyltransferase, } \\
\text { putative, expressed }\end{array}$ & 0.544896 & 1.379718 & -0.14124 & -0.24333 & 0.5925 & -0.08745 \\
\hline LOC_Os01g18800 & $\begin{array}{l}\text { CAMK_KIN1/SNF1/Nim1_like.9 - } \\
\text { CAMK includes } \\
\text { calcium/calmodulin depedent } \\
\text { protein kinases, expressed }\end{array}$ & 0.610288 & 1.656666 & -0.14637 & 0.056477 & -0.61825 & 0.33735 \\
\hline LOC_Os10g34940 & expressed protein & 1.071994 & 1.38556 & -0.15089 & 0.086128 & -0.06356 & -0.5057 \\
\hline LOC_Os08g33740 & $\begin{array}{l}\text { CSLA11 - cellulose synthase-like } \\
\text { family A, expressed }\end{array}$ & -0.21737 & 1.511318 & -0.15232 & 2.44081 & 0.11905 & \\
\hline LOC_Os06g38110 & expressed protein & 0.518951 & 0.944784 & -0.15453 & 0.250105 & 0.783225 & \\
\hline LOC_Os03g21450 & $\begin{array}{l}\text { bromodomain domain containing } \\
\text { protein, expressed }\end{array}$ & 0.939522 & 1.198147 & -0.17603 & & & \\
\hline LOC_Os03g27960 & $\begin{array}{l}\text { sodium/calcium exchanger protein, } \\
\text { putative, expressed }\end{array}$ & 0.169251 & 0.956355 & -0.17963 & 0.170158 & 0.67655 & 0.2142 \\
\hline LOC_Os09g29930 & $\begin{array}{l}\text { transcription factor BIM2, putative, } \\
\text { expressed }\end{array}$ & 0.494588 & 0.90453 & -0.18447 & 0.022334 & 0.5413 & -0.0012 \\
\hline LOC_Os04g50790 & $\begin{array}{l}\text { RNA recognition motif, putative, } \\
\text { expressed }\end{array}$ & 0.517584 & 1.008444 & -0.20382 & 0.461579 & 1.128363 & \\
\hline LOC_Os10g35770 & $\begin{array}{l}\text { E2F-related protein, putative, } \\
\text { expressed }\end{array}$ & -0.14211 & 1.143848 & -0.20575 & -0.68924 & 1.518038 & 1.11 \\
\hline LOC_Os11g09900 & expressed protein & 0.788367 & 1.062645 & -0.22458 & -0.13193 & 0.002525 & \\
\hline LOC_Os01g64780 & COV1, putative, expressed & 0.1875 & 0.836655 & -0.22588 & 0.054963 & 0.1975 & \\
\hline LOC_Os02g30070 & expressed protein & 0.209474 & 0.890075 & -0.22634 & & & \\
\hline LOC_Os10g40740 & $\begin{array}{l}\text { helix-loop-helix DNA-binding } \\
\text { domain containing protein, } \\
\text { expressed }\end{array}$ & 0.992924 & 1.12691 & -0.22791 & -0.36307 & -1.77799 & \\
\hline LOC_Os08g10460 & $\begin{array}{l}\text { retrotransposon protein, putative, } \\
\text { unclassified, expressed }\end{array}$ & 0.829885 & 1.241416 & -0.22964 & & & \\
\hline LOC_Os06g12120 & $\begin{array}{l}\text { BRASSINOSTEROID } \\
\text { INSENSITIVE 1-associated } \\
\text { receptor kinase } 1 \text { precursor, } \\
\text { putative, expressed }\end{array}$ & -0.17064 & 0.982091 & -0.24368 & 0.586526 & -0.53803 & 0.5637 \\
\hline
\end{tabular}




\begin{tabular}{|c|c|c|c|c|c|c|c|}
\hline LOC_Os11g48030 & $\begin{array}{l}\text { skp1 family, tetramerisation domain } \\
\text { containing protein, expressed }\end{array}$ & 1.03037 & 0.866145 & -0.25868 & & & -0.25205 \\
\hline LOC_Os05g21180 & $\begin{array}{l}\text { phosphatidic acid } \\
\text { phosphatase-related, putative, } \\
\text { expressed }\end{array}$ & -0.04158 & 1.193427 & -0.27326 & 0.639835 & 0.909925 & 1.50625 \\
\hline LOC_Os05g10930 & $\begin{array}{l}\text { OsGrx_C15 - glutaredoxin } \\
\text { subgroup III, expressed }\end{array}$ & -0.27119 & 0.861877 & -0.27403 & 0.033054 & -0.76391 & \\
\hline LOC_Os09g31180 & $\begin{array}{l}\text { ribosomal protein } \mathrm{L} 6 \text {, putative, } \\
\text { expressed }\end{array}$ & 0.653113 & 1.003725 & -0.27667 & 0.281798 & -0.25125 & \\
\hline LOC_Os08g05480 & $\begin{array}{l}\text { OsFBX261 - F-box domain } \\
\text { containing protein, expressed }\end{array}$ & -0.4005 & 0.834846 & -0.28147 & 0.778569 & -1.19444 & 2.6675 \\
\hline LOC_Os12g11410 & $\begin{array}{l}\text { retrotransposon protein, putative, } \\
\text { LINE subclass, expressed }\end{array}$ & 0.181072 & 0.981873 & -0.29539 & & & \\
\hline LOC_Os11g12320 & $\begin{array}{l}\text { disease resistance protein RPM1, } \\
\text { putative, expressed }\end{array}$ & 0.814494 & 0.845938 & -0.29987 & & & \\
\hline LOC_Os06g47790 & hypothetical protein & -0.26 & 1.097089 & -0.3111 & & & \\
\hline LOC_Os11g41640 & $\begin{array}{l}\text { helix-loop-helix DNA-binding } \\
\text { domain containing protein, } \\
\text { expressed }\end{array}$ & 0.422971 & 0.820754 & -0.31563 & & & \\
\hline LOC_Os09g39540 & $\begin{array}{l}40 \mathrm{~S} \text { ribosomal protein } \mathrm{S} 25 \text {, putative, } \\
\text { expressed }\end{array}$ & 0.393994 & 0.907492 & -0.35488 & 0.126288 & -0.126 & -0.0918 \\
\hline LOC_Os $05 \mathrm{~g} 46430$ & $\begin{array}{l}60 \text { S ribosomal protein } \mathrm{L} 28-1 \text {, } \\
\text { putative, expressed }\end{array}$ & 0.86141 & 0.993909 & -0.36429 & 0.194403 & -0.09875 & -0.31085 \\
\hline LOC_Os08g42760 & $\begin{array}{l}\text { methyltransferase domain } \\
\text { containing protein, expressed }\end{array}$ & 0.459036 & 0.870726 & -0.36606 & -0.0855 & -0.34428 & -0.63445 \\
\hline LOC_Os11g23080 & $\begin{array}{l}\text { retrotransposon protein, putative, } \\
\text { unclassified, expressed }\end{array}$ & 0.262367 & 1.010006 & -0.36828 & & & 0.3105 \\
\hline LOC_Os04g54200 & $\begin{array}{l}\text { diacylglycerol kinase, putative, } \\
\text { expressed }\end{array}$ & -0.31537 & 0.819092 & -0.38319 & 0.223355 & 2.334363 & 0.34755 \\
\hline LOC_Os05g 11780 & $\begin{array}{l}\text { mitochondrial carrier protein, } \\
\text { putative, expressed }\end{array}$ & 0.317856 & 0.978359 & -0.38368 & -0.00799 & 0.551 & 0.203 \\
\hline LOC_Os01g53770 & expressed protein & 0.793173 & 1.367017 & -0.38774 & 0.007046 & 0.03975 & 0.54465 \\
\hline LOC_Os02g06200 & $\begin{array}{l}\text { phytosulfokine receptor precursor, } \\
\text { putative, expressed }\end{array}$ & -0.23775 & 0.963097 & -0.4035 & & & \\
\hline LOC_Os $12 \mathrm{~g} 02630$ & $\begin{array}{l}\text { cytochrome P450 72A1, putative, } \\
\text { expressed }\end{array}$ & 0.636741 & 0.891183 & -0.41761 & -0.02864 & 0.576725 & 0.5624 \\
\hline LOC_Os07g48430 & $\begin{array}{l}\text { nucleoside-triphosphatase, putative, } \\
\text { expressed }\end{array}$ & 0.011404 & 0.825611 & -0.41889 & 0.258704 & 0.985125 & 0.5101 \\
\hline LOC_Os01g01660 & $\begin{array}{l}\text { isoflavone reductase, putative, } \\
\text { expressed }\end{array}$ & 0.357105 & 0.907572 & -0.42496 & & & 0.43165 \\
\hline LOC_Os08g31630 & $\begin{array}{l}\text { uncharacterized glycosyl hydrolase } \\
\text { Rv2006/MT2062, putative, } \\
\text { expressed }\end{array}$ & 0.349091 & 0.948004 & -0.43089 & -0.36445 & -1.3734 & \\
\hline LOC_Os11g27470 & expressed protein & 0.336224 & 0.810269 & -0.43192 & & & \\
\hline LOC_Os03g09840 & $\begin{array}{l}\mathrm{C} 2 \text { domain containing protein, } \\
\text { putative, expressed }\end{array}$ & -0.15963 & 1.209152 & -0.43786 & -0.03411 & -0.45338 & \\
\hline LOC_Os08g24770 & protein kinase, putative, expressed & -0.1905 & 0.808784 & -0.43984 & 0.119215 & 0.324788 & \\
\hline LOC_Os03g 18590 & $\begin{array}{l}\text { malonyl CoA-acyl carrier protein } \\
\text { transacylase, mitochondrial } \\
\text { precursor, putative, expressed }\end{array}$ & 0.351416 & 0.964893 & -0.44108 & -0.13675 & -1.08286 & -0.25845 \\
\hline LOC_Os08g44450 & $\begin{array}{l}\text { L1P family of ribosomal proteins } \\
\text { domain containing protein, } \\
\text { expressed }\end{array}$ & 0.568743 & 0.939071 & -0.44478 & 0.045145 & -0.25238 & -0.0618 \\
\hline LOC_Os05g45410 & $\begin{array}{l}\text { HSF-type DNA-binding domain } \\
\text { containing protein, expressed }\end{array}$ & 0.021431 & 1.022224 & -0.4558 & 1.27458 & 1.556725 & 2.2887 \\
\hline
\end{tabular}




\begin{tabular}{|c|c|c|c|c|c|c|c|}
\hline LOC_Os08g42910 & $\begin{array}{l}\text { peptidase, M24 family protein, } \\
\text { putative, expressed }\end{array}$ & -0.13001 & 1.194551 & -0.45691 & 0.116872 & 0.559125 & \\
\hline LOC_Os01g45250 & $\begin{array}{l}\text { DUF1645 domain containing } \\
\text { protein, putative, expressed }\end{array}$ & -0.16 & 1.177335 & -0.45929 & 1.190503 & 1.65775 & \\
\hline LOC_Os01g47420 & $\begin{array}{l}\text { pterin-4-alpha-carbinolamine } \\
\text { dehydratase, putative, expressed }\end{array}$ & 0.80168 & 0.853765 & -0.4842 & 0.140474 & -0.22623 & 0.29945 \\
\hline LOC_Os04g16780 & hypothetical protein & 0.458576 & 1.413518 & -0.49487 & & & 0.5908 \\
\hline LOC_Os01g03100 & $\begin{array}{l}\text { protein binding protein, putative, } \\
\text { expressed }\end{array}$ & 0.141046 & 0.809181 & -0.50467 & & & -0.34325 \\
\hline LOC_Os09g04310 & expressed protein & 0.489907 & 0.869788 & -0.51495 & 0.666936 & 1.211788 & 1.8719 \\
\hline LOC_Os08g33920 & $\begin{array}{l}60 \mathrm{~S} \text { ribosomal protein } \mathrm{L} 34 \text {, } \\
\text { putative, expressed }\end{array}$ & 0.697323 & 1.088552 & -0.51768 & 0.174417 & -0.116 & -0.1015 \\
\hline LOC_Os03g63400 & $\begin{array}{l}\text { transcription factor BTF3, putative, } \\
\text { expressed }\end{array}$ & 0.785985 & 1.038759 & -0.52127 & -0.02628 & 0.8548 & -0.4193 \\
\hline LOC_Os08g41300 & $\begin{array}{l}60 \mathrm{~S} \text { ribosomal protein L32, } \\
\text { putative, expressed }\end{array}$ & 0.467819 & 0.815883 & -0.53093 & 0.192694 & -0.03763 & \\
\hline LOC_Os10g20910 & $40 \mathrm{~S}$ ribosomal protein $\mathrm{S} 23$, putative & 0.699975 & 0.887183 & -0.53508 & & & \\
\hline LOC_Os05g46830 & $\begin{array}{l}\text { proline-rich protein, putative, } \\
\text { expressed }\end{array}$ & -0.23184 & 1.341589 & -0.5424 & 0.067859 & 1.564138 & 2.46675 \\
\hline LOC_Os11g40320 & expressed protein & 0.349056 & 0.825271 & -0.54896 & & & \\
\hline LOC_Os08g05530 & $\begin{array}{l}\text { LSM domain containing protein, } \\
\text { expressed }\end{array}$ & 0.537188 & 0.962806 & -0.55309 & 0.104619 & -0.215 & -0.33355 \\
\hline LOC_Os02g32520 & $\begin{array}{l}\text { ERD1 protein, chloroplast } \\
\text { precursor, putative, expressed }\end{array}$ & -0.08501 & 0.881185 & -0.56084 & 1.547589 & 2.486875 & 1.9809 \\
\hline LOC_Os10g35920 & $\begin{array}{l}\text { OsFBX389 - F-box domain } \\
\text { containing protein, expressed }\end{array}$ & -0.13792 & 1.031605 & -0.5682 & 0.583063 & 0.239625 & 0.1726 \\
\hline LOC_Os01g62430 & $\begin{array}{l}\mathrm{C} 2 \text { domain containing protein, } \\
\text { putative, expressed }\end{array}$ & -0.29593 & 0.992829 & -0.5741 & 2.030325 & 2.347925 & \\
\hline LOC_Os11g07280 & $\begin{array}{l}\text { coatomer subunit beta-1, putative, } \\
\text { expressed }\end{array}$ & 0.340602 & 0.966965 & -0.57603 & 0.121668 & 0.801625 & \\
\hline LOC_Os02g48030 & expressed protein & -0.13645 & 0.986382 & -0.58061 & & & \\
\hline LOC_Os06g06760 & protein kinase, putative, expressed & -0.12825 & 0.976154 & -0.59279 & 0.77159 & -0.515 & -0.1646 \\
\hline LOC_Os09g15420 & $\begin{array}{l}\text { NAD dependent } \\
\text { epimerase/dehydratase family } \\
\text { protein, putative, expressed }\end{array}$ & 0.092497 & 1.158289 & -0.59332 & 0.257708 & 2.370713 & 1.83845 \\
\hline LOC_Os04g49757 & $\begin{array}{l}\text { purine permease, putative, } \\
\text { expressed }\end{array}$ & 0.617191 & 1.166246 & -0.61023 & 0.676582 & -1.16581 & 0.388 \\
\hline LOC_Os04g27020 & $\begin{array}{l}\text { cytochrome P450, putative, } \\
\text { expressed }\end{array}$ & 0.047259 & 2.27759 & -0.61485 & 0.629121 & 0.4977 & \\
\hline LOC_Os10g41410 & $\begin{array}{l}\text { nucleoside diphosphate kinase, } \\
\text { putative, expressed }\end{array}$ & 0.207868 & 1.210656 & -0.62351 & 1.389964 & 0.14325 & -0.22565 \\
\hline LOC_Os08g17784 & $\begin{array}{l}\text { purple acid phosphatase, putative, } \\
\text { expressed }\end{array}$ & 0.416011 & 1.011075 & -0.62441 & -0.19014 & -0.09669 & -0.09855 \\
\hline LOC_Os04g22720 & expressed protein & 0.145743 & 0.967069 & -0.63247 & -0.03504 & 0.134525 & 0.107 \\
\hline LOC_Os09g24690 & $\begin{array}{l}\text { 60S ribosomal protein } \mathrm{L} 34 \text {, } \\
\text { putative, expressed }\end{array}$ & 0.821378 & 0.923766 & -0.63807 & 0.092311 & -0.078 & -0.199 \\
\hline LOC_Os07g33910 & $\begin{array}{l}\text { transporter family protein, putative, } \\
\text { expressed }\end{array}$ & 0.975399 & 0.899675 & -0.64215 & -0.70319 & 0.907875 & 0.17375 \\
\hline LOC_Os02g03400 & $\begin{array}{l}\text { microtubule associated protein, } \\
\text { putative, expressed }\end{array}$ & 0.725835 & 1.033361 & -0.64373 & 0.036009 & -0.02354 & 0.50255 \\
\hline LOC_Os05g48220 & $\begin{array}{l}60 \mathrm{~S} \text { ribosomal protein } \mathrm{L} 35 \mathrm{a}-3 \text {, } \\
\text { putative, expressed }\end{array}$ & 0.568089 & 1.104001 & -0.66322 & 0.040336 & 0.192013 & -0.8111 \\
\hline LOC_Os08g24780 & hypothetical protein & 0.939827 & 1.561257 & -0.67731 & & & \\
\hline LOC_Os11g31960 & hypothetical protein & 0.172582 & 0.836706 & -0.68384 & & & \\
\hline LOC_Os11g29014 & $\begin{array}{l}\text { retrotransposon protein, putative, } \\
\text { unclassified, expressed }\end{array}$ & 0.773511 & 0.906192 & -0.69406 & & & \\
\hline
\end{tabular}




\begin{tabular}{|c|c|c|c|c|c|c|c|}
\hline LOC_Os02g03710 & UP-9A, putative, expressed & 0.795204 & 0.907471 & -0.71385 & 1.427998 & 0.011088 & 1.2943 \\
\hline LOC_Os07g45340 & expressed protein & 1.579777 & 1.535197 & -0.71771 & & & \\
\hline LOC_Os11g28910 & $\begin{array}{l}\text { transposon protein, putative, } \\
\text { CACTA, En/Spm sub-class, } \\
\text { expressed }\end{array}$ & 0.756482 & 0.839797 & -0.74493 & 0.08992 & 0.258575 & \\
\hline LOC_Os10g40080 & expressed protein & 0.623923 & 0.830665 & -0.75885 & & & \\
\hline LOC_Os09g11460 & $\begin{array}{l}\text { AP2 domain containing protein, } \\
\text { expressed }\end{array}$ & 0.539806 & 1.274692 & -0.79289 & -0.05673 & 0.73315 & 0.0576 \\
\hline LOC_Os04g39320 & expressed protein & 0.737449 & 1.126122 & -0.8303 & 1.795706 & 1.807063 & 1.44965 \\
\hline LOC_Os05g11710 & $\begin{array}{l}\text { ribosomal protein L5, putative, } \\
\text { expressed }\end{array}$ & 0.658685 & 1.216823 & -0.84018 & 0.190448 & 0.372 & \\
\hline LOC_Os11g44870 & expressed protein & -0.08178 & 0.900852 & -0.8517 & -0.07349 & -0.4875 & 1.313 \\
\hline LOC_Os05g48320 & $\begin{array}{l}60 \mathrm{~S} \text { ribosomal protein } \mathrm{L} 37 \mathrm{a} \text {, } \\
\text { putative, expressed }\end{array}$ & 1.018265 & 0.827976 & -0.89178 & 0.113323 & -0.109 & -0.5055 \\
\hline LOC_Os08g20010 & expressed protein & 0.616284 & 1.134932 & -0.91882 & & & \\
\hline LOC_Os05g08360 & $\begin{array}{l}\text { rRNA 2-O-methyltransferase } \\
\text { fibrillarin 2, putative, expressed }\end{array}$ & 0.814896 & 1.114097 & -0.9797 & 0.376706 & -0.17776 & \\
\hline LOC_Os11g23180 & hypothetical protein & 0.834672 & 1.190009 & -1.00164 & & & \\
\hline LOC_Os08g 17760 & expressed protein & 0.627955 & 0.921569 & -1.03155 & & & \\
\hline LOC_Os11g46950 & $\begin{array}{l}\text { wall-associated receptor kinase-like } \\
18 \text { precursor, putative, expressed }\end{array}$ & -0.11669 & 0.865413 & -1.04704 & -0.12548 & 0.056238 & \\
\hline LOC_Os02g05370 & $\begin{array}{l}\text { retrotransposon protein, putative, } \\
\text { Ty3-gypsy subclass, expressed }\end{array}$ & 0.402893 & 0.85194 & -1.07973 & & & \\
\hline LOC_Os02g11870 & expressed protein & -0.06684 & 1.097439 & -1.08248 & 0.844755 & 2.32635 & 4.13655 \\
\hline LOC_Os10g35450 & $\begin{array}{l}\text { serine/threonine-protein kinase, } \\
\text { putative, expressed }\end{array}$ & 0.56968 & 0.965738 & -1.17005 & -0.49038 & -0.34683 & -0.6278 \\
\hline LOC_Os02g 27480 & $\begin{array}{l}\text { membrane attack complex } \\
\text { component/perforin/complement } \\
\mathrm{C} 9 \text {, putative, expressed }\end{array}$ & 0.054664 & 0.847496 & -1.20102 & 0.06561 & 0.325275 & 1.9167 \\
\hline LOC_Os08g24190 & $\begin{array}{l}\text { OsFBX286 - F-box domain } \\
\text { containing protein, expressed }\end{array}$ & 1.075303 & 0.984956 & -1.31262 & -0.07762 & 0.975625 & \\
\hline LOC_Os04g40630 & $\begin{array}{l}\text { BTBZ4 - Bric-a-Brac, Tramtrack, } \\
\text { Broad Complex BTB domain with } \\
\text { TAZ zinc finger and } \\
\text { Calmodulin-binding domains, } \\
\text { expressed }\end{array}$ & 1.218921 & 1.31717 & -1.3625 & -0.46337 & 1.187875 & 2.96815 \\
\hline LOC_Os11g36510 & $\begin{array}{l}\text { retrotransposon protein, putative, } \\
\text { unclassified, expressed }\end{array}$ & 1.221531 & 1.316739 & -1.39647 & 0.389854 & 0.567038 & \\
\hline LOC_Os05g50380 & $\begin{array}{l}\text { glucose-1-phosphate } \\
\text { adenylyltransferase large subunit, } \\
\text { chloroplast precursor, putative, } \\
\text { expressed }\end{array}$ & 0.581913 & 1.038034 & -1.45629 & -0.15622 & 2.4029 & -0.5485 \\
\hline LOC_Os08g23960 & $\begin{array}{l}\text { OsFBL46 - F-box domain and LRR } \\
\text { containing protein, expressed }\end{array}$ & 0.74187 & 1.097278 & -1.49533 & -0.032 & -0.05131 & \\
\hline LOC_Os03g56160 & $\begin{array}{l}\text { lectin-like receptor kinase } 7 \text {, } \\
\text { putative, expressed }\end{array}$ & -0.45436 & 1.613115 & -1.55169 & 0.8599 & 0.85475 & \\
\hline LOC_Os08g19200 & expressed protein & 0.864661 & 1.090907 & -1.6212 & & & \\
\hline LOC_Os08g 35160 & $\begin{array}{l}\text { heat shock protein DnaJ, putative, } \\
\text { expressed }\end{array}$ & 0.333641 & 1.991116 & -1.84475 & 0.934194 & -0.64553 & 0.05065 \\
\hline LOC_Os01g65610 & expressed protein & 0.470391 & 0.120046 & 3.104297 & & & \\
\hline LOC_Os07g32710 & $\begin{array}{l}\text { retrotransposon protein, putative, } \\
\text { unclassified, expressed }\end{array}$ & 2.366842 & 0.460799 & 3.02609 & 0.03042 & 0.130313 & 0.63045 \\
\hline LOC_Os02g41680 & $\begin{array}{l}\text { phenylalanine ammonia-lyase, } \\
\text { putative, expressed }\end{array}$ & -0.08075 & 0.469767 & 2.752294 & 0.605036 & -0.784 & 3.60465 \\
\hline LOC_Os03g52390 & $\begin{array}{l}\text { PIII1 - Proteinase inhibitor II family } \\
\text { protein precursor, expressed }\end{array}$ & 0.230628 & 0.591478 & 2.455296 & 1.283272 & 2.066 & 2.4384 \\
\hline
\end{tabular}




\begin{tabular}{|c|c|c|c|c|c|c|c|}
\hline LOC_Os04g02490 & expressed protein & 0.25447 & 0.202314 & 2.380529 & -0.06247 & 0.628363 & \\
\hline LOC_Os01g10890 & $\begin{array}{l}\text { CAMK_KIN1/SNF1/Nim1_like.8 - } \\
\text { CAMK includes } \\
\text { calcium/calmodulin depedent } \\
\text { protein kinases, expressed }\end{array}$ & 0.159278 & 0.008341 & 2.325187 & -1.12806 & -2.08753 & \\
\hline LOC_Os01g17396 & expressed protein & -0.07005 & -0.15031 & 2.183089 & -0.0582 & 0.07315 & 0.1159 \\
\hline LOC_Os07g18990 & $\begin{array}{l}\text { LTPL40 - Protease inhibitor/seed } \\
\text { storage/LTP family protein } \\
\text { precursor, expressed }\end{array}$ & -0.22407 & -0.33285 & 2.164805 & -0.38161 & -1.30263 & 0.7675 \\
\hline LOC_Os06g05230 & $\begin{array}{l}\text { retrotransposon protein, putative, } \\
\text { unclassified, expressed }\end{array}$ & 0.091616 & 0.316795 & 2.159462 & & & \\
\hline LOC_Os04g31120 & $\begin{array}{l}\text { OsFBK14 - F-box domain and kelch } \\
\text { repeat containing protein, expressed }\end{array}$ & -0.4348 & -0.57179 & 2.109069 & 0.755325 & -0.24233 & \\
\hline LOC_Os03g60580 & $\begin{array}{l}\text { actin-depolymerizing factor, } \\
\text { putative, expressed }\end{array}$ & 0.309457 & -0.25407 & 2.013691 & 0.239195 & 0.573875 & \\
\hline LOC_Os08g33710 & $\begin{array}{l}\text { ribonuclease } \mathrm{T} 2 \text { family domain } \\
\text { containing protein, expressed }\end{array}$ & 0.141643 & 0.123274 & 1.99959 & -0.825 & -0.47701 & 0.15635 \\
\hline LOC_Os06g51060 & $\begin{array}{l}\text { CHIT8 - Chitinase family protein } \\
\text { precursor, expressed }\end{array}$ & 0.022889 & -0.1662 & 1.999407 & 1.16594 & 1.0355 & 1.2868 \\
\hline LOC_Os03g57880 & $\begin{array}{l}\text { glucan endo-1,3-beta-glucosidase } \\
\text { precursor, putative, expressed }\end{array}$ & 0.285945 & 0.034413 & 1.975122 & -0.39709 & 1.774225 & \\
\hline LOC_Os08g06110 & $\begin{array}{l}\text { MYB family transcription factor, } \\
\text { putative, expressed }\end{array}$ & -0.37638 & -0.1035 & 1.942447 & -0.24468 & -0.95353 & -0.17155 \\
\hline LOC_Os04g46880 & $\begin{array}{l}\text { transporter, major facilitator family, } \\
\text { putative, expressed }\end{array}$ & -0.1387 & 0.364692 & 1.908629 & -0.16371 & -0.86968 & 2.07555 \\
\hline LOC_Os08g39140 & $\begin{array}{l}\text { heat shock protein, putative, } \\
\text { expressed }\end{array}$ & -0.57939 & 0.006477 & 1.851955 & -0.05243 & 0.817625 & -0.5244 \\
\hline LOC_Os03g13540 & $\begin{array}{l}\text { Ser/Thr protein phosphatase family } \\
\text { protein, putative, expressed }\end{array}$ & -0.23539 & 0.261718 & 1.837805 & -1.66641 & 1.912375 & 1.06805 \\
\hline LOC_Os12g38660 & expressed protein & 0.700296 & 0.327909 & 1.823683 & -0.48384 & -0.67675 & -0.3479 \\
\hline LOC_Os01g55540 & $\begin{array}{l}\text { aminotransferase, classes I and II, } \\
\text { domain containing protein, } \\
\text { expressed }\end{array}$ & -0.41636 & 0.276277 & 1.802218 & 0.043507 & 0.942375 & -0.288 \\
\hline LOC_Os01g09570 & $\begin{array}{l}\text { 6-phosphofructokinase, putative, } \\
\text { expressed }\end{array}$ & -0.53747 & 0.003369 & 1.774486 & -0.11409 & 0.32325 & \\
\hline LOC_Os05g04610 & $\begin{array}{l}\text { ABC transporter, ATP-binding } \\
\text { protein, putative, expressed }\end{array}$ & -0.31227 & -0.33239 & 1.738652 & -0.6838 & -2.72748 & 1.24895 \\
\hline LOC_Os03g48190 & expressed protein & 0.239911 & -0.0995 & 1.72994 & 0.246745 & -0.68351 & 0.11565 \\
\hline LOC_Os03g12290 & $\begin{array}{l}\text { glutamine synthetase, catalytic } \\
\text { domain containing protein, } \\
\text { expressed }\end{array}$ & -0.06426 & 0.288342 & 1.722727 & 0.189553 & -0.528 & \\
\hline LOC_Os03g39760 & $\begin{array}{l}\text { cytochrome P450, putative, } \\
\text { expressed }\end{array}$ & -0.13983 & -0.0365 & 1.712995 & 0.030716 & -3.26888 & 0.86205 \\
\hline LOC_Os03g37840 & $\begin{array}{l}\text { potassium transporter, putative, } \\
\text { expressed }\end{array}$ & -0.5234 & 0.5539 & 1.712992 & 0.41608 & -1.66333 & 0.38685 \\
\hline LOC_Os01g31100 & $\begin{array}{l}\text { retrotransposon, putative, } \\
\text { centromere-specific }\end{array}$ & 0.340402 & -0.14551 & 1.698301 & & & \\
\hline LOC_Os03g49630 & expressed protein & -0.29505 & -0.01083 & 1.69613 & 0.277418 & -2.46779 & 0.29455 \\
\hline LOC_Os03g52370 & $\begin{array}{l}\text { PIII4 - Proteinase inhibitor II family } \\
\text { protein precursor, expressed }\end{array}$ & -0.03898 & 0.065326 & 1.676255 & 0.361409 & 0.537638 & 1.3359 \\
\hline LOC_Os02g57060 & $\begin{array}{l}\text { OsCttP2 - Putative C-terminal } \\
\text { processing peptidase homologue, } \\
\text { expressed }\end{array}$ & -0.15097 & -0.14081 & 1.669211 & -0.08294 & -1.23544 & -0.1757 \\
\hline LOC_Os05g50840 & $\begin{array}{l}\text { mitochondrial carrier protein, } \\
\text { putative, expressed }\end{array}$ & -0.14442 & -0.07275 & 1.664499 & 0.203986 & -0.00413 & \\
\hline
\end{tabular}




\begin{tabular}{|c|c|c|c|c|c|c|c|}
\hline LOC_Os03g05290 & $\begin{array}{l}\text { aquaporin protein, putative, } \\
\text { expressed }\end{array}$ & 0.117806 & -0.4643 & 1.649945 & -0.79695 & 0.18525 & \\
\hline LOC_Os06g01760 & ligA, putative, expressed & -0.43976 & -0.45435 & 1.649658 & -0.15805 & -0.775 & \\
\hline LOC_Os04g58710 & $\begin{array}{l}\text { AMP-binding domain containing } \\
\text { protein, expressed }\end{array}$ & 0.580699 & -0.07495 & 1.646555 & 1.463947 & -0.10675 & 0.8732 \\
\hline LOC_Os03g55240 & $\begin{array}{l}\text { cytochrome P450, putative, } \\
\text { expressed }\end{array}$ & -0.07001 & -0.33214 & 1.64239 & 0.099796 & -0.31638 & 0.52395 \\
\hline LOC_Os01g52230 & $\begin{array}{l}\text { phosphoethanolamine/phosphocholi } \\
\text { ne phosphatase, putative, expressed }\end{array}$ & 0.307707 & 0.16564 & 1.630064 & -2.15971 & 0.68415 & 1.4454 \\
\hline LOC_Os11g36180 & receptor kinase, putative, expressed & -0.40071 & -0.02072 & 1.623519 & & & \\
\hline LOC_Os08g14950 & $\begin{array}{l}\text { receptor-like protein kinase } 2 \\
\text { precursor, putative, expressed }\end{array}$ & -0.00724 & -0.1331 & 1.604925 & & & \\
\hline LOC_Os07g42250 & $\begin{array}{l}\text { strictosidine synthase, putative, } \\
\text { expressed }\end{array}$ & -0.29293 & -0.22317 & 1.60161 & -0.21389 & -1.88511 & -0.0833 \\
\hline LOC_Os01g04920 & $\begin{array}{l}\text { glycosyl transferase, group } 1 \\
\text { domain containing protein, } \\
\text { expressed }\end{array}$ & -0.42365 & 0.496614 & 1.591279 & -1.73096 & -1.63008 & -1.49295 \\
\hline LOC_Os06g 21890 & $\begin{array}{l}\text { basic proline-rich protein precursor, } \\
\text { putative, expressed }\end{array}$ & -0.28882 & 0.199713 & 1.578644 & 0.077735 & -0.15604 & 0.6951 \\
\hline LOC_Os06g03860 & $\begin{array}{l}\text { uncharacterized membrane protein, } \\
\text { putative, expressed }\end{array}$ & 0.219387 & -0.24087 & 1.576973 & -0.28168 & 0.111275 & \\
\hline LOC_Os07g43940 & $\begin{array}{l}\text { X8 domain containing protein, } \\
\text { expressed }\end{array}$ & -0.08947 & -0.07741 & 1.575404 & -0.17198 & -0.39713 & -0.0486 \\
\hline LOC_Os11g08670 & NAD kinase, putative, expressed & -0.47924 & -0.41816 & 1.569675 & 0.224285 & -0.62188 & 0.04455 \\
\hline LOC_Os03g19290 & $\begin{array}{l}\text { mitochondrial import inner } \\
\text { membrane translocase subunit } \\
\text { Tim17, putative, expressed }\end{array}$ & 0.020656 & -0.29482 & 1.565506 & 0.149452 & -0.19608 & -0.6073 \\
\hline LOC_Os01g56360 & wax synthase, putative, expressed & 0.019516 & -0.27605 & 1.559191 & -0.1878 & -1.33109 & \\
\hline LOC_Os03g52170 & $\begin{array}{l}\text { 4-hydroxy-3-methylbut-2-enyl } \\
\text { diphosphate reductase, putative, } \\
\text { expressed }\end{array}$ & -0.25606 & 0.208098 & 1.558048 & -0.52021 & -0.033 & \\
\hline LOC_Os08g34210 & $\begin{array}{l}\text { aldehyde dehydrogenase, putative, } \\
\text { expressed }\end{array}$ & -0.12576 & -0.42752 & 1.545683 & -0.27298 & -1.59188 & -0.22315 \\
\hline LOC_Os02g54140 & $\begin{array}{l}\text { hsp20/alpha crystallin family } \\
\text { protein, putative, expressed }\end{array}$ & -0.04761 & -0.26412 & 1.542395 & -1.03339 & -1.23978 & 0.0633 \\
\hline LOC_Os01g62840 & $\begin{array}{l}\text { mannose-1-phosphate } \\
\text { guanyltransferase, putative, } \\
\text { expressed }\end{array}$ & -0.27282 & -0.04399 & 1.540741 & 0.508205 & -0.15783 & 0.15685 \\
\hline LOC_Os01g07370 & KIP1, putative, expressed & -0.38016 & 0.565146 & 1.54032 & 0.762761 & 0.480625 & -0.6225 \\
\hline LOC_Os02g58100 & expressed protein & 0.249995 & -0.03633 & 1.535223 & -0.2254 & -1.115 & \\
\hline LOC_Os09g38070 & expressed protein & -0.47433 & -0.72867 & 1.524207 & -0.51424 & -0.63388 & 0.4403 \\
\hline LOC_Os01g08560 & $\begin{array}{l}\text { DnaK family protein, putative, } \\
\text { expressed }\end{array}$ & -0.4394 & 0.222786 & 1.513481 & -0.25983 & 0.203038 & -0.13045 \\
\hline LOC_Os $04 \mathrm{~g} 45360$ & $\begin{array}{l}\text { retrotransposon protein, putative, } \\
\text { unclassified, expressed }\end{array}$ & -0.46935 & -0.86578 & 1.510922 & & & \\
\hline LOC_Os04g54230 & $\begin{array}{l}\text { wound induced protein, putative, } \\
\text { expressed }\end{array}$ & -0.3721 & -0.30099 & 1.501586 & 0.008147 & 0.4178 & 0.88065 \\
\hline LOC_Os01g15900 & expressed protein & -0.22287 & -0.22212 & 1.496699 & 0.831606 & -0.54308 & 0.243 \\
\hline LOC_Os01g45460 & serine esterase, putative, expressed & -0.01954 & -0.09801 & 1.486874 & -0.11684 & -0.08374 & 0.40295 \\
\hline LOC_Os11g43860 & $\begin{array}{l}\text { sodium/calcium exchanger protein, } \\
\text { putative, expressed }\end{array}$ & -0.29585 & 0.520314 & 1.480552 & 0.459985 & 0.08165 & 0.3121 \\
\hline LOC_Os09g06499 & $\begin{array}{l}\text { sulfate transporter } 4.1 \text {, chloroplast } \\
\text { precursor, putative, expressed }\end{array}$ & -0.49266 & -0.06766 & 1.47355 & -0.11393 & -0.26435 & 0.07215 \\
\hline LOC_Os06g05630 & $\begin{array}{l}\text { GDSL-like lipase/acylhydrolase, } \\
\text { putative, expressed }\end{array}$ & 0.563935 & -0.22254 & 1.464149 & -0.71512 & -1.1426 & 0.06435 \\
\hline
\end{tabular}




\begin{tabular}{|c|c|c|c|c|c|c|c|}
\hline LOC_Os01g71340 & $\begin{array}{l}\text { glycosyl hydrolases family } 17, \\
\text { putative, expressed }\end{array}$ & -0.29051 & 0.305427 & 1.457615 & 0.61339 & 4.36325 & 1.1184 \\
\hline LOC_Os07g37560 & myosin- $\mathrm{Vb}$, putative, expressed & 0.021894 & 0.168476 & 1.451504 & -0.10787 & -0.20688 & \\
\hline LOC_Os12g32760 & $\begin{array}{l}\text { transporter family protein, putative, } \\
\text { expressed }\end{array}$ & -0.17724 & -0.20521 & 1.43865 & 0.052844 & -0.21798 & \\
\hline LOC_Os12g43340 & $\begin{array}{l}\text { actin-depolymerizing factor, } \\
\text { putative, expressed }\end{array}$ & 0.235272 & 0.287315 & 1.434862 & -0.44723 & -0.8392 & \\
\hline LOC_Os03g43870 & expressed protein & -0.00237 & -0.75916 & 1.430551 & & & \\
\hline LOC_Os08g14940 & receptor kinase, putative, expressed & -0.10012 & 0.398548 & 1.426802 & -0.03314 & -0.34788 & \\
\hline LOC_Os02g31030 & $\begin{array}{l}\text { glycerophosphoryl diester } \\
\text { phosphodiesterase family protein, } \\
\text { putative, expressed }\end{array}$ & 0.415283 & 0.412523 & 1.426115 & -1.85783 & -0.29829 & 2.62115 \\
\hline LOC_Os02g29510 & $\begin{array}{l}\text { DUF803 domain containing, } \\
\text { putative, expressed }\end{array}$ & 0.166694 & 0.183054 & 1.423737 & -0.19935 & -1.16695 & -0.55855 \\
\hline LOC_Os03g43720 & $\begin{array}{l}\text { transporter family protein, putative, } \\
\text { expressed }\end{array}$ & 0.119785 & -0.02671 & 1.42368 & -0.14075 & 0.336963 & 0.21255 \\
\hline LOC_Os04g46960 & $\begin{array}{l}\text { glutathione peroxidase domain } \\
\text { containing protein, expressed }\end{array}$ & -0.03305 & 0.131359 & 1.412068 & 0.387975 & 0.459375 & 0.40885 \\
\hline LOC_Os03g21890 & $\begin{array}{l}\text { potassium transporter, putative, } \\
\text { expressed }\end{array}$ & -0.19303 & -0.09029 & 1.410098 & -0.19149 & -0.4482 & \\
\hline LOC_Os01g14900 & $\begin{array}{l}\text { glycerol-3-phosphate } \\
\text { acyltransferase, putative, expressed }\end{array}$ & 0.11633 & 0.130731 & 1.40459 & -0.00518 & 0.242525 & \\
\hline LOC_Os03g08430 & $\begin{array}{l}\text { SAC domain containing protein, } \\
\text { putative, expressed }\end{array}$ & -0.22198 & -0.14205 & 1.403178 & -0.07642 & 0.337313 & 1.55945 \\
\hline LOC_Os05g41930 & N-rich protein, putative, expressed & -0.5814 & -0.4815 & 1.393921 & -0.01852 & -0.17213 & -0.0705 \\
\hline LOC_Os $12 \mathrm{~g} 31850$ & $\begin{array}{l}\text { ureide permease, putative, } \\
\text { expressed }\end{array}$ & 0.237948 & -0.68813 & 1.387038 & -0.11175 & 0.505075 & 0.60795 \\
\hline LOC_Os04g23890 & $\begin{array}{l}\text { AGC_PVPK_like_kin82y.10 - ACG } \\
\text { kinases include homologs to PKA, } \\
\text { PKG and PKC, expressed }\end{array}$ & -0.43627 & -0.563 & 1.38335 & -0.01447 & -1.83238 & 0.1493 \\
\hline LOC_Os03g20730 & $\begin{array}{l}\text { chaperone protein dnaJ, putative, } \\
\text { expressed }\end{array}$ & -0.2423 & -0.16449 & 1.383296 & 1.308946 & -0.45438 & 0.0888 \\
\hline LOC_Os04g54300 & $\begin{array}{l}\text { wound induced protein, putative, } \\
\text { expressed }\end{array}$ & 0.057619 & -0.2692 & 1.382769 & 0.397519 & 0.66075 & \\
\hline LOC_Os03g17800 & $\begin{array}{l}\text { phosphatidylinositol transfer protein } \\
\text { alpha isoform, putative, expressed }\end{array}$ & -0.08126 & 0.197204 & 1.371122 & -1.16267 & 0.371613 & 0.0953 \\
\hline LOC_Os01g67320 & expressed protein & 0.227811 & 0.015442 & 1.366539 & 0.105538 & -1.24725 & 0.194 \\
\hline LOC_Os02g42940 & $\begin{array}{l}\text { MSP domain containing protein, } \\
\text { expressed }\end{array}$ & -0.18089 & -0.0881 & 1.363976 & -0.11135 & -0.4437 & 0.59285 \\
\hline LOC_Os03g43100 & expressed protein & 0.962316 & 0.447866 & 1.359162 & 4.370815 & 0.016788 & -0.31555 \\
\hline LOC_Os09g09930 & $\begin{array}{l}\text { heavy metal transport/detoxification } \\
\text { protein, putative, expressed }\end{array}$ & -0.02987 & -0.12745 & 1.355495 & -0.24259 & -1.8946 & 0.0623 \\
\hline LOC_Os03g03510 & $\begin{array}{l}\text { CAMK_KIN1/SNF1/Nim1_like.15 } \\
\text {-CAMK includes } \\
\text { calcium/calmodulin depedent } \\
\text { protein kinases, expressed }\end{array}$ & 0.315179 & -0.21288 & 1.353872 & 0.02246 & 0.057588 & \\
\hline LOC_Os01g62810 & $\begin{array}{l}\text { regulator of chromosome } \\
\text { condensation, putative, expressed }\end{array}$ & 0.480613 & 0.16726 & 1.349774 & 0.002758 & 0.553313 & -0.44225 \\
\hline LOC_Os08g29720 & $\begin{array}{l}\text { mitochondrial carrier protein, } \\
\text { putative, expressed }\end{array}$ & -0.28508 & 0.59744 & 1.346159 & 0.214802 & -0.14433 & -0.2947 \\
\hline LOC_Os04g35840 & $\begin{array}{l}\text { T-complex protein } 11 \text {, putative, } \\
\text { expressed }\end{array}$ & -0.38842 & 0.111143 & 1.345561 & -0.0359 & 0.2115 & -0.48625 \\
\hline LOC_Os08g02860 & $\begin{array}{l}\text { transposon protein, putative, } \\
\text { unclassified, expressed }\end{array}$ & -0.01801 & 0.034977 & 1.343484 & 0.074998 & -0.27975 & 1.1677 \\
\hline
\end{tabular}




\begin{tabular}{|c|c|c|c|c|c|c|c|}
\hline LOC_Os10g41780 & $\begin{array}{l}\text { chlorophyllide a oxygenase, } \\
\text { chloroplast precursor, putative, } \\
\text { expressed }\end{array}$ & 0.055264 & -0.22434 & 1.340079 & -0.83212 & -1.60838 & \\
\hline LOC_Os06g13560 & $\begin{array}{l}\text { SAM dependent carboxyl } \\
\text { methyltransferase, putative, } \\
\text { expressed }\end{array}$ & 0.112941 & 0.511587 & 1.339616 & 0.803892 & 4.82265 & 0.0075 \\
\hline LOC_Os07g35510 & $\begin{array}{l}\text { glucan endo-1,3-beta-glucosidase } \\
\text { precursor, putative, expressed }\end{array}$ & -0.56113 & -0.29182 & 1.334085 & 0.546757 & 1.568875 & -0.00225 \\
\hline LOC_Os01g28770 & hypothetical protein & -0.15015 & -0.19693 & 1.332129 & & & \\
\hline LOC_Os05g30250 & $\begin{array}{l}\text { Os5bglu19 - beta-glucosidase } \\
\text { homologue, similar to G. max } \\
\text { isohydroxyurate hydrolase, } \\
\text { expressed }\end{array}$ & 0.071367 & 0.087921 & 1.32999 & -0.14677 & -1.63395 & 0.9521 \\
\hline LOC_Os07g22690 & expressed protein & 0.12094 & -0.21474 & 1.322673 & & & \\
\hline LOC_Os01g09320 & $\begin{array}{l}\text { NADP-dependent malic enzyme, } \\
\text { chloroplast precursor, putative, } \\
\text { expressed }\end{array}$ & 0.09046 & 0.424401 & 1.32228 & -0.23099 & -0.14514 & \\
\hline LOC_Os04g48860 & hypothetical protein & -0.03147 & 0.162068 & 1.322139 & -0.70628 & -1.67025 & -0.4471 \\
\hline LOC_Os02g03860 & $\begin{array}{l}\text { mitochondrial ATP synthase } \\
\text { precursor, putative, expressed }\end{array}$ & -0.43355 & -0.13614 & 1.322057 & -0.04703 & 0.27 & -0.061 \\
\hline LOC_Os04g23440 & $\begin{array}{l}\text { helix-loop-helix DNA-binding } \\
\text { domain containing protein, } \\
\text { expressed }\end{array}$ & -0.56276 & 0.30396 & 1.320267 & & & \\
\hline LOC_Os08g33750 & $\begin{array}{l}\text { myb-like DNA-binding domain } \\
\text { containing protein, expressed }\end{array}$ & -0.37054 & -0.06583 & 1.317998 & -0.27326 & -0.98398 & -0.0077 \\
\hline LOC_Os03g06240 & $\begin{array}{l}\text { YT521-B-like family domain } \\
\text { containing protein, expressed }\end{array}$ & -0.58694 & 0.243364 & 1.316985 & -0.08421 & -0.40175 & -0.0477 \\
\hline LOC_Os01g22010 & $\begin{array}{l}\text { S-adenosylmethionine synthetase, } \\
\text { putative, expressed }\end{array}$ & -0.06022 & 0.411495 & 1.314552 & 0.395094 & 0.426625 & 0.26425 \\
\hline LOC_Os09g30414 & $\begin{array}{l}\text { aspartic proteinase nepenthesin-2 } \\
\text { precursor, putative, expressed }\end{array}$ & 0.032302 & -0.45264 & 1.311794 & 0.119275 & -0.0715 & 1.7456 \\
\hline LOC_Os04g58110 & pyruvate kinase, putative, expressed & -0.511 & 0.09382 & 1.304513 & -0.22783 & 0.33375 & 0.1368 \\
\hline LOC_Os02g04710 & $\begin{array}{l}\text { cycloartenol synthase, putative, } \\
\text { expressed }\end{array}$ & 0.18135 & 0.378945 & 1.293952 & -0.17863 & -0.26063 & \\
\hline LOC_Os01g11240 & $\begin{array}{l}\text { DUF538 domain containing protein, } \\
\text { putative, expressed }\end{array}$ & 0.289558 & -0.12975 & 1.293233 & -0.23991 & -0.08825 & 0.3005 \\
\hline LOC_Os10g22430 & $\begin{array}{l}\text { gibberellin response modulator } \\
\text { protein, putative, expressed }\end{array}$ & -0.19887 & -0.29667 & 1.289106 & 0.02698 & -0.15163 & 0.1432 \\
\hline LOC_Os09g06464 & $\begin{array}{l}\mathrm{CCT} / \mathrm{B} \text {-box zinc finger protein, } \\
\text { putative, expressed }\end{array}$ & 0.289411 & 0.009049 & 1.283868 & -0.36088 & -0.9599 & \\
\hline LOC_Os10g35560 & expressed protein & -0.39459 & 0.074125 & 1.277643 & 0.099433 & 0.20225 & 0.2122 \\
\hline LOC_Os08g30790 & $\begin{array}{l}\text { hypersensitive-induced response } \\
\text { protein, putative, expressed }\end{array}$ & -0.50303 & -0.47608 & 1.275392 & -0.01632 & -0.42965 & 0.19765 \\
\hline LOC_Os03g09020 & dehydrogenase, putative, expressed & -0.25692 & -0.27869 & 1.271753 & 0.523695 & 0.081625 & 1.74675 \\
\hline LOC_Os03g49050 & $\begin{array}{l}\text { possible lysine decarboxylase } \\
\text { domain containing protein, } \\
\text { expressed }\end{array}$ & 0.242084 & 0.029849 & 1.271703 & -0.21973 & 0.045113 & \\
\hline LOC_Os01g14410 & $\begin{array}{l}\text { early light-induced protein, } \\
\text { chloroplast precursor, putative, } \\
\text { expressed }\end{array}$ & -0.23578 & 0.001652 & 1.270832 & -0.38573 & -1.97991 & 0.2953 \\
\hline LOC_Os09g36620 & hypothetical protein & -0.24041 & -0.32582 & 1.269612 & & & \\
\hline LOC_Os06g39900 & $\begin{array}{l}\text { agenet domain containing protein, } \\
\text { putative, expressed }\end{array}$ & -0.12052 & -0.38212 & 1.269401 & -0.39862 & -0.48971 & 0.13125 \\
\hline LOC_Os05g51370 & hypothetical protein & -0.06281 & 0.105053 & 1.264357 & & & \\
\hline LOC_Os12g22510 & $\begin{array}{l}\text { retrotransposon protein, putative, } \\
\text { Ty3-gypsy subclass }\end{array}$ & -0.09809 & -0.08304 & 1.264134 & & & \\
\hline
\end{tabular}




\begin{tabular}{|c|c|c|c|c|c|c|c|}
\hline LOC_Os02g01060 & $\begin{array}{l}\text { harpin-induced protein } 1 \text { domain } \\
\text { containing protein, expressed }\end{array}$ & -0.44587 & 0.06355 & 1.260665 & -0.40334 & -0.78301 & -0.31735 \\
\hline LOC_Os11g41150 & $\begin{array}{l}\text { nitrilase-associated protein, } \\
\text { putative, expressed }\end{array}$ & 0.234155 & -0.18725 & 1.259466 & -0.75189 & 2.310488 & -0.47235 \\
\hline LOC_Os03g59320 & expressed protein & -0.09846 & 0.057192 & 1.259103 & -0.16604 & 0.78825 & 1.61625 \\
\hline LOC_Os12g37650 & $\begin{array}{l}\text { DUF538 domain containing protein, } \\
\text { putative, expressed }\end{array}$ & -0.10336 & -0.43799 & 1.258531 & 0.006814 & -1.63746 & -0.49895 \\
\hline LOC_Os07g48160 & $\begin{array}{l}\text { alpha-galactosidase precursor, } \\
\text { putative, expressed }\end{array}$ & -0.08042 & -0.1902 & 1.256744 & -0.33812 & 1.25815 & \\
\hline LOC_Os01g63380 & $\begin{array}{l}\text { transposon protein, putative, } \\
\text { unclassified, expressed }\end{array}$ & 0.325032 & 0.238514 & 1.25066 & & & \\
\hline LOC_Os02g57790 & $\begin{array}{l}\text { ZOS2-19 - C2H2 zinc finger } \\
\text { protein, expressed }\end{array}$ & -0.0853 & -0.14267 & 1.250554 & & & \\
\hline LOC_Os12g03060 & expressed protein & -0.36405 & -0.4763 & 1.243288 & 0.075722 & 0.58375 & 0.09805 \\
\hline LOC_Os01g56780 & $\begin{array}{l}\text { plus- } 3 \text { domain containing protein, } \\
\text { expressed }\end{array}$ & -0.37727 & 0.35635 & 1.239628 & -0.2439 & -0.59638 & -0.36155 \\
\hline LOC_Os10g31640 & $\begin{array}{l}\text { glycine-rich cell wall structural } \\
\text { protein } 2 \text { precursor, putative, } \\
\text { expressed }\end{array}$ & 0.341043 & -0.26132 & 1.237072 & -0.13426 & 0.0063 & \\
\hline LOC_Os $12 \mathrm{~g} 04020$ & $\begin{array}{l}\text { hydroxymethylglutaryl-CoA lyase, } \\
\text { putative, expressed }\end{array}$ & -0.4664 & -0.17888 & 1.233948 & -0.18859 & 0.67025 & 1.6773 \\
\hline LOC_Os02g16040 & $\begin{array}{l}\text { ubiquitin-conjugating enzyme, } \\
\text { putative, expressed }\end{array}$ & 0.042054 & 0.244525 & 1.232284 & 0.024861 & 1.393125 & \\
\hline LOC_Os01g12810 & $\begin{array}{l}\text { retrotransposon protein, putative, } \\
\text { unclassified, expressed }\end{array}$ & 0.154694 & 0.294055 & 1.2313 & 0.276908 & -1.74551 & 0.04975 \\
\hline LOC_Os03g42810 & $\begin{array}{l}\text { endonuclease/exonuclease/phosphat } \\
\text { ase family domain containing } \\
\text { protein, expressed }\end{array}$ & 0.500267 & 0.310071 & 1.230129 & 0.070647 & 1.68855 & \\
\hline LOC_Os01g68330 & $\begin{array}{l}\text { antigen peptide transporter-like } 1 \text {, } \\
\text { chloroplast precursor, putative, } \\
\text { expressed }\end{array}$ & -0.03351 & -0.62467 & 1.228882 & -0.34221 & 0.13445 & 0.4354 \\
\hline LOC_Os06g45350 & $\begin{array}{l}\text { protein kinase domain containing } \\
\text { protein, expressed }\end{array}$ & 0.047958 & 0.314365 & 1.226662 & -0.433 & 1.447375 & -0.2465 \\
\hline LOC_Os07g39900 & $\begin{array}{l}\text { interferon-related developmental } \\
\text { regulator, putative, expressed }\end{array}$ & -0.39919 & -0.17935 & 1.226136 & -0.55571 & 0.353375 & -0.4126 \\
\hline LOC_Os06g40120 & $\begin{array}{l}\text { SPX domain containing protein, } \\
\text { putative, expressed }\end{array}$ & -0.35321 & 0.316101 & 1.221792 & -0.26056 & -0.83714 & 0.1464 \\
\hline LOC_Os01g18080 & $\begin{array}{l}\text { retrotransposon protein, putative, } \\
\text { unclassified, expressed }\end{array}$ & -0.29719 & -0.53398 & 1.221785 & 0.534189 & 1.18875 & 0.4055 \\
\hline LOC_Os05g50500 & $\begin{array}{l}\text { secretory protein, putative, } \\
\text { expressed }\end{array}$ & -0.17277 & -0.22007 & 1.220852 & -0.13186 & -0.64946 & \\
\hline LOC_Os07g48630 & $\begin{array}{l}\text { ethylene-insensitive } 3 \text {, putative, } \\
\text { expressed }\end{array}$ & -0.50258 & -0.21481 & 1.220723 & 1.046094 & 0.911375 & 1.56175 \\
\hline LOC_Os01g58640 & $\begin{array}{l}\text { nucleotide } \\
\text { pyrophosphatase/phosphodiesterase, } \\
\text { putative, expressed }\end{array}$ & -0.31399 & 0.033456 & 1.219181 & -1.25104 & -1.26933 & -0.69095 \\
\hline LOC_Os06g18990 & $\begin{array}{l}\text { embryogenesis transmembrane } \\
\text { protein, putative, expressed }\end{array}$ & -0.27091 & -0.07965 & 1.217188 & -0.24976 & -0.34878 & 0.22385 \\
\hline LOC_Os01g47630 & expressed protein & -0.29105 & 0.140064 & 1.216656 & -0.26661 & -0.63484 & \\
\hline LOC_Os03g31230 & $\begin{array}{l}\text { MYB family transcription factor, } \\
\text { putative, expressed }\end{array}$ & -0.55293 & -0.30742 & 1.215568 & -0.13181 & -0.0502 & 0.54205 \\
\hline LOC_Os08g39150 & expressed protein & -0.41377 & 0.320661 & 1.213102 & -0.32646 & 0.110375 & 0.2091 \\
\hline LOC_Os03g61090 & expressed protein & 0.048187 & -0.49068 & 1.210753 & 0.078606 & -2.35795 & \\
\hline LOC_Os02g44870 & dehydrin, putative, expressed & 0.181634 & -0.19167 & 1.206707 & 0.035625 & -0.15905 & -0.01905 \\
\hline LOC_Os12g09480 & $\begin{array}{l}\text { retrotransposon protein, putative, } \\
\text { Ty3-gypsy subclass, expressed }\end{array}$ & -0.37801 & -0.08338 & 1.206474 & & & \\
\hline
\end{tabular}




\begin{tabular}{|c|c|c|c|c|c|c|c|}
\hline LOC_Os02g36490 & expressed protein & 0.328013 & 0.050174 & 1.20632 & 0.610348 & 0.39645 & \\
\hline LOC_Os12g29520 & $\begin{array}{l}\text { auxin response factor, putative, } \\
\text { expressed }\end{array}$ & -0.53621 & -0.42738 & 1.205519 & 0.132073 & -0.07775 & \\
\hline LOC_Os12g44230 & expressed protein & -0.51668 & 0.325442 & 1.20443 & 0.348358 & -0.17848 & -0.0803 \\
\hline LOC_Os04g31390 & $\begin{array}{l}\text { vacuolar protein sorting-associated } \\
\text { protein } 11 \text {, putative, expressed }\end{array}$ & 0.384655 & 0.106093 & 1.203065 & 0.02966 & 0.034625 & 0.30625 \\
\hline LOC_Os09g02270 & $\begin{array}{l}\text { cyclase family protein, putative, } \\
\text { expressed }\end{array}$ & 0.986741 & -0.50003 & 1.199572 & 0.160669 & 0.315013 & 1.70195 \\
\hline LOC_Os07g02340 & expressed protein & 0.120101 & 0.211513 & 1.195652 & -0.249 & 0.470875 & 0.3318 \\
\hline LOC_Os01g13390 & expressed protein & 0.806562 & 0.578907 & 1.19308 & -0.56324 & -2.34364 & \\
\hline LOC_Os02g48720 & $\begin{array}{l}\text { mitochondrial carrier protein, } \\
\text { putative, expressed }\end{array}$ & -0.2503 & 0.307055 & 1.192688 & 0.116405 & 1.550125 & -0.01725 \\
\hline LOC_Os06g 28630 & expressed protein & -0.26872 & -0.51383 & 1.187432 & -0.22798 & -0.13634 & -0.1547 \\
\hline LOC_Os03g62240 & expressed protein & -0.19563 & -0.04657 & 1.183856 & -0.23968 & -1.12611 & 0.0731 \\
\hline LOC_Os05g39700 & hypothetical protein & -0.30074 & -0.03064 & 1.18192 & & & \\
\hline LOC_Os03g63580 & $\begin{array}{l}\text { phosphoesterase family protein, } \\
\text { putative, expressed }\end{array}$ & -0.17846 & -0.04959 & 1.180262 & -0.41344 & \#\#\#\#\#\#\# & \\
\hline LOC_Os06g49120 & $\begin{array}{l}\text { Complex I intermediate-associated } \\
\text { protein } 30 \text { domain containing }\end{array}$ & -0.30772 & -0.84889 & 1.179567 & 0.221483 & -2.39248 & \\
\hline LOC_Os04g13140 & $\begin{array}{l}\text { protein, putative, expressed } \\
\text { vignain precursor, putative, } \\
\text { expressed }\end{array}$ & -0.03917 & 0.047869 & 1.178027 & -0.00341 & 0.049675 & \\
\hline LOC_Os03g27310 & histone $\mathrm{H} 3$, putative, expressed & -0.39507 & 0.04916 & 1.176369 & -0.04195 & 0.134625 & 0.0209 \\
\hline LOC_Os11g06010 & $\begin{array}{l}\text { helix-loop-helix DNA-binding } \\
\text { protein, putative, expressed }\end{array}$ & -0.26898 & -0.12246 & 1.173904 & -0.04048 & 0.396475 & -0.8507 \\
\hline LOC_Os01g60830 & expressed protein & 0.897806 & 0.570377 & 1.170648 & -0.66755 & -1.74385 & \\
\hline LOC_Os07g44060 & $\begin{array}{l}\text { haloacid dehalogenase-like } \\
\text { hydrolase family protein, putative, } \\
\text { expressed }\end{array}$ & 0.433766 & 0.456103 & 1.170408 & -0.31247 & 0.295663 & \\
\hline LOC_Os03g19240 & $\begin{array}{l}\text { AMP-binding enzyme, putative, } \\
\text { expressed }\end{array}$ & -0.23764 & -0.00225 & 1.168932 & -0.16444 & -0.875 & \\
\hline LOC_Os01g53930 & hexokinase, putative, expressed & 0.044709 & -0.2552 & 1.164149 & -0.45172 & -0.32461 & \\
\hline LOC_Os05g02020 & $\begin{array}{l}\text { protein kinase APK1A, chloroplast } \\
\text { precursor, putative, expressed }\end{array}$ & -0.42971 & -0.58317 & 1.163681 & -0.11543 & -0.09913 & 0.83875 \\
\hline LOC_Os09g38920 & $\begin{array}{l}\text { thiol protease SEN102 precursor, } \\
\text { putative, expressed }\end{array}$ & 0.48973 & 0.344826 & 1.162962 & -0.06649 & 0.7911 & -0.5456 \\
\hline LOC_Os04g40090 & $\begin{array}{l}\text { zinc finger, } \mathrm{ZZ} \text { type family protein, } \\
\text { expressed }\end{array}$ & -0.498 & 0.257141 & 1.156063 & 0.125155 & -0.3272 & -0.23275 \\
\hline LOC_Os03g62670 & expressed protein & 0.110074 & 0.137405 & 1.150797 & -0.40509 & -5.19375 & \\
\hline LOC_Os08g41960 & $\begin{array}{l}\text { OsMADS37 - MADS-box family } \\
\text { gene with MIKC* type-box, } \\
\text { expressed }\end{array}$ & -0.29905 & 0.05266 & 1.150011 & -0.22538 & -0.4035 & \\
\hline LOC_Os01g48680 & $\begin{array}{l}\text { two pore calcium channel protein } 1 \text {, } \\
\text { putative, expressed }\end{array}$ & -0.55134 & -0.00607 & 1.149163 & 0.003772 & -1.02104 & 0.851 \\
\hline LOC_Os01g68270 & hypothetical protein & -0.07815 & -0.48779 & 1.147298 & & & \\
\hline LOC_Os03g49720 & $\begin{array}{l}\text { PAP fibrillin family domain } \\
\text { containing protein, expressed }\end{array}$ & -0.12428 & -0.25451 & 1.147003 & -0.51011 & -0.39348 & 1.4857 \\
\hline LOC_Os09g25150 & $\begin{array}{l}\text { cinnamoyl-CoA reductase, putative, } \\
\text { expressed }\end{array}$ & -0.07477 & 0.046599 & 1.139748 & -0.49846 & -2.8484 & 0.3165 \\
\hline LOC_Os03g63020 & $\begin{array}{l}\text { protein kinase domain containing } \\
\text { protein, expressed }\end{array}$ & -0.58531 & -0.68288 & 1.13762 & -0.36063 & 0.234188 & -0.0644 \\
\hline LOC_Os12g08060 & $\begin{array}{l}\text { universal stress protein family } \\
\text { protein, expressed }\end{array}$ & -0.03519 & 0.076099 & 1.137483 & & & \\
\hline LOC_Os02g46660 & $\begin{array}{l}\text { SNARE associated Golgi protein, } \\
\text { putative, expressed }\end{array}$ & -0.1782 & -0.27549 & 1.136795 & -0.64708 & -1.11264 & -0.08805 \\
\hline
\end{tabular}




\begin{tabular}{|c|c|c|c|c|c|c|c|}
\hline LOC_Os12g18650 & $\begin{array}{l}\text { Regulator of chromosome } \\
\text { condensation domain containing } \\
\text { protein, expressed }\end{array}$ & 0.007808 & -0.8847 & 1.135683 & -0.1154 & 0.293088 & 0.5959 \\
\hline LOC_Os06g12320 & $\begin{array}{l}\text { transmembrane amino acid } \\
\text { transporter protein, putative, } \\
\text { expressed }\end{array}$ & 0.206656 & -0.20898 & 1.130373 & -0.60465 & 1.984425 & 0.2901 \\
\hline LOC_Os04g08550 & $\begin{array}{l}\text { oxidoreductase, aldo/keto reductase } \\
\text { family protein, putative, expressed }\end{array}$ & -0.46204 & 0.244233 & 1.129256 & 1.254635 & 1.577375 & 0.81755 \\
\hline LOC_Os05g07090 & $\begin{array}{l}\text { acyl-coenzyme A dehydrogenase, } \\
\text { mitochondrial precursor, putative, } \\
\text { expressed }\end{array}$ & -0.24294 & -0.21336 & 1.127209 & 0.030344 & 0.794038 & 0.4984 \\
\hline LOC_Os02g51290 & HVA22, putative, expressed & -0.41325 & 0.112281 & 1.125723 & -0.43038 & 1.0189 & -0.45765 \\
\hline LOC_Os03g51030 & phytochrome A, putative, expressed & -0.58801 & -0.10434 & 1.123147 & -0.06637 & -0.16475 & -0.9871 \\
\hline LOC_Os08g06480 & $\begin{array}{l}\text { lissencephaly type-1-like homology } \\
\text { motif, putative, expressed }\end{array}$ & -0.28372 & 0.203639 & 1.120602 & 0.007266 & 0.279075 & 0.5318 \\
\hline LOC_Os05g48760 & $\begin{array}{l}\text { protein of unknown function } \\
\text { DUF1421 domain containing } \\
\text { protein, expressed }\end{array}$ & 0.066379 & 0.585729 & 1.119257 & 0.349112 & -0.22131 & \\
\hline LOC_Os07g 36800 & $\begin{array}{l}\text { UPF0041 domain containing } \\
\text { protein, putative, expressed }\end{array}$ & 0.41107 & -0.32729 & 1.117751 & 0.052251 & 0.02875 & 0.6103 \\
\hline LOC_Os08g04430 & expressed protein & 0.26873 & 0.214622 & 1.106868 & -0.1952 & -0.017 & 1.2635 \\
\hline LOC_Os09g20930 & expressed protein & -0.36991 & -0.02629 & 1.105611 & -0.15174 & 0.056138 & 0.0031 \\
\hline LOC_Os02g05330 & $\begin{array}{l}\text { DEAD-box ATP-dependent RNA } \\
\text { helicase, putative, expressed }\end{array}$ & -0.41632 & -0.1386 & 1.104676 & 0.150606 & 0.683875 & -0.0982 \\
\hline LOC_Os12g32980 & $\begin{array}{l}\text { potyvirus VPg interacting protein, } \\
\text { putative, expressed }\end{array}$ & -0.19729 & 0.051664 & 1.102846 & 0.165383 & 0.2045 & \\
\hline LOC_Os08g10500 & expressed protein & 0.320289 & -0.12027 & 1.102291 & 0.274456 & 0.3405 & 0.69805 \\
\hline LOC_Os09g 32820 & $\begin{array}{l}\text { uridine/cytidine kinase-like } 1 \text {, } \\
\text { putative, expressed }\end{array}$ & -0.51524 & -0.37 & 1.101382 & -0.03576 & -0.36338 & -0.4805 \\
\hline LOC_Os06g24190 & expressed protein & -0.20236 & -0.41818 & 1.099426 & 0.105074 & -0.22195 & 0.3046 \\
\hline LOC_Os11g04210 & $\begin{array}{l}\text { hydroxymethylglutaryl-CoA lyase, } \\
\text { putative, expressed }\end{array}$ & -0.15358 & 0.433137 & 1.098403 & -0.16084 & 0.445225 & \\
\hline LOC_Os02g28980 & $\begin{array}{l}\text { peptidyl-prolyl isomerase, putative, } \\
\text { expressed }\end{array}$ & -0.27476 & -0.11376 & 1.094579 & -0.19176 & -0.02863 & -0.3079 \\
\hline LOC_Os05g41460 & $\begin{array}{l}\text { cysteine proteinase inhibitor } \\
\text { precursor protein, putative, } \\
\text { expressed }\end{array}$ & -0.40899 & 0.31428 & 1.093339 & 0.113253 & -0.125 & 0.30685 \\
\hline LOC_Os12g12934 & $\begin{array}{l}\text { peptide transporter PTR3-A, } \\
\text { putative, expressed }\end{array}$ & -0.06925 & -0.38932 & 1.093157 & -0.43295 & -1.00473 & \\
\hline LOC_Os05g48660 & MRH1, putative, expressed & -0.20034 & -0.33807 & 1.092702 & -0.19292 & 0.9925 & \\
\hline LOC_Os03g 19250 & $\begin{array}{l}\text { AMP-binding enzyme, putative, } \\
\text { expressed }\end{array}$ & -0.16074 & -0.22461 & 1.091017 & -0.06423 & 1.109375 & -0.0536 \\
\hline LOC_Os03g30950 & $\begin{array}{l}\text { acyl-desaturase, chloroplast } \\
\text { precursor, putative, expressed }\end{array}$ & -0.11192 & 0.136272 & 1.090354 & -0.17436 & -0.1047 & 0.17145 \\
\hline LOC_Os09g38080 & $\begin{array}{l}\text { retrotransposon protein, putative, } \\
\text { unclassified, expressed }\end{array}$ & 0.261327 & -0.29016 & 1.088508 & -0.29391 & 0.859913 & 0.32025 \\
\hline LOC_Os11g02100 & $\begin{array}{l}\text { peroxidase precursor, putative, } \\
\text { expressed }\end{array}$ & -0.54112 & -0.36393 & 1.086922 & 0.062408 & -0.31075 & -0.3057 \\
\hline LOC_Os04g42420 & nodulin, putative, expressed & -0.15788 & 0.01602 & 1.085176 & 0.51516 & -0.03775 & -0.45615 \\
\hline LOC_Os11g14180 & expressed protein & -0.55127 & 0.548044 & 1.082046 & -0.11956 & -0.4745 & 0.25215 \\
\hline LOC_Os03g51000 & $\begin{array}{l}\text { 3,4-dihydroxy-2-butanone kinase, } \\
\text { putative, expressed }\end{array}$ & -0.52282 & -0.17063 & 1.081765 & -0.33823 & -0.25858 & 0.1209 \\
\hline LOC_Os03g14570 & expressed protein & 0.088861 & 0.344485 & 1.081324 & 0.204319 & -1.45838 & \\
\hline LOC_Os01g22510 & $\begin{array}{l}\text { cyclase/dehydrase family protein, } \\
\text { expressed }\end{array}$ & -0.32732 & -0.24986 & 1.078861 & -0.09353 & 0.4653 & \\
\hline LOC_Os05g02420 & expressed protein & 0.119834 & -0.22646 & 1.075074 & 0.164037 & -1.1541 & 0.42975 \\
\hline
\end{tabular}




\begin{tabular}{|c|c|c|c|c|c|c|c|}
\hline LOC_Os05g07030 & $\begin{array}{l}\text { arginyl-tRNA synthetase, putative, } \\
\text { expressed }\end{array}$ & -0.24674 & -0.30547 & 1.074287 & 0.109058 & -0.0095 & -0.2099 \\
\hline LOC_Os10g05130 & expressed protein & -0.25923 & -0.59408 & 1.071806 & -0.16853 & 0.127625 & \\
\hline LOC_Os05g01570 & $\begin{array}{l}\text { auxin-induced protein } 5 \mathrm{NG} 4 \text {, } \\
\text { putative, expressed }\end{array}$ & -0.54067 & -0.60173 & 1.07162 & -0.50998 & 0.7339 & \\
\hline LOC_Os04g35590 & $\begin{array}{l}\text { thioesterase family protein, putative, } \\
\text { expressed }\end{array}$ & -0.43749 & -0.15268 & 1.070574 & 0.086598 & 0.069625 & -0.0041 \\
\hline LOC_Os03g14160 & hypothetical protein & 0.100735 & -0.02458 & 1.070315 & & & \\
\hline LOC_Os01g43030 & $\begin{array}{l}\text { tetratricopeptide repeat domain } \\
\text { containing protein, expressed }\end{array}$ & -0.42843 & -0.29044 & 1.070132 & 0.074843 & -0.08275 & \\
\hline LOC_Os06g05100 & transketolase, putative, expressed & -0.54191 & -0.47143 & 1.06697 & -0.15485 & -0.2606 & -0.6091 \\
\hline LOC_Os05g40420 & $\begin{array}{l}\text { 2,3-bisphosphoglycerate-independe } \\
\text { nt phosphoglycerate mutase, } \\
\text { putative, expressed }\end{array}$ & -0.27958 & 0.015546 & 1.06462 & -0.06929 & 0.1365 & -0.2629 \\
\hline LOC_Os09g28740 & $\begin{array}{l}\text { gibberellin receptor GID1L2, } \\
\text { putative, expressed }\end{array}$ & -0.10773 & -0.58761 & 1.063714 & -0.54699 & -0.808 & -0.55515 \\
\hline LOC_Os11g40540 & $\begin{array}{l}\text { transporter family protein, putative, } \\
\text { expressed }\end{array}$ & 0.018132 & -0.26863 & 1.062409 & -0.19457 & -0.25071 & 0.25945 \\
\hline LOC_Os01g72480 & $\begin{array}{l}\text { zinc finger, } \mathrm{C} 3 \mathrm{HC} 4 \text { type domain } \\
\text { containing protein, expressed }\end{array}$ & -0.50383 & -0.35123 & 1.062257 & -0.30968 & 0.219638 & 0.4181 \\
\hline LOC_Os08g42040 & $\begin{array}{l}\text { LTPL80 - Protease inhibitor/seed } \\
\text { storage/LTP family protein } \\
\text { precursor, expressed }\end{array}$ & 0.054544 & -0.47588 & 1.062106 & -0.25953 & 0.0192 & -0.22515 \\
\hline LOC_Os10g36650 & actin, putative, expressed & -0.1588 & -0.02492 & 1.060544 & -0.44769 & -0.00863 & -0.45965 \\
\hline LOC_Os01g69030 & $\begin{array}{l}\text { sucrose-phosphate synthase, } \\
\text { putative, expressed }\end{array}$ & 0.079348 & 0.128285 & 1.056808 & -0.42691 & -0.80596 & \\
\hline LOC_Os09g28910 & $\begin{array}{l}\text { carbonic anhydrase, chloroplast } \\
\text { precursor, putative, expressed }\end{array}$ & -0.24202 & -0.07622 & 1.054319 & 0.404322 & 1.04325 & 0.25025 \\
\hline LOC_Os04g49350 & $\begin{array}{l}\text { PPR repeat domain containing } \\
\text { protein, putative, expressed }\end{array}$ & -0.21721 & 0.40794 & 1.053956 & & & 0.01315 \\
\hline LOC_Os03g60850 & $\begin{array}{l}\text { peptide transporter PTR2, putative, } \\
\text { expressed }\end{array}$ & -0.40765 & -0.09754 & 1.053886 & 0.058761 & -0.27748 & 0.2621 \\
\hline LOC_Os03g22800 & $\begin{array}{l}\text { OsFBT5 - F-box and tubby domain } \\
\text { containing protein, expressed }\end{array}$ & -0.14899 & -0.03947 & 1.051548 & 0.026613 & 0.862863 & -0.1252 \\
\hline LOC_Os03g58580 & nodulin, putative, expressed & -0.22586 & -0.21003 & 1.051069 & 0.229347 & -0.25113 & 0.63175 \\
\hline LOC_Os12g38150 & osmotin, putative, expressed & -0.0697 & -0.22 & 1.049965 & -0.83868 & 2.205188 & \\
\hline LOC_Os01g06660 & $\begin{array}{l}\text { thiamine pyrophosphate enzyme, } \\
\text { C-terminal TPP binding domain } \\
\text { containing protein, expressed }\end{array}$ & -0.13967 & 0.52488 & 1.049452 & 0.762345 & 1.1188 & 0.64255 \\
\hline LOC_Os11g05810 & expressed protein & -0.42933 & -0.36326 & 1.047226 & 0.585963 & 0.40125 & 0.26725 \\
\hline LOC_Os02g47800 & $\begin{array}{l}\text { monodehydroascorbate reductase, } \\
\text { putative, expressed }\end{array}$ & -0.34908 & -0.71376 & 1.046721 & -0.12916 & -1.038 & 0.62625 \\
\hline LOC_Os12g39660 & $\begin{array}{l}\text { calcium-transporting ATPase, } \\
\text { plasma membrane-type, putative, } \\
\text { expressed }\end{array}$ & -0.31604 & -0.02244 & 1.045158 & 0.123435 & 0.315125 & 0.04975 \\
\hline LOC_Os09g25710 & $\begin{array}{l}\text { keratin, type I cytoskeletal 9, } \\
\text { putative, expressed }\end{array}$ & 0.191817 & 0.130082 & 1.043402 & -0.2112 & -1.20523 & \\
\hline LOC_Os03g50480 & $\begin{array}{l}\text { phosphoglucomutase, putative, } \\
\text { expressed }\end{array}$ & -0.33013 & -0.10303 & 1.042341 & -0.45637 & -0.59638 & -0.2779 \\
\hline LOC_Os06g48750 & $\begin{array}{l}\text { DEAD-box ATP-dependent RNA } \\
\text { helicase, putative, expressed }\end{array}$ & -0.56423 & -0.4224 & 1.036989 & 0.12172 & -0.146 & -0.16555 \\
\hline LOC_Os02g52860 & $\begin{array}{l}\text { phosphate carrier protein, } \\
\text { mitochondrial precursor, putative, } \\
\text { expressed }\end{array}$ & -0.44223 & 0.389755 & 1.035635 & 0.108075 & 0.736 & 0.1836 \\
\hline LOC_Os01g72100 & $\begin{array}{l}\text { OsCML10 - Calmodulin-related } \\
\text { calcium sensor protein, expressed }\end{array}$ & 0.006688 & 0.369373 & 1.032705 & -0.19663 & -0.24963 & -0.41665 \\
\hline
\end{tabular}




\begin{tabular}{|c|c|c|c|c|c|c|c|}
\hline LOC_Os01g48420 & peroxiredoxin, putative, expressed & -0.22509 & -0.02932 & 1.031877 & -0.12011 & -0.08275 & -0.22195 \\
\hline LOC_Os02g53320 & $\begin{array}{l}\text { universal stress protein domain } \\
\text { containing protein, putative, } \\
\text { expressed }\end{array}$ & -0.05634 & 0.073099 & 1.031667 & -0.42087 & -0.00179 & 0.61115 \\
\hline LOC_Os05g09440 & $\begin{array}{l}\text { NADP-dependent malic enzyme, } \\
\text { chloroplast precursor, putative, } \\
\text { expressed }\end{array}$ & -0.53193 & 0.189053 & 1.031565 & -0.65779 & -0.1106 & 2.34375 \\
\hline LOC_Os04g12530 & $\begin{array}{l}\text { amino acid transporter family } \\
\text { protein, putative, expressed }\end{array}$ & -0.15149 & -0.14904 & 1.030677 & & & \\
\hline LOC_Os09g14670 & $\begin{array}{l}\text { phosphoenolpyruvate carboxylase, } \\
\text { putative, expressed }\end{array}$ & -0.54232 & -0.06101 & 1.02944 & -0.72492 & -0.0785 & \\
\hline LOC_Os05g39250 & $\begin{array}{l}\text { phosphatidylethanolamine-binding } \\
\text { protein, putative, expressed }\end{array}$ & -0.06532 & 0.241144 & 1.02797 & 0.345626 & 0.752175 & \\
\hline LOC_Os10g22050 & expressed protein & 0.577465 & -0.78696 & 1.027306 & -0.2366 & 1.03845 & \\
\hline LOC_Os03g09110 & $\begin{array}{l}\text { mitochondrial carrier protein, } \\
\text { putative, expressed }\end{array}$ & -0.49234 & -0.17141 & 1.025791 & 0.163494 & -0.12014 & \\
\hline LOC_Os03g43010 & expressed protein & -0.58527 & -0.9586 & 1.024259 & 0.083629 & -0.29059 & -1.0102 \\
\hline LOC_Os03g08900 & $\begin{array}{l}\text { MATE efflux family protein, } \\
\text { putative, expressed }\end{array}$ & -0.12457 & 0.032906 & 1.024011 & 1.276876 & 1.4326 & \\
\hline LOC_Os12g39320 & $\begin{array}{l}\text { DUF221 domain containing protein, } \\
\text { expressed }\end{array}$ & -0.55327 & 0.142651 & 1.023979 & 0.125373 & 0.3887 & 0.0673 \\
\hline LOC_Os03g53910 & $\begin{array}{l}\text { tetratricopeptide repeat domain } \\
\text { containing protein, expressed }\end{array}$ & 0.040796 & 0.091853 & 1.022612 & -0.35569 & -0.976 & -0.77135 \\
\hline LOC_Os07g49150 & $\begin{array}{l}26 \mathrm{~S} \text { protease regulatory subunit } 4 \text {, } \\
\text { putative, expressed }\end{array}$ & -0.43265 & 0.117105 & 1.021848 & 0.13891 & 0.30025 & 0.00385 \\
\hline LOC_Os03g57790 & $\begin{array}{l}\text { ubiquitin-conjugating enzyme, } \\
\text { putative, expressed }\end{array}$ & -0.40841 & -0.1756 & 1.021733 & -0.11332 & -0.55425 & \\
\hline LOC_Os03g64080 & $\begin{array}{l}\text { retrotransposon protein, putative, } \\
\text { Ty1-copia subclass, expressed }\end{array}$ & -0.53751 & 0.076514 & 1.020101 & -0.04934 & -0.09113 & \\
\hline LOC_Os04g39300 & $\begin{array}{l}\text { heavy metal transport/detoxification } \\
\text { protein, putative, expressed }\end{array}$ & 0.180227 & 0.580248 & 1.019349 & & & \\
\hline LOC_Os03g53190 & $\begin{array}{l}\text { Core histone } \mathrm{H} 2 \mathrm{~A} / \mathrm{H} 2 \mathrm{~B} / \mathrm{H} 3 / \mathrm{H} 4 \\
\text { domain containing protein, putative, } \\
\text { expressed }\end{array}$ & -0.3335 & -0.2775 & 1.017954 & 0.082156 & 0.80555 & \\
\hline LOC_Os09g27210 & $\begin{array}{l}\text { lecithine cholesterol acyltransferase, } \\
\text { putative, expressed }\end{array}$ & -0.39944 & -0.38428 & 1.017228 & $6.00 \mathrm{E}-04$ & -1.00868 & -0.0873 \\
\hline LOC_Os03g29240 & PDI, putative, expressed & 0.293096 & 0.250577 & 1.014347 & 0.236438 & 1.354875 & \\
\hline LOC_Os03g16670 & $\begin{array}{l}\text { haloacid dehalogenase-like } \\
\text { hydrolase family protein, putative, } \\
\text { expressed }\end{array}$ & -0.27331 & 0.451622 & 1.012712 & -1.27 & 0.8325 & 0.2639 \\
\hline LOC_Os07g47110 & $\begin{array}{l}\text { OsFBT11 - F-box and tubby domain } \\
\text { containing protein, expressed }\end{array}$ & -0.15422 & -0.33492 & 1.012662 & -0.15939 & 0.504 & 0.3903 \\
\hline LOC_Os10g11310 & expressed protein & -0.21577 & -0.12126 & 1.012405 & -0.90308 & -0.32756 & 0.2846 \\
\hline LOC_Os06g5 51150 & $\begin{array}{l}\text { catalase isozyme B, putative, } \\
\text { expressed }\end{array}$ & 0.104165 & -0.0047 & 1.01136 & -0.18283 & 1.9255 & 0.1393 \\
\hline LOC_Os04g40910 & $\begin{array}{l}\text { OsFBX146 - F-box domain } \\
\text { containing protein, expressed }\end{array}$ & -0.30441 & -0.247 & 1.011335 & 0.034055 & 0.296163 & -0.2837 \\
\hline LOC_Os05g06690 & $\begin{array}{l}\text { HECT-domain domain containing } \\
\text { protein, expressed }\end{array}$ & -0.26418 & 0.26078 & 1.010832 & -0.09234 & 0.067375 & 0.04175 \\
\hline LOC_Os03g09220 & $\begin{array}{l}\text { stage II sporulation protein E, } \\
\text { putative, expressed }\end{array}$ & 0.254703 & -0.12094 & 1.010014 & -0.08671 & -0.79063 & 0.33465 \\
\hline LOC_Os08g12120 & $\begin{array}{l}\text { retrotransposon protein, putative, } \\
\text { unclassified, expressed }\end{array}$ & 0.084349 & -0.39533 & 1.006446 & & & \\
\hline LOC_Os $05 \mathrm{~g} 44360$ & $\begin{array}{l}\text { oligosaccharyl transferase, putative, } \\
\text { expressed }\end{array}$ & -0.15719 & -0.67189 & 1.004314 & 0.111088 & 0.131625 & -0.1905 \\
\hline
\end{tabular}




\begin{tabular}{|c|c|c|c|c|c|c|c|}
\hline LOC_Os03g39000 & $\begin{array}{l}\text { inositol-1-monophosphatase, } \\
\text { putative, expressed }\end{array}$ & -0.14858 & 0.06116 & 1.00401 & -0.46813 & 0.453425 & -0.20775 \\
\hline LOC_Os03g22690 & $\begin{array}{l}\text { nucleoporin interacting component, } \\
\text { putative, expressed }\end{array}$ & -0.50319 & 0.130692 & 1.003887 & 0.084782 & -0.01069 & -0.39085 \\
\hline LOC_Os08g34700 & GDU1, putative, expressed & -0.10001 & -0.01659 & 1.001906 & -0.84406 & -1.76784 & \\
\hline LOC_Os06g25439 & $\begin{array}{l}\text { NAD dependent } \\
\text { epimerase/dehydratase family } \\
\text { protein, putative, expressed }\end{array}$ & -0.38199 & -0.02434 & 1.000954 & -0.12921 & -1.28958 & 0.41145 \\
\hline LOC_Os01g73170 & $\begin{array}{l}\text { peroxidase precursor, putative, } \\
\text { expressed }\end{array}$ & -0.14406 & 0.132066 & 0.999368 & 0.621027 & 1.945875 & \\
\hline LOC_Os01g03730 & nuclease PA3, putative, expressed & -0.32053 & 0.450476 & 0.996529 & -0.10037 & 1.344213 & 0.37935 \\
\hline LOC_Os07g43950 & $\begin{array}{l}\text { RNA recognition motif containing } \\
\text { protein, putative, expressed }\end{array}$ & -0.11806 & -0.0796 & 0.993747 & -0.36902 & 0.380138 & 0.0013 \\
\hline LOC_Os08g10080 & $\begin{array}{l}\text { no apical meristem protein, putative, } \\
\text { expressed }\end{array}$ & 0.181963 & 0.389629 & 0.990803 & -0.60271 & 2.041238 & 0.96545 \\
\hline LOC_Os05g38530 & $\begin{array}{l}\text { DnaK family protein, putative, } \\
\text { expressed }\end{array}$ & 0.618571 & -0.04209 & 0.98978 & -0.20952 & -0.64549 & \\
\hline LOC_Os01g07170 & $\begin{array}{l}\text { HORMA domain containing } \\
\text { protein, putative, expressed }\end{array}$ & 0.490974 & -0.04741 & 0.989615 & -0.14852 & 0.008825 & \\
\hline LOC_Os10g42730 & expressed protein & -0.33884 & 0.151668 & 0.989363 & & & -0.4344 \\
\hline LOC_Os04g42430 & $\begin{array}{l}\text { EF hand family protein, putative, } \\
\text { expressed }\end{array}$ & -0.29251 & 0.06572 & 0.988155 & 0.26279 & 0.042 & 0.0947 \\
\hline LOC_Os06g07780 & $\begin{array}{l}\text { vesicle-associated membrane } \\
\text { protein, putative, expressed }\end{array}$ & -0.21536 & -0.24507 & 0.98809 & 0.095614 & -0.3425 & -0.07455 \\
\hline LOC_Os09g23660 & ZIM motif family protein, expressed & 0.027808 & -0.02236 & 0.987433 & 0.847961 & 0.267988 & 0.69895 \\
\hline LOC_Os12g38850 & $\begin{array}{l}\text { DUF1336 domain containing } \\
\text { protein, expressed }\end{array}$ & 0.044845 & 0.126746 & 0.984692 & 0.106978 & -1.15936 & -0.4629 \\
\hline LOC_Os03g18690 & $\begin{array}{l}26 \mathrm{~S} \text { protease regulatory subunit } 4 \text {, } \\
\text { putative, expressed }\end{array}$ & -0.58587 & 0.060749 & 0.983933 & -0.01071 & -0.14275 & -0.3428 \\
\hline LOC_Os06g49990 & $\begin{array}{l}\text { UPF0183 protein, putative, } \\
\text { expressed }\end{array}$ & -0.55074 & -0.62192 & 0.971985 & 0.022064 & 0.70105 & 0.40735 \\
\hline LOC_Os11g11100 & $\begin{array}{l}\text { bZIP transcription factor domain } \\
\text { containing protein, expressed }\end{array}$ & -0.20968 & 0.366779 & 0.970571 & -0.24061 & -0.008 & 0.0924 \\
\hline LOC_Os04g41460 & $\begin{array}{l}\text { transporter family protein, putative, } \\
\text { expressed }\end{array}$ & -0.13945 & 0.079014 & 0.968329 & 0.316185 & 0.820313 & 0.10985 \\
\hline LOC_Os03g53750 & $\begin{array}{l}\text { nuclear prelamin A recognition } \\
\text { factor, putative, expressed }\end{array}$ & 0.219473 & 0.050967 & 0.967272 & 0.326895 & 0.629775 & -0.00635 \\
\hline LOC_Os04g10680 & $\begin{array}{l}\text { zinc finger, } \mathrm{C} 3 \mathrm{HC} 4 \text { type domain } \\
\text { containing protein, expressed }\end{array}$ & -0.59401 & 0.153401 & 0.965815 & 0.039396 & 0.066125 & 0.34315 \\
\hline LOC_Os06g01390 & $\begin{array}{l}\text { acyl-coenzyme A oxidase 1.2, } \\
\text { peroxisomal, putative, expressed }\end{array}$ & -0.38116 & -0.25495 & 0.960934 & 0.027744 & 1.319625 & 0.1414 \\
\hline LOC_Os10g38710 & $\begin{array}{l}\text { glutathione S-transferase, putative, } \\
\text { expressed }\end{array}$ & -0.47756 & -0.71346 & 0.958159 & -0.179 & -4.60589 & \\
\hline LOC_Os05g33880 & $\begin{array}{l}\text { cysteine proteinase inhibitor } \\
\text { precursor protein, putative, } \\
\text { expressed }\end{array}$ & 0.038099 & -0.32454 & 0.957805 & -0.06224 & 0.178875 & 0.0182 \\
\hline LOC_Os03g32580 & $\begin{array}{l}\text { BRASSINOSTEROID } \\
\text { INSENSITIVE 1-associated } \\
\text { receptor kinase } 1 \text { precursor, } \\
\text { putative, expressed }\end{array}$ & -0.57558 & 0.447174 & 0.956571 & 1.061583 & 0.790338 & 0.8929 \\
\hline LOC_Os01g14630 & $\begin{array}{l}\text { polyprenyl synthetase, putative, } \\
\text { expressed }\end{array}$ & -0.00893 & -0.26621 & 0.954226 & & & \\
\hline LOC_Os04g34230 & $\begin{array}{l}\text { RING-H2 finger protein, putative, } \\
\text { expressed }\end{array}$ & 0.636271 & -0.25669 & 0.953731 & -0.50699 & -0.03531 & \\
\hline LOC_Os10g26620 & $\begin{array}{l}\text { dof zinc finger domain containing } \\
\text { protein, putative, expressed }\end{array}$ & 0.075263 & -0.40047 & 0.953127 & -0.62638 & 0.328488 & 0.3899 \\
\hline
\end{tabular}




\begin{tabular}{|c|c|c|c|c|c|c|c|}
\hline LOC_Os03g10500 & $\begin{array}{l}\text { adenylyl-sulfate kinase, putative, } \\
\text { expressed }\end{array}$ & -0.04053 & 0.195067 & 0.953105 & & & \\
\hline LOC_Os08g28670 & $\begin{array}{l}\text { pathogenesis-related Bet v I family } \\
\text { protein, putative, expressed }\end{array}$ & 0.508105 & -0.49746 & 0.953034 & -0.94187 & -1.13256 & -0.2104 \\
\hline LOC_Os07g08710 & $\begin{array}{l}\text { AT hook-containing DNA-binding } \\
\text { protein, putative, expressed }\end{array}$ & -0.12135 & 0.145286 & 0.95296 & -0.13783 & -0.882 & -0.08055 \\
\hline LOC_Os02g02980 & $\begin{array}{l}\text { MATE domain containing protein, } \\
\text { expressed }\end{array}$ & -0.27363 & -0.32832 & 0.952817 & -0.01301 & 0.500888 & \\
\hline LOC_Os06g 10520 & $\begin{array}{l}\text { pantothenate kinase, putative, } \\
\text { expressed }\end{array}$ & -0.39789 & -0.02842 & 0.952438 & 1.122785 & 2.181963 & 0.7178 \\
\hline LOC_Os01g33784 & $\begin{array}{l}\text { lipase family protein, putative, } \\
\text { expressed }\end{array}$ & -0.26582 & 0.129191 & 0.951342 & -0.1599 & 0.195988 & 0.56145 \\
\hline LOC_Os07g47510 & $\begin{array}{l}\text { stress-related protein, putative, } \\
\text { expressed }\end{array}$ & -0.19998 & -0.31335 & 0.950471 & -0.30777 & -0.67575 & -0.72635 \\
\hline LOC_Os08g32870 & $\begin{array}{l}\text { aldehyde dehydrogenase, putative, } \\
\text { expressed }\end{array}$ & -0.34967 & -0.44655 & 0.949209 & -0.13667 & 0.45675 & -0.0291 \\
\hline LOC_Os05g51480 & $\begin{array}{l}\text { cleavage and polyadenylation } \\
\text { specificity factor, putative, } \\
\text { expressed }\end{array}$ & -0.50767 & 0.538376 & 0.94136 & 0.041876 & -0.00175 & -0.2642 \\
\hline LOC_Os10g28360 & $\begin{array}{l}\text { 1,2-dihydroxy-3-keto-5-methylthiop } \\
\text { entene dioxygenase protein, } \\
\text { putative, expressed }\end{array}$ & -0.23444 & -0.42388 & 0.940983 & -0.83293 & -0.42488 & 0.48755 \\
\hline LOC_Os03g31170 & $\begin{array}{l}\text { inosine-uridine preferring } \\
\text { nucleoside hydrolase family protein, } \\
\text { putative, expressed }\end{array}$ & -0.41041 & -0.6169 & 0.936446 & -0.10343 & -0.06238 & 0.06215 \\
\hline LOC_Os03g37470 & $\begin{array}{l}\text { MATE efflux family protein, } \\
\text { putative, expressed }\end{array}$ & -0.42537 & 0.047182 & 0.935713 & -0.47235 & -0.70395 & -0.31705 \\
\hline LOC_Os03g40100 & $\begin{array}{l}\text { ACT domain containing protein, } \\
\text { expressed }\end{array}$ & -0.04836 & 0.597238 & 0.93264 & 0.697239 & -0.64331 & -0.0025 \\
\hline LOC_Os03g 15000 & $\begin{array}{l}\text { Zinc finger, } \mathrm{C} 3 \mathrm{HC} 4 \text { type domain } \\
\text { containing protein, expressed }\end{array}$ & -0.16019 & -0.10785 & 0.931465 & 0.067046 & 0.3025 & 0.3585 \\
\hline LOC_Os06g 11310 & $\begin{array}{l}\text { plastocyanin-like domain containing } \\
\text { protein, putative, expressed }\end{array}$ & 0.181089 & 0.125639 & 0.930544 & -1.48508 & -1.31138 & 0.2308 \\
\hline LOC_Os02g11640 & $\begin{array}{l}\text { UDP-glucoronosyl and } \\
\text { UDP-glucosyl transferase, putative, } \\
\text { expressed }\end{array}$ & 0.105678 & 0.017209 & 0.926131 & -0.42564 & -0.42626 & \\
\hline LOC_Os06g05130 & $\begin{array}{l}\text { myristoyl-acyl carrier protein } \\
\text { thioesterase, chloroplast precursor, } \\
\text { putative, expressed }\end{array}$ & -0.23713 & 0.463926 & 0.925612 & 0.039041 & 0.2511 & 2.42285 \\
\hline LOC_Os08g09690 & $\begin{array}{l}\text { nuclear transcription factor Y } \\
\text { subunit, putative, expressed }\end{array}$ & -0.05626 & 0.099756 & 0.924744 & -0.61638 & -0.56145 & -0.2188 \\
\hline LOC_Os04g56160 & $\begin{array}{l}\text { plasma membrane ATPase, } \\
\text { putative, expressed }\end{array}$ & -0.45533 & -0.03629 & 0.924593 & 0.047113 & 0.173875 & 0.2996 \\
\hline LOC_Os01g66720 & $\begin{array}{l}\text { NADP-dependent oxidoreductase, } \\
\text { putative, expressed }\end{array}$ & -0.12324 & -0.28079 & 0.924044 & -0.09884 & -0.34989 & -0.24285 \\
\hline LOC_Os04g57870 & expressed protein & 0.039956 & 0.258814 & 0.923658 & -0.01474 & \#\#\#\#\#\#\# & -0.2498 \\
\hline LOC_Os01g53880 & $\begin{array}{l}\text { OsIAA6 - Auxin-responsive } \\
\text { Aux/IAA gene family member, } \\
\text { expressed }\end{array}$ & 0.264048 & -0.51953 & 0.921864 & 0.335769 & 0.42325 & 0.1149 \\
\hline LOC_Os04g39190 & $\begin{array}{l}\text { cell division protease } \mathrm{ftsH} \text { homolog } \\
\text { 4, putative, expressed }\end{array}$ & -0.48118 & -0.49971 & 0.919882 & -0.05561 & 0.026188 & \\
\hline LOC_Os07g36190 & $\begin{array}{l}\text { hydrolase, NUDIX family, domain } \\
\text { containing protein, expressed }\end{array}$ & 0.347625 & 0.250483 & 0.917119 & -0.24771 & -1.88038 & -0.3294 \\
\hline LOC_Os06g22060 & $\begin{array}{l}\text { pyrophosphate--fructose } \\
\text { 6-phosphate 1-phosphotransferase } \\
\text { subunit alpha, putative, expressed }\end{array}$ & -0.05982 & -0.23702 & 0.916024 & -0.07601 & -1.28843 & -0.66225 \\
\hline
\end{tabular}




\begin{tabular}{|c|c|c|c|c|c|c|c|}
\hline LOC_Os08g27010 & APE1, putative, expressed & -0.55259 & -0.5823 & 0.91329 & -0.17276 & -2.31463 & 0.17095 \\
\hline LOC_Os05g38550 & $\begin{array}{l}\text { ubiquitin-conjugating enzyme, } \\
\text { putative, expressed }\end{array}$ & -0.45461 & -0.20611 & 0.912858 & 0.011173 & -0.21763 & \\
\hline LOC_Os06g02420 & ATOZI1, putative, expressed & 0.168433 & -0.42336 & 0.910915 & -0.40661 & -1.8432 & -0.81195 \\
\hline LOC_Os09g38130 & $\begin{array}{l}\text { auxin efflux carrier component, } \\
\text { putative, expressed }\end{array}$ & 0.402758 & 0.51029 & 0.909661 & 0.318828 & 1.52 & 0.1604 \\
\hline LOC_Os04g56620 & $\begin{array}{l}\text { molybdopterin biosynthesis protein } \\
\text { CNX1, putative, expressed }\end{array}$ & -0.35423 & 0.02123 & 0.909087 & & & \\
\hline LOC_Os03g27010 & expressed protein & -0.05657 & 0.280987 & 0.908628 & -0.0967 & 1.071625 & -0.22905 \\
\hline LOC_Os08g09200 & $\begin{array}{l}\text { aconitate hydratase protein, } \\
\text { putative, expressed }\end{array}$ & -0.45228 & 0.279104 & 0.908333 & -0.06238 & 2.100625 & 0.15155 \\
\hline LOC_Os11g37730 & $\begin{array}{l}\text { glutathione S-transferase, } \\
\text { N-terminal domain containing } \\
\text { protein, expressed }\end{array}$ & -0.35628 & -0.344 & 0.906745 & 0.272657 & 1.43675 & 0.9467 \\
\hline LOC_Os06g39690 & $\begin{array}{l}\text { SOUL heme-binding protein, } \\
\text { putative, expressed }\end{array}$ & -0.32928 & -0.27064 & 0.90282 & -0.17921 & -0.73008 & -0.63805 \\
\hline LOC_Os08g16930 & expressed protein & -0.39588 & -0.51175 & 0.902631 & 0.044066 & 0.327 & 0.78295 \\
\hline LOC_Os06g23530 & $\begin{array}{l}\text { pre-mRNA-splicing factor } \\
\text { ATP-dependent RNA helicase, } \\
\text { putative, expressed }\end{array}$ & -0.52396 & -0.32974 & 0.901173 & -0.12048 & -0.1842 & 0.00525 \\
\hline LOC_Os03g20900 & $\begin{array}{l}\text { Myb transcription factor, putative, } \\
\text { expressed }\end{array}$ & -0.18326 & -0.03901 & 0.896889 & -0.4615 & -0.0525 & -0.1282 \\
\hline LOC_Os07g43700 & $\begin{array}{l}\text { lactate/malate dehydrogenase, } \\
\text { putative, expressed }\end{array}$ & 0.085509 & -0.20581 & 0.892387 & -1.01888 & -2.05089 & $1.00 \mathrm{E}-04$ \\
\hline LOC_Os10g35250 & $\begin{array}{l}\text { vacuolar protein-sorting protein } \\
\text { bro1, putative, expressed }\end{array}$ & 0.21204 & -0.11224 & 0.890238 & 0.101033 & 0.34025 & 0.2251 \\
\hline LOC_Os02g03840 & expressed protein & 0.157645 & 0.057189 & 0.887944 & -0.08485 & 0.228375 & 0.0866 \\
\hline LOC_Os03g62660 & $\begin{array}{l}\text { transposon protein, putative, } \\
\text { unclassified, expressed }\end{array}$ & -0.43332 & 0.038827 & 0.886737 & -0.00603 & 0.17365 & -0.0078 \\
\hline LOC_Os07g10150 & $\begin{array}{l}\text { coatomer subunit gamma-2, } \\
\text { putative, expressed }\end{array}$ & -0.49127 & 0.254893 & 0.886018 & 0.034845 & 0.72725 & 0.28335 \\
\hline LOC_Os09g26670 & expressed protein & -0.09807 & -0.39363 & 0.885966 & -2.61947 & -1.84009 & 0.169 \\
\hline LOC_Os02g18450 & $\begin{array}{l}\text { GTP-binding protein typA/bipA, } \\
\text { putative, expressed }\end{array}$ & -0.35267 & 0.078962 & 0.885346 & -0.24902 & -2.55079 & -0.5319 \\
\hline LOC_Os05g01090 & pex14, putative, expressed & -0.45647 & -0.14013 & 0.883355 & 0.233186 & 0.1025 & 0.3559 \\
\hline LOC_Os01g31360 & expressed protein & -0.13371 & 0.310415 & 0.881878 & -0.53127 & 0.85225 & -0.32245 \\
\hline LOC_Os01g17390 & $\begin{array}{l}\text { OsFBX5 - F-box domain containing } \\
\text { protein, expressed }\end{array}$ & 0.036931 & 0.065427 & 0.881167 & -0.00263 & -0.93379 & -0.0278 \\
\hline LOC_Os04g45070 & remorin, putative, expressed & -0.31149 & -0.48699 & 0.878158 & -0.14335 & -1.08863 & -0.37375 \\
\hline LOC_Os07g10460 & $\begin{array}{l}\text { 5-nucleotidase surE, putative, } \\
\text { expressed }\end{array}$ & -0.35841 & -0.02737 & 0.877157 & -0.10429 & 0.611063 & 0.12145 \\
\hline LOC_Os02g20310 & expressed protein & -0.24624 & -0.48923 & 0.876941 & 0.033403 & -0.42238 & 0.0791 \\
\hline LOC_Os10g07440 & expressed protein & 0.125591 & -0.09947 & 0.875301 & -0.27255 & 0.091375 & 0.42775 \\
\hline LOC_Os04g43800 & $\begin{array}{l}\text { phenylalanine ammonia-lyase, } \\
\text { putative, expressed }\end{array}$ & -0.22079 & 0.173247 & 0.874567 & 3.276763 & -1.99279 & 2.9547 \\
\hline LOC_Os03g19580 & expressed protein & -0.16672 & 0.299404 & 0.873189 & 0.487985 & 1.694875 & 1.13015 \\
\hline LOC_Os04g40040 & $\begin{array}{l}\text { copper methylamine oxidase } \\
\text { precursor, putative, expressed }\end{array}$ & 0.08753 & -0.39684 & 0.867393 & 0.475336 & 0.277 & -1.19655 \\
\hline LOC_Os01g71240 & $\begin{array}{l}\text { calcium-transporting ATPase, } \\
\text { plasma membrane-type, putative, } \\
\text { expressed }\end{array}$ & -0.32338 & -0.18442 & 0.867241 & 0.07072 & -0.0215 & 0.70065 \\
\hline LOC_Os05g01760 & $\begin{array}{l}\text { lysine ketoglutarate reductase } \\
\text { trans-splicing related } 1 \text {, putative, } \\
\text { expressed }\end{array}$ & 0.11533 & -0.32697 & 0.866619 & -0.43484 & 0.829 & 0.37055 \\
\hline LOC_Os07g44610 & $\begin{array}{l}\text { pyrrolidone-carboxylate peptidase, } \\
\text { putative, expressed }\end{array}$ & -0.09326 & -0.26084 & 0.864527 & 0.066857 & 0.86925 & -0.31845 \\
\hline
\end{tabular}




\begin{tabular}{|c|c|c|c|c|c|c|c|}
\hline LOC_Os08g07960 & $\begin{array}{l}\text { mitotic checkpoint protein, putative, } \\
\text { expressed }\end{array}$ & -0.1899 & -0.15662 & 0.862359 & 0.098055 & 0.35525 & -0.1822 \\
\hline LOC_Os05g34210 & expressed protein & -0.4021 & -0.23351 & 0.860503 & 0.035063 & 0.645 & \\
\hline LOC_Os08g40620 & $\begin{array}{l}\text { rabGAP/TBC domain-containing } \\
\text { protein, putative, expressed }\end{array}$ & -0.53594 & 0.059602 & 0.859402 & 0.128107 & 0.758 & 0.17955 \\
\hline LOC_Os01g64930 & expressed protein & -0.12075 & 0.040431 & 0.858285 & -0.08236 & -0.31309 & -0.11055 \\
\hline LOC_Os04g52400 & $\begin{array}{l}\text { oxidoreductase, short chain } \\
\text { dehydrogenase/reductase family } \\
\text { protein, putative, expressed }\end{array}$ & -0.27208 & 0.036475 & 0.857444 & 0.072639 & -0.02725 & -0.13495 \\
\hline LOC_Os10g35490 & $\begin{array}{l}\text { hydrolase, alpha/beta fold family } \\
\text { domain containing protein, } \\
\text { expressed }\end{array}$ & 0.054089 & -0.76912 & 0.855528 & -0.92646 & -0.08981 & -0.4031 \\
\hline LOC_Os02g08440 & WRKY71, expressed & -0.47413 & 0.007454 & 0.854112 & 2.052449 & 0.973375 & 1.6468 \\
\hline LOC_Os09g32690 & $\begin{array}{l}\text { zinc finger, } \mathrm{C} 3 \mathrm{HC} 4 \text { type domain } \\
\text { containing protein, expressed }\end{array}$ & -0.5495 & -0.27768 & 0.854035 & -0.31063 & 0.089263 & -0.13275 \\
\hline LOC_Os12g02700 & $\begin{array}{l}\text { harpin-induced protein } 1 \text { domain } \\
\text { containing protein, expressed }\end{array}$ & -0.28076 & 0.004513 & 0.852895 & -0.07453 & 1.044563 & 0.29895 \\
\hline LOC_Os04g57210 & actin-6, putative, expressed & -0.35831 & 0.178287 & 0.850886 & 0.074543 & -0.146 & 0.90795 \\
\hline LOC_Os02g04260 & expressed protein & -0.51645 & 0.132159 & 0.848921 & -0.2984 & -0.17863 & -0.5867 \\
\hline LOC_Os03g38020 & $\begin{array}{l}\text { mps one binder kinase activator-like } \\
\text { 1A, putative, expressed }\end{array}$ & -0.18298 & -0.01507 & 0.848658 & -0.14961 & -0.23475 & -0.36265 \\
\hline LOC_Os01g43420 & expressed protein & -0.21818 & 0.288031 & 0.848465 & 0.077794 & -0.016 & 0.1221 \\
\hline LOC_Os08g04840 & $\begin{array}{l}\text { MYB family transcription factor, } \\
\text { putative, expressed }\end{array}$ & 0.011449 & 0.106286 & 0.847558 & -0.14165 & -0.74614 & 0.1596 \\
\hline LOC_Os01g64650 & $\begin{array}{l}\text { VAMP-like protein YKT62, } \\
\text { putative, expressed }\end{array}$ & -0.31844 & -0.50098 & 0.845032 & -0.04264 & 0.3475 & 0.45925 \\
\hline LOC_Os01g70980 & expressed protein & 0.049629 & 0.064648 & 0.843423 & 0.062306 & 0.379625 & 0.055 \\
\hline LOC_Os03g56860 & expressed protein & 0.016011 & -0.42589 & 0.842445 & 0.57521 & 1.024925 & \\
\hline LOC_Os03g48930 & $\begin{array}{l}\text { peptidase, T1 family, putative, } \\
\text { expressed }\end{array}$ & -0.3156 & -0.01438 & 0.842149 & -0.07643 & 0.335875 & -0.12655 \\
\hline LOC_Os03g59090 & $\begin{array}{l}\text { retrotransposon protein, putative, } \\
\text { unclassified, expressed }\end{array}$ & -0.17188 & -0.20476 & 0.841384 & -0.31224 & -2.00045 & \\
\hline LOC_Os03g17590 & $\begin{array}{l}\text { cat eye syndrome critical region } \\
\text { protein } 5 \text { precursor, putative, } \\
\text { expressed }\end{array}$ & 0.030441 & -0.19414 & 0.84115 & -0.13114 & -0.73764 & -0.0591 \\
\hline LOC_Os04g39290 & $\begin{array}{l}\text { heavy metal transport/detoxification } \\
\text { protein, putative, expressed }\end{array}$ & -0.00431 & 0.263241 & 0.840143 & & & \\
\hline LOC_Os06g35160 & $\begin{array}{l}\text { CAMK_KIN1/SNF1/Nim1_like.26 } \\
\text { - CAMK includes } \\
\text { calcium/calmodulin depedent } \\
\text { protein kinases, expressed }\end{array}$ & -0.32916 & -0.09363 & 0.840086 & -0.49926 & -1.94425 & -0.557 \\
\hline LOC_Os02g47000 & expressed protein & -0.43421 & -0.18495 & 0.837074 & -0.32926 & -0.27038 & \\
\hline LOC_Os03g01880 & $\begin{array}{l}\text { possible lysine decarboxylase } \\
\text { domain containing protein, } \\
\text { expressed }\end{array}$ & 0.152933 & -0.44603 & 0.830364 & -0.06343 & 1.963125 & -1.24905 \\
\hline LOC_Os08g06140 & $\begin{array}{l}\text { no apical meristem protein, putative, } \\
\text { expressed }\end{array}$ & -0.43648 & -0.21526 & 0.827665 & 0.229323 & 0.58575 & 0.52855 \\
\hline LOC_Os07g23550 & expressed protein & -0.26275 & -0.16058 & 0.826972 & -0.09168 & -0.248 & 0.15645 \\
\hline LOC_Os01g70550 & $\begin{array}{l}\text { heparan-alpha-glucosaminide } \\
\text { N-acetyltransferase, putative, } \\
\text { expressed }\end{array}$ & 0.021875 & -0.22136 & 0.826637 & -0.05771 & -1.7656 & -0.47855 \\
\hline LOC_Os07g31340 & $\begin{array}{l}\text { regulator of nonsense transcripts } 1 \text {, } \\
\text { putative, expressed }\end{array}$ & -0.24961 & -0.15508 & 0.82605 & -0.00124 & -0.10788 & \\
\hline LOC_Os01g56180 & expressed protein & 0.145358 & -0.29868 & 0.825376 & -0.19569 & 0.951225 & 0.64425 \\
\hline LOC_Os02g32730 & $\begin{array}{l}\text { neutral/alkaline invertase, putative, } \\
\text { expressed }\end{array}$ & -0.57031 & -0.0594 & 0.822657 & 0.202511 & -0.30475 & \\
\hline
\end{tabular}




\begin{tabular}{|c|c|c|c|c|c|c|c|}
\hline LOC_Os03g52010 & $\begin{array}{l}\text { lecithin cholesterol acyltransferase, } \\
\text { putative, expressed }\end{array}$ & 0.398442 & 0.338636 & 0.819373 & $3.75 \mathrm{E}-04$ & -0.94103 & -0.33725 \\
\hline LOC_Os01g04930 & $\begin{array}{l}\text { MYB family transcription factor, } \\
\text { putative, expressed }\end{array}$ & -0.01295 & 0.055304 & 0.819314 & -0.22055 & 0.140738 & -0.2583 \\
\hline LOC_Os01g04350 & $\begin{array}{l}\text { hsp } 20 / \text { alpha crystallin family } \\
\text { protein, putative, expressed }\end{array}$ & -0.24291 & 0.223939 & 0.816001 & -0.1836 & -0.29675 & 1.58775 \\
\hline LOC_Os03g04770 & beta-amylase, putative, expressed & -0.22317 & 0.02765 & 0.814081 & -0.70403 & -2.76675 & 0.55655 \\
\hline LOC_Os10g42100 & pyruvate kinase, putative, expressed & -0.2822 & -0.03503 & 0.813794 & -0.18236 & 0.21125 & -0.297 \\
\hline LOC_Os04g35190 & $\begin{array}{l}\text { OsFBX133 - F-box domain } \\
\text { containing protein, expressed }\end{array}$ & -0.21578 & -0.0268 & 0.812853 & -0.13265 & -0.23963 & -0.48655 \\
\hline LOC_Os06g49030 & $\begin{array}{l}\text { activator of } 90 \mathrm{kDa} \text { heat shock } \\
\text { protein ATPase homolog, putative, } \\
\text { expressed }\end{array}$ & -0.18459 & -0.07275 & 0.809719 & -0.14561 & 0.85225 & -0.0357 \\
\hline LOC_Os03g50540 & $\begin{array}{l}2 \mathrm{Fe}-2 \mathrm{~S} \text { iron-sulfur cluster binding } \\
\text { domain containing protein, } \\
\text { expressed }\end{array}$ & -0.4094 & 0.023369 & 0.809633 & -0.18206 & 0.28075 & -0.34695 \\
\hline LOC_Os02g56900 & $\begin{array}{l}\text { thioredoxin family protein, putative, } \\
\text { expressed }\end{array}$ & -0.07804 & 0.198618 & 0.808507 & 0.47091 & 1.566088 & 0.61405 \\
\hline LOC_Os02g 38020 & $\begin{array}{l}\text { inorganic phosphate transporter 2-1, } \\
\text { chloroplast precursor, putative, } \\
\text { expressed }\end{array}$ & -0.56644 & -1.41308 & 0.807135 & 0.136627 & -2.89613 & -0.35445 \\
\hline LOC_Os08g41250 & $\begin{array}{l}\text { signal recognition particle receptor } \\
\text { subunit beta, putative, expressed }\end{array}$ & -0.35516 & 0.39582 & 0.806449 & 0.139672 & 0.804288 & 0.13225 \\
\hline LOC_Os02g34950 & $\begin{array}{l}\text { ATP binding protein, putative, } \\
\text { expressed }\end{array}$ & -0.22906 & 0.012093 & 0.805621 & -0.11701 & -0.22088 & -0.16445 \\
\hline LOC_Os03g27280 & $\begin{array}{l}\text { CAMK_CAMK_like.19 - CAMK } \\
\text { includes calcium/calmodulin } \\
\text { depedent protein kinases, expressed }\end{array}$ & -0.1623 & -0.30819 & 0.803886 & 1.188188 & 0.266875 & 0.8234 \\
\hline LOC_Os03g50160 & $\begin{array}{l}\text { plastocyanin-like domain containing } \\
\text { protein, putative, expressed }\end{array}$ & 0.169646 & 0.400857 & 0.792071 & -0.10237 & -1.30999 & -0.031 \\
\hline LOC_Os01g28500 & $\begin{array}{l}\text { SCP-like extracellular protein, } \\
\text { expressed }\end{array}$ & -1.27654 & 0.156779 & 0.510968 & 0.319973 & 3.092325 & \\
\hline LOC_Os01g01280 & expressed protein & -0.92657 & -0.76745 & 0.565966 & 0.107372 & -1.52293 & \\
\hline LOC_Os08g44850 & $\begin{array}{l}\mathrm{C} 2 \text { domain containing protein, } \\
\text { putative, expressed }\end{array}$ & -1.10551 & -0.42785 & 0.561437 & 0.208983 & -0.12338 & 1.02175 \\
\hline LOC_Os04g49450 & $\begin{array}{l}\text { MYB family transcription factor, } \\
\text { putative, expressed }\end{array}$ & -1.20391 & -1.44493 & 0.546397 & 1.502378 & -0.90873 & 0.78825 \\
\hline LOC_Os11g42970 & $\begin{array}{l}\text { membrane associated DUF588 } \\
\text { domain containing protein, putative, } \\
\text { expressed }\end{array}$ & -0.94065 & -0.40201 & 0.537829 & 0.430146 & -0.32045 & 0.16165 \\
\hline LOC_Os01g04950 & $\begin{array}{l}\text { peptide transporter PTR2, putative, } \\
\text { expressed }\end{array}$ & -0.8949 & -0.26131 & 0.508428 & 0.084373 & -0.85049 & -0.0532 \\
\hline LOC_Os08g09840 & WRKY117, expressed & -1.17757 & 0.446533 & 0.486271 & & & \\
\hline LOC_Os01g26240 & $\begin{array}{l}\text { retrotransposon protein, putative, } \\
\text { Ty1-copia subclass, expressed }\end{array}$ & -0.9164 & 0.283896 & 0.485366 & & & \\
\hline LOC_Os04g32110 & $\begin{array}{l}\text { ACT domain containing protein, } \\
\text { expressed }\end{array}$ & -0.9244 & -1.19439 & 0.484351 & 1.49141 & 0.968438 & \\
\hline LOC_Os $03 \mathrm{~g} 25500$ & $\begin{array}{l}\text { cytochrome P450 72A1, putative, } \\
\text { expressed }\end{array}$ & -0.87996 & -0.02776 & 0.474355 & -0.03431 & 0.021075 & 1.43285 \\
\hline LOC_Os05g48390 & $\begin{array}{l}\text { ubiquitin conjugating enzyme } \\
\text { protein, putative, expressed }\end{array}$ & -0.8938 & 0.022004 & 0.470622 & -0.12392 & 0.313725 & \\
\hline LOC_Os01g51410 & $\begin{array}{l}\text { glycine dehydrogenase, putative, } \\
\text { expressed }\end{array}$ & -1.17287 & -0.1527 & 0.463928 & -0.07181 & -2.65488 & -0.46645 \\
\hline LOC_Os05g05950 & TOC159, putative, expressed & -0.94748 & 0.37116 & 0.459822 & -0.04824 & -0.42888 & -0.5627 \\
\hline LOC_Os04g53860 & reductase, putative, expressed & -0.81926 & 0.150901 & 0.44403 & -0.10544 & -0.57735 & 0.2428 \\
\hline
\end{tabular}




\begin{tabular}{|c|c|c|c|c|c|c|c|}
\hline LOC_Os07g18240 & $\begin{array}{l}\text { lectin-like receptor kinase, putative, } \\
\text { expressed }\end{array}$ & -0.91644 & -0.16499 & 0.438785 & & & \\
\hline LOC_Os04g42480 & $\begin{array}{l}\text { receptor-like protein kinase } \\
\text { At3g46290 precursor, putative, } \\
\text { expressed }\end{array}$ & -0.95343 & 0.165115 & 0.434655 & 0.549117 & 0.2085 & 1.0897 \\
\hline LOC_Os10g03570 & RGH1A, putative, expressed & -0.85295 & -0.12991 & 0.433056 & & & \\
\hline LOC_Os09g18594 & $\begin{array}{l}\text { protein kinase domain containing } \\
\text { protein, expressed }\end{array}$ & -1.22572 & 0.38545 & 0.393538 & 0.771443 & -0.51548 & -0.0381 \\
\hline LOC_Os10g22560 & $\begin{array}{l}\text { peptide transporter PTR2, putative, } \\
\text { expressed }\end{array}$ & -0.8836 & -0.18276 & 0.345746 & 0.105738 & -0.06888 & -0.29805 \\
\hline LOC_Os04g41960 & $\begin{array}{l}\text { NADP-dependent oxidoreductase, } \\
\text { putative, expressed }\end{array}$ & -1.19039 & -0.15611 & 0.344807 & 1.916629 & 0.384375 & 1.30305 \\
\hline LOC_Os09g25760 & $\begin{array}{l}\text { tetraspanin family protein, putative, } \\
\text { expressed }\end{array}$ & -0.80015 & -0.21851 & 0.337457 & 0.601217 & 0.148125 & \\
\hline LOC_Os07g12890 & $\begin{array}{l}\text { metal cation transporter, putative, } \\
\text { expressed }\end{array}$ & -0.99955 & 0.583405 & 0.327977 & 1.680573 & -1.00849 & \\
\hline LOC_Os11g07020 & $\begin{array}{l}\text { fructose-bisphospate aldolase } \\
\text { isozyme, putative, expressed }\end{array}$ & -1.00126 & -0.39168 & 0.323839 & -0.45039 & -2.11388 & -0.22875 \\
\hline LOC_Os06g40640 & $\begin{array}{l}\text { fructose-bisphospate aldolase } \\
\text { isozyme, putative, expressed }\end{array}$ & -1.3972 & -1.39504 & 0.318024 & 0.156639 & -2.673 & 0.2687 \\
\hline LOC_Os07g47290 & $\begin{array}{l}\text { xylose isomerase, putative, } \\
\text { expressed }\end{array}$ & -0.8127 & 0.024919 & 0.284689 & 0.051438 & -0.41068 & -0.17735 \\
\hline LOC_Os10g41550 & beta-amylase, putative, expressed & -1.14388 & -1.25697 & 0.282577 & 0.85704 & 0.667575 & \\
\hline LOC_Os12g13350 & $\begin{array}{l}\text { retrotransposon protein, putative, } \\
\text { Ty1-copia subclass, expressed }\end{array}$ & -0.83569 & -0.74303 & 0.280265 & & & \\
\hline LOC_Os06g19444 & $\begin{array}{l}\mathrm{CCT} / \mathrm{B}-\text { box zinc finger protein, } \\
\text { putative, expressed }\end{array}$ & -1.61839 & -1.28844 & 0.274135 & 0.571109 & -0.24734 & \\
\hline LOC_Os03g28940 & $\begin{array}{l}\text { ZIM domain containing protein, } \\
\text { putative, expressed }\end{array}$ & -0.95214 & -0.65904 & 0.26272 & 1.480131 & 2.049875 & 0.3204 \\
\hline LOC_Os01g05530 & expressed protein & -0.91885 & -0.19477 & 0.25055 & -0.16191 & -0.06725 & -0.337 \\
\hline LOC_Os01g66820 & $\begin{array}{l}\text { inactive receptor kinase At1g27190 } \\
\text { precursor, putative, expressed }\end{array}$ & -0.82449 & 0.217705 & 0.248969 & 0.112999 & -0.24355 & \\
\hline LOC_Os04g54840 & $\begin{array}{l}\text { DNA-directed RNA polymerase } \\
\text { subunit, putative, expressed }\end{array}$ & -0.83773 & -0.17416 & 0.248168 & -0.15713 & -0.024 & -0.7632 \\
\hline LOC_Os01g36350 & $\begin{array}{l}\text { cytochrome } \mathrm{P} 450 \text {, putative, } \\
\text { expressed }\end{array}$ & -0.80902 & -0.7103 & 0.242662 & 0.088498 & -0.03906 & 1.0506 \\
\hline LOC_Os09g36680 & $\begin{array}{l}\text { ribonuclease } \mathrm{T} 2 \text { family domain } \\
\text { containing protein, expressed }\end{array}$ & -1.02395 & -1.30235 & 0.225962 & -0.66071 & -0.5 & -0.12115 \\
\hline LOC_Os08g17390 & expressed protein & -0.99865 & -1.02892 & 0.223714 & 0.119238 & -4.44279 & 0.1205 \\
\hline LOC_Os02g43370 & $\begin{array}{l}\text { transposon protein, putative, } \\
\text { unclassified, expressed }\end{array}$ & -1.00615 & -0.05865 & 0.221107 & -0.08313 & -0.04174 & \\
\hline LOC_Os01g56200 & $\begin{array}{l}\text { BTBA2 - Bric-a-Brac,Tramtrack, } \\
\text { Broad Complex BTB domain with } \\
\text { Ankyrin repeat region, expressed }\end{array}$ & -0.89483 & 0.112626 & 0.214182 & 0.603712 & 0.08725 & 0.59835 \\
\hline LOC_Os11g39190 & $\begin{array}{l}\text { NB-ARC domain containing } \\
\text { protein, putative, expressed }\end{array}$ & -0.90255 & -0.82414 & 0.198438 & 0.041085 & -1.09833 & -0.575 \\
\hline LOC_Os10g38292 & hypothetical protein & -0.86794 & -0.48054 & 0.197663 & & & 0.18515 \\
\hline LOC_Os01g41780 & expressed protein & -0.88313 & 0.00626 & 0.190092 & 0.204918 & -0.05775 & 1.37775 \\
\hline LOC_Os01g15490 & $\begin{array}{l}\text { phosphoadenosine phosphosulfate, } \\
\text { putative, expressed }\end{array}$ & -0.80472 & -0.56236 & 0.18581 & 0.204022 & -0.47325 & 0.5413 \\
\hline LOC_Os01g67054 & $\begin{array}{l}\text { calreticulin precursor protein, } \\
\text { putative, expressed }\end{array}$ & -1.02093 & 0.152575 & 0.176661 & 0.359649 & 0.6315 & 0.80815 \\
\hline LOC_Os06g39730 & hypothetical protein & -1.10294 & -0.74241 & 0.175028 & & & \\
\hline LOC_Os01g58020 & $\begin{array}{l}\text { ribulose bisphosphate carboxylase } \\
\text { large chain precursor, putative, } \\
\text { expressed }\end{array}$ & -1.13135 & -1.61236 & 0.16403 & & & \\
\hline
\end{tabular}




\begin{tabular}{|c|c|c|c|c|c|c|c|}
\hline LOC_Os11g05260 & $\begin{array}{l}\text { phosphoglycerate mutase, putative, } \\
\text { expressed }\end{array}$ & -0.91507 & -0.50071 & 0.138497 & -0.2328 & -1.23975 & 0.36745 \\
\hline LOC_Os01g03820 & $\begin{array}{l}\mathrm{C} 2 \text { domain containing protein, } \\
\text { putative, expressed }\end{array}$ & -1.04919 & 0.560898 & 0.115682 & -0.01628 & 0.023088 & \\
\hline LOC_Os01g22980 & $\begin{array}{l}\text { OsSCP3 - Putative Serine } \\
\text { Carboxypeptidase homologue, } \\
\text { expressed }\end{array}$ & -0.86341 & -0.61157 & 0.022632 & -0.27986 & -0.58364 & -0.0994 \\
\hline LOC_Os01g02570 & $\begin{array}{l}\text { protein kinase domain containing } \\
\text { protein, expressed }\end{array}$ & -0.88617 & 0.100562 & 0.014902 & 0.663198 & -0.07761 & \\
\hline LOC_Os02g49800 & $\begin{array}{l}\text { eukaryotic aspartyl protease domain } \\
\text { containing protein, expressed }\end{array}$ & -0.93869 & 0.344194 & -0.0015 & 0.372282 & 0.141625 & 0.1934 \\
\hline LOC_Os12g36110 & $\begin{array}{l}\text { calmodulin binding protein, } \\
\text { putative, expressed }\end{array}$ & -0.96476 & 0.497316 & -0.00529 & 1.124285 & -0.02036 & 1.90655 \\
\hline LOC_Os08g 15460 & $\begin{array}{l}\text { preprotein translocase subunit } \sec Y \text {, } \\
\text { putative, expressed }\end{array}$ & -0.80462 & -0.33823 & -0.00607 & -0.11058 & -2.64404 & -0.74025 \\
\hline LOC_Os02g49780 & expressed protein & -0.89868 & 0.276333 & -0.01359 & -0.14391 & -0.29863 & \\
\hline LOC_Os03g46440 & $\begin{array}{l}\text { BTBA4 - Bric-a-Brac,Tramtrack, } \\
\text { Broad Complex BTB domain with } \\
\text { Ankyrin repeat region, expressed }\end{array}$ & -1.03721 & 0.594456 & -0.02212 & 1.756894 & -0.02814 & \\
\hline LOC_Os05g 34630 & $\begin{array}{l}\text { hydrolase, alpha/beta fold family } \\
\text { domain containing protein, } \\
\text { expressed }\end{array}$ & -0.79664 & -0.47977 & -0.0314 & 0.102746 & -1.75278 & -0.3509 \\
\hline LOC_Os12g38170 & osmotin, putative, expressed & -0.83262 & -1.05173 & -0.04608 & 0.633234 & 1.955875 & 0.53475 \\
\hline LOC_Os12g19030 & copine, putative, expressed & -0.9805 & 0.596323 & -0.06467 & 0.49064 & 0.668888 & 0.12815 \\
\hline LOC_Os $12 \mathrm{~g} 17430$ & $\begin{array}{l}\text { NBS-LRR disease resistance } \\
\text { protein, putative, expressed }\end{array}$ & -0.90915 & -0.01035 & -0.06937 & & & \\
\hline LOC_Os06g 38450 & $\begin{array}{l}\text { vignain precursor, putative, } \\
\text { expressed }\end{array}$ & -0.99007 & 0.140468 & -0.1464 & 0.829805 & -1.6048 & -0.65525 \\
\hline LOC_Os12g39420 & $\begin{array}{l}\text { nucleobase-ascorbate transporter, } \\
\text { putative, expressed }\end{array}$ & -0.95533 & -0.05573 & -0.1547 & 0.219221 & -0.379 & 0.029 \\
\hline LOC_Os09g19380 & $\begin{array}{l}\text { receptor-like protein kinase } \\
\text { precursor, putative, expressed }\end{array}$ & -1.39523 & -0.19256 & -0.17787 & & & \\
\hline LOC_Os10g42410 & $\begin{array}{l}\text { zinc-binding protein, putative, } \\
\text { expressed }\end{array}$ & -0.82606 & -0.3669 & -0.2089 & 1.112846 & 0.637375 & \\
\hline LOC_Os02g14250 & $\begin{array}{l}\text { transposon protein, putative, } \\
\text { unclassified, expressed }\end{array}$ & -1.23327 & 0.526342 & -0.21481 & & & \\
\hline LOC_Os01g09540 & $\begin{array}{l}\text { HAD superfamily phosphatase, } \\
\text { putative, expressed }\end{array}$ & -0.90027 & -0.94828 & -0.21719 & 0.274522 & -2.80386 & 0.0606 \\
\hline LOC_Os01g18630 & $\begin{array}{l}\text { aspartic proteinase oryzasin-1 } \\
\text { precursor, putative, expressed }\end{array}$ & -1.14608 & 0.113063 & -0.21789 & -0.20188 & 0.015875 & -0.4473 \\
\hline LOC_Os09g19500 & $\begin{array}{l}\text { senescence-induced receptor-like } \\
\text { serine/threonine-protein kinase } \\
\text { precursor, putative, expressed }\end{array}$ & -1.13816 & -0.9396 & -0.23492 & -0.029 & -0.18153 & -0.1472 \\
\hline LOC_Os09g19390 & $\begin{array}{l}\text { senescence-induced receptor-like } \\
\text { serine/threonine-protein kinase } \\
\text { precursor, putative, expressed }\end{array}$ & -1.37248 & 0.38207 & -0.28151 & & & \\
\hline LOC_Os01g48300 & $\begin{array}{l}\text { ATP synthase protein I related, } \\
\text { putative, expressed }\end{array}$ & -0.91854 & -0.45885 & -0.33156 & -0.28296 & -0.16436 & -0.24695 \\
\hline LOC_Os07g 18230 & $\begin{array}{l}\text { lectin-like receptor kinase, putative, } \\
\text { expressed }\end{array}$ & -0.84463 & 0.413007 & -0.34929 & & & \\
\hline LOC_Os06g07932 & flavonol synthase/flavanone & -0.80454 & -0.38232 & -0.37278 & 0.95579 & 0.52 & \\
\hline LOC_Os02g20360 & $\begin{array}{l}\text { 3-hydroxylase, putative, expressed } \\
\text { tyrosine aminotransferase, putative, } \\
\text { expressed }\end{array}$ & -2.07831 & 0.31498 & -0.37521 & & & \\
\hline
\end{tabular}




\begin{tabular}{|c|c|c|c|c|c|c|c|}
\hline LOC_Os03g22050 & $\begin{array}{l}\text { CAMK_KIN1/SNF1/Nim1_like.16 } \\
\text { - CAMK includes } \\
\text { calcium/calmodulin depedent } \\
\text { protein kinases, expressed }\end{array}$ & -0.79706 & -0.19025 & -0.45877 & -0.82048 & -0.11495 & \\
\hline LOC_Os02g07690 & $\begin{array}{l}\text { VQ domain containing protein, } \\
\text { putative, expressed }\end{array}$ & -0.89399 & -0.11783 & -0.46589 & 1.091729 & 1.234625 & 1.87625 \\
\hline LOC_Os01g46720 & expressed protein & -1.02193 & 0.014271 & -0.4954 & 0.0631 & -0.07969 & 0.22795 \\
\hline LOC_Os02g07360 & $\begin{array}{l}\text { pentatricopeptide containing } \\
\text { protein, putative, expressed }\end{array}$ & -0.91086 & -0.6471 & -0.52923 & -0.38557 & -1.676 & 0.80255 \\
\hline LOC_Os04g10940 & expressed protein & -0.88186 & -0.49618 & -0.5622 & & & \\
\hline LOC_Os01g38229 & $\begin{array}{l}\text { peptidyl-prolyl isomerase, putative, } \\
\text { expressed }\end{array}$ & -1.07743 & 0.385145 & -0.57081 & 0.663906 & 0.222413 & 0.1631 \\
\hline LOC_Os04g47360 & $\begin{array}{l}\text { OsPOP9 - Putative Prolyl } \\
\text { Oligopeptidase homologue, } \\
\text { expressed }\end{array}$ & -0.88908 & -0.04737 & -0.57198 & 0.034263 & -0.0699 & 0.26605 \\
\hline LOC_Os02g14440 & $\begin{array}{l}\text { peroxidase precursor, putative, } \\
\text { expressed }\end{array}$ & -1.10051 & -2.13442 & -0.66823 & 0.356743 & -3.11048 & \\
\hline LOC_Os01g02780 & TAK33, putative, expressed & -1.22064 & -0.40119 & -0.85837 & 0.374814 & -0.2223 & \\
\hline LOC_Os11g32880 & $\begin{array}{l}\text { DEAD-box ATP-dependent RNA } \\
\text { helicase, putative, expressed }\end{array}$ & -0.89188 & -0.54618 & -0.93644 & -0.10063 & -1.08054 & \\
\hline LOC_Os04g21350 & $\begin{array}{l}\text { flowering promoting factor-like } 1 \text {, } \\
\text { putative, expressed }\end{array}$ & -0.84815 & -0.59328 & -1.26687 & 0.351238 & -2.08903 & \\
\hline LOC_Os01g22900 & $\begin{array}{l}\text { neutral/alkaline invertase, putative, } \\
\text { expressed }\end{array}$ & -1.57882 & -0.90151 & -1.26889 & 0.631526 & 1.450375 & 1.02665 \\
\hline LOC_Os03g47610 & $\begin{array}{l}\text { thiamine biosynthesis protein thiC, } \\
\text { putative, expressed }\end{array}$ & -1.40209 & -0.63 & -2.42225 & 0.069719 & -1.58694 & -0.87805 \\
\hline
\end{tabular}

Table S2. Detailed data used for GO enrichment analysis in Figure 4




Table S3. Gene list associated with 11 enriched GO terms in the biological process category

\begin{tabular}{|c|c|c|c|c|c|}
\hline Locus ID & RGAP Ver 6 Annotation & GO ID & GO Nam & & GO Type \\
\hline LOC_Os02g35039 & $\begin{array}{l}\text { NAD dependent epimerase/dehydratase family protein, } \\
\text { putative, expressed }\end{array}$ & GO:0044237 & $\begin{array}{l}\text { cellular } \\
\text { process }\end{array}$ & metabolic & $\begin{array}{l}\text { biological_pr } \\
\text { ocess }\end{array}$ \\
\hline LOC_Os02g39160 & $\begin{array}{l}\text { hydroxymethylbutenyl 4-diphosphate synthase, } \\
\text { putative, expressed }\end{array}$ & GO:0044237 & $\begin{array}{l}\text { cellular } \\
\text { process }\end{array}$ & metabolic & $\begin{array}{l}\text { biological_pr } \\
\text { ocess }\end{array}$ \\
\hline LOC_Os02g57180 & $\begin{array}{l}\text { NADH dehydrogenase } 1 \text { alpha subcomplex subunit } \\
9 \text {,mitochondrial precursor, putative, expressed }\end{array}$ & GO:0044237 & $\begin{array}{l}\text { cellular } \\
\text { process }\end{array}$ & metabolic & $\begin{array}{l}\text { biological_pr } \\
\text { ocess }\end{array}$ \\
\hline LOC_Os04g53810 & leucoanthocyanidin reductase, putative, expressed & GO:0044237 & $\begin{array}{l}\text { cellular } \\
\text { process }\end{array}$ & metabolic & $\begin{array}{l}\text { biological_pr } \\
\text { ocess }\end{array}$ \\
\hline LOC_Os08g34280 & cinnamoyl-CoA reductase, putative, expressed & GO:0044237 & $\begin{array}{l}\text { cellular } \\
\text { process }\end{array}$ & metabolic & $\begin{array}{l}\text { biological_pr } \\
\text { ocess }\end{array}$ \\
\hline LOC_Os10g28200 & $\begin{array}{l}\text { NAD dependent epimerase/dehydratase family protein, } \\
\text { putative, expressed }\end{array}$ & GO:0044237 & $\begin{array}{l}\text { cellular } \\
\text { process }\end{array}$ & metabolic & $\begin{array}{l}\text { biological_pr } \\
\text { ocess }\end{array}$ \\
\hline LOC_Os12g23180 & $\begin{array}{l}\text { 3-beta hydroxysteroid dehydrogenase/isomerase family } \\
\text { protein, putative, expressed }\end{array}$ & GO:0044237 & $\begin{array}{l}\text { cellular } \\
\text { process }\end{array}$ & metabolic & $\begin{array}{l}\text { biological_pr } \\
\text { ocess }\end{array}$ \\
\hline LOC_Os01g64110 & glycosyl hydrolase, putative, expressed & GO:0006032 & $\begin{array}{l}\text { chitin } \\
\text { process }\end{array}$ & catabolic & $\begin{array}{l}\text { biological_pr } \\
\text { ocess }\end{array}$ \\
\hline LOC_Os10g28080 & glycosyl hydrolase, putative, expressed & GO:0006032 & $\begin{array}{l}\text { chitin } \\
\text { process }\end{array}$ & catabolic & $\begin{array}{l}\text { biological_pr } \\
\text { ocess }\end{array}$ \\
\hline LOC_Os11g37950 & WIP3 - Wound-induced protein precursor, expressed & GO:0006032 & $\begin{array}{l}\text { chitin } \\
\text { process }\end{array}$ & catabolic & $\begin{array}{l}\text { biological_pr } \\
\text { ocess }\end{array}$ \\
\hline LOC_Os11g37960 & WIP4 - Wound-induced protein precursor, expressed & GO:0006032 & $\begin{array}{l}\text { chitin } \\
\text { process }\end{array}$ & catabolic & $\begin{array}{l}\text { biological_pr } \\
\text { ocess }\end{array}$ \\
\hline LOC_Os02g36140 & terpene synthase, putative, expressed & GO:0006952 & \multicolumn{2}{|c|}{ defense response } & $\begin{array}{l}\text { biological_pr } \\
\text { ocess }\end{array}$ \\
\hline LOC_Os03g03810 & $\begin{array}{l}\text { DEF8 - Defensin and Defensin-like DEFL family, } \\
\text { expressed }\end{array}$ & GO:0006952 & \multicolumn{2}{|c|}{ defense response } & $\begin{array}{l}\text { biological_pr } \\
\text { ocess }\end{array}$ \\
\hline LOC_Os03g18850 & $\begin{array}{l}\text { pathogenesis-related Bet v I family protein, putative, } \\
\text { expressed }\end{array}$ & GO:0006952 & \multicolumn{2}{|c|}{ defense response } & $\begin{array}{l}\text { biological_pr } \\
\text { ocess }\end{array}$ \\
\hline LOC_Os08g07330 & RGH1A, putative, expressed & GO:0006952 & \multicolumn{2}{|c|}{ defense response } & $\begin{array}{l}\text { biological_pr } \\
\text { ocess }\end{array}$ \\
\hline LOC_Os09g36300 & OsLonP4 - Putative Lon protease homologue, expressed & GO:0006952 & \multicolumn{2}{|c|}{ defense response } & $\begin{array}{l}\text { biological_pr } \\
\text { ocess }\end{array}$ \\
\hline LOC_Os11g11960 & disease resistance protein RPM1, putative, expressed & GO:0006952 & \multicolumn{2}{|c|}{ defense response } & $\begin{array}{l}\text { biological_pr } \\
\text { ocess }\end{array}$ \\
\hline LOC_Os11g12340 & disease resistance protein RPM1, putative, expressed & GO:0006952 & \multicolumn{2}{|c|}{ defense response } & $\begin{array}{l}\text { biological_pr } \\
\text { ocess }\end{array}$ \\
\hline LOC_Os12g09739 & $\begin{array}{l}\text { pollen signalling protein with adenylyl cyclase activity, } \\
\text { putative, expressed }\end{array}$ & GO:0006952 & \multicolumn{2}{|c|}{ defense response } & $\begin{array}{l}\text { biological_pr } \\
\text { ocess }\end{array}$ \\
\hline LOC_Os12g25170 & $\begin{array}{l}\text { NB-ARC domain containing disease resistance protein, } \\
\text { putative, expressed }\end{array}$ & GO:0006952 & \multicolumn{2}{|c|}{ defense response } & $\begin{array}{l}\text { biological_pr } \\
\text { ocess }\end{array}$ \\
\hline LOC_Os12g36830 & $\begin{array}{l}\text { pathogenesis-related Bet } \mathrm{v} \text { I family protein, putative, } \\
\text { expressed }\end{array}$ & GO:0006952 & \multicolumn{2}{|c|}{ defense response } & $\begin{array}{l}\text { biological_pr } \\
\text { ocess }\end{array}$ \\
\hline LOC_Os12g36860 & pathogenesis-related protein 10 , putative, expressed & GO:0006952 & \multicolumn{2}{|c|}{ defense response } & $\begin{array}{l}\text { biological_pr } \\
\text { ocess }\end{array}$ \\
\hline LOC_Os12g36880 & $\begin{array}{l}\text { pathogenesis-related Bet } \mathrm{v} \text { I family protein, putative, } \\
\text { expressed }\end{array}$ & GO:0006952 & \multicolumn{2}{|c|}{ defense response } & $\begin{array}{l}\text { biological_pr } \\
\text { ocess }\end{array}$ \\
\hline
\end{tabular}




\begin{tabular}{|c|c|c|c|c|}
\hline LOC_Os03g56280 & lactate/malate dehydrogenase, putative, expressed & GO:0006096 & glycolysis & $\begin{array}{l}\text { biological_pr } \\
\text { ocess }\end{array}$ \\
\hline LOC_Os03g56460 & glucose-6-phosphate isomerase, putative, expressed & GO:0006096 & glycolysis & $\begin{array}{l}\text { biological_pr } \\
\text { ocess }\end{array}$ \\
\hline LOC_Os04g32020 & $\begin{array}{l}\text { 2-oxoglutarate dehydrogenase E1 component, } \\
\text { mitochondrial precursor, putative, expressed }\end{array}$ & GO:0006096 & glycolysis & $\begin{array}{l}\text { biological_pr } \\
\text { ocess }\end{array}$ \\
\hline LOC_Os08g03290 & $\begin{array}{l}\text { glyceraldehyde-3-phosphate dehydrogenase, putative, } \\
\text { expressed }\end{array}$ & GO:0006096 & glycolysis & $\begin{array}{l}\text { biological_pr } \\
\text { ocess }\end{array}$ \\
\hline LOC_Os12g05110 & pyruvate kinase, putative, expressed & GO:0006096 & glycolysis & $\begin{array}{l}\text { biological_pr } \\
\text { ocess }\end{array}$ \\
\hline LOC_Os05g33570 & $\begin{array}{l}\text { pyruvate, phosphate dikinase, chloroplast precursor, } \\
\text { putative, expressed }\end{array}$ & GO:0008610 & $\begin{array}{l}\text { lipid biosynthetic } \\
\text { process }\end{array}$ & $\begin{array}{l}\text { biological_pr } \\
\text { ocess }\end{array}$ \\
\hline LOC_Os12g37260 & $\begin{array}{l}\text { lipoxygenase 2.1, chloroplast precursor, putative, } \\
\text { expressed }\end{array}$ & GO:0008610 & $\begin{array}{l}\text { lipid biosynthetic } \\
\text { process }\end{array}$ & $\begin{array}{l}\text { biological_pr } \\
\text { ocess }\end{array}$ \\
\hline LOC_Os12g37350 & lipozygenase protein, putative & GO:0008610 & $\begin{array}{l}\text { lipid biosynthetic } \\
\text { process }\end{array}$ & $\begin{array}{l}\text { biological_pr } \\
\text { ocess }\end{array}$ \\
\hline LOC_Os01g01710 & $\begin{array}{l}\text { 1-deoxy-D-xylulose 5-phosphate reductoisomerase, } \\
\text { chloroplast precursor, putative, expressed }\end{array}$ & GO:0008152 & metabolic process & $\begin{array}{l}\text { biological_pr } \\
\text { ocess }\end{array}$ \\
\hline LOC_Os01g13590 & isoflavone reductase homolog IRL, putative & GO:0008152 & metabolic process & $\begin{array}{l}\text { biological_pr } \\
\text { ocess }\end{array}$ \\
\hline LOC_Os01g53350 & $\begin{array}{l}\text { anthocyanidin 5,3-O-glucosyltransferase, putative, } \\
\text { expressed }\end{array}$ & GO:0008152 & metabolic process & $\begin{array}{l}\text { biological_pr } \\
\text { ocess }\end{array}$ \\
\hline LOC_Os01g58100 & polyphenol oxidase, putative & GO:0008152 & metabolic process & $\begin{array}{l}\text { biological_pr } \\
\text { ocess }\end{array}$ \\
\hline LOC_Os01g71350 & glycosyl hydrolases family 17 , putative, expressed & GO:0008152 & metabolic process & $\begin{array}{l}\text { biological_pr } \\
\text { ocess }\end{array}$ \\
\hline LOC_Os02g01150 & $\begin{array}{l}\text { erythronate-4-phosphate dehydrogenase domain } \\
\text { containing protein, expressed }\end{array}$ & GO:0008152 & metabolic process & $\begin{array}{l}\text { biological_pr } \\
\text { ocess }\end{array}$ \\
\hline LOC_Os02g08100 & AMP-binding domain containing protein, expressed & GO:0008152 & metabolic process & $\begin{array}{l}\text { biological_pr } \\
\text { ocess }\end{array}$ \\
\hline LOC_Os02g35039 & $\begin{array}{l}\text { NAD dependent epimerase/dehydratase family protein, } \\
\text { putative, expressed }\end{array}$ & GO:0008152 & metabolic process & $\begin{array}{l}\text { biological_pr } \\
\text { ocess }\end{array}$ \\
\hline LOC_Os02g36140 & terpene synthase, putative, expressed & GO:0008152 & metabolic process & $\begin{array}{l}\text { biological_pr } \\
\text { ocess }\end{array}$ \\
\hline LOC_Os02g48964 & WD-40 repeat family protein, putative, expressed & GO:0008152 & metabolic process & $\begin{array}{l}\text { biological_pr } \\
\text { ocess }\end{array}$ \\
\hline LOC_Os02g57180 & $\begin{array}{l}\text { NADH dehydrogenase } 1 \text { alpha subcomplex subunit } \\
9 \text {,mitochondrial precursor, putative, expressed }\end{array}$ & GO:0008152 & metabolic process & $\begin{array}{l}\text { biological_pr } \\
\text { ocess }\end{array}$ \\
\hline LOC_Os03g03720 & $\begin{array}{l}\text { glyceraldehyde-3-phosphate dehydrogenase, putative, } \\
\text { expressed }\end{array}$ & GO:0008152 & metabolic process & $\begin{array}{l}\text { biological_pr } \\
\text { ocess }\end{array}$ \\
\hline LOC_Os03g08999 & dehydrogenase, putative, expressed & GO:0008152 & metabolic process & $\begin{array}{l}\text { biological_pr } \\
\text { ocess }\end{array}$ \\
\hline LOC_Os03g09250 & inositol-3-phosphate synthase, putative, expressed & GO:0008152 & metabolic process & $\begin{array}{l}\text { biological_pr } \\
\text { ocess }\end{array}$ \\
\hline LOC_Os03g36750 & cbbY, putative, expressed & GO:0008152 & metabolic process & $\begin{array}{l}\text { biological_pr } \\
\text { ocess }\end{array}$ \\
\hline LOC_Os03g56280 & lactate/malate dehydrogenase, putative, expressed & GO:0008152 & metabolic process & $\begin{array}{l}\text { biological_pr } \\
\text { ocess }\end{array}$ \\
\hline
\end{tabular}




\begin{tabular}{|c|c|c|c|c|}
\hline LOC_Os04g15920 & dehydrogenase, putative, expressed & GO:0008152 & metabolic process & $\begin{array}{l}\text { biological_pr } \\
\text { ocess }\end{array}$ \\
\hline LOC_Os04g27340 & terpene synthase, putative, expressed & GO:0008152 & metabolic process & $\begin{array}{l}\text { biological_pr } \\
\text { ocess }\end{array}$ \\
\hline LOC_Os04g31700 & methylisocitrate lyase 2 , putative, expressed & GO:0008152 & metabolic process & $\begin{array}{l}\text { biological_pr } \\
\text { ocess }\end{array}$ \\
\hline LOC_Os04g32020 & $\begin{array}{l}\text { 2-oxoglutarate dehydrogenase E1 component, } \\
\text { mitochondrial precursor, putative, expressed }\end{array}$ & GO:0008152 & metabolic process & $\begin{array}{l}\text { biological_pr } \\
\text { ocess }\end{array}$ \\
\hline LOC_Os04g33190 & AMP-binding enzyme, putative, expressed & GO:0008152 & metabolic process & $\begin{array}{l}\text { biological_pr } \\
\text { ocess }\end{array}$ \\
\hline LOC_Os04g37619 & $\begin{array}{l}\text { zeaxanthin epoxidase, chloroplast precursor, putative, } \\
\text { expressed }\end{array}$ & GO:0008152 & metabolic process & $\begin{array}{l}\text { biological_pr } \\
\text { ocess }\end{array}$ \\
\hline LOC_Os04g53810 & leucoanthocyanidin reductase, putative, expressed & GO:0008152 & metabolic process & $\begin{array}{l}\text { biological_pr } \\
\text { ocess }\end{array}$ \\
\hline LOC_Os05g31140 & glycosyl hydrolases family 17 , putative, expressed & GO:0008152 & metabolic process & $\begin{array}{l}\text { biological_pr } \\
\text { ocess }\end{array}$ \\
\hline LOC_Os06g15990 & aldehyde dehydrogenase, putative, expressed & GO:0008152 & metabolic process & $\begin{array}{l}\text { biological_pr } \\
\text { ocess }\end{array}$ \\
\hline LOC_Os06g36840 & cysteine synthase, putative, expressed & GO:0008152 & metabolic process & $\begin{array}{l}\text { biological_pr } \\
\text { ocess }\end{array}$ \\
\hline LOC_Os07g05820 & hydroxyacid oxidase 1 , putative, expressed & GO:0008152 & metabolic process & $\begin{array}{l}\text { biological_pr } \\
\text { ocess }\end{array}$ \\
\hline LOC_Os07g06830 & gibberellin receptor GID1L2, putative, expressed & GO:0008152 & metabolic process & $\begin{array}{l}\text { biological_pr } \\
\text { ocess }\end{array}$ \\
\hline LOC_Os07g46460 & $\begin{array}{l}\text { ferredoxin-dependent glutamate synthase, chloroplast } \\
\text { precursor, putative, expressed }\end{array}$ & GO:0008152 & metabolic process & $\begin{array}{l}\text { biological_pr } \\
\text { ocess }\end{array}$ \\
\hline LOC_Os07g46520 & $\begin{array}{l}\text { rhythmically expressed gene } 2 \text { protein, putative, } \\
\text { expressed }\end{array}$ & GO:0008152 & metabolic process & $\begin{array}{l}\text { biological_pr } \\
\text { ocess }\end{array}$ \\
\hline LOC_Os07g46920 & $\begin{array}{l}\text { sex determination protein tasselseed-2, putative, } \\
\text { expressed }\end{array}$ & GO:0008152 & metabolic process & $\begin{array}{l}\text { biological_pr } \\
\text { ocess }\end{array}$ \\
\hline LOC_Os08g03290 & $\begin{array}{l}\text { glyceraldehyde-3-phosphate dehydrogenase, putative, } \\
\text { expressed }\end{array}$ & GO:0008152 & metabolic process & $\begin{array}{l}\text { biological_pr } \\
\text { ocess }\end{array}$ \\
\hline LOC_Os08g04500 & terpene synthase, putative, expressed & GO:0008152 & metabolic process & $\begin{array}{l}\text { biological_pr } \\
\text { ocess }\end{array}$ \\
\hline LOC_Os08g07080 & terpene synthase, putative, expressed & GO:0008152 & metabolic process & $\begin{array}{l}\text { biological_pr } \\
\text { ocess }\end{array}$ \\
\hline LOC_Os08g34280 & cinnamoyl-CoA reductase, putative, expressed & GO:0008152 & metabolic process & $\begin{array}{l}\text { biological_pr } \\
\text { ocess }\end{array}$ \\
\hline LOC_Os10g28080 & glycosyl hydrolase, putative, expressed & GO:0008152 & metabolic process & $\begin{array}{l}\text { biological_pr } \\
\text { ocess }\end{array}$ \\
\hline LOC_Os10g28200 & $\begin{array}{l}\text { NAD dependent epimerase/dehydratase family protein, } \\
\text { putative, expressed }\end{array}$ & GO:0008152 & metabolic process & $\begin{array}{l}\text { biological_pr } \\
\text { ocess }\end{array}$ \\
\hline LOC_Os11g07930 & $\begin{array}{l}\text { oxidoreductase, short chain dehydrogenase/reductase } \\
\text { family domain containing family, expressed }\end{array}$ & GO:0008152 & metabolic process & $\begin{array}{l}\text { biological_pr } \\
\text { ocess }\end{array}$ \\
\hline LOC_Os12g07110 & acyl-CoA synthetase protein, putative, expressed & GO:0008152 & metabolic process & $\begin{array}{l}\text { biological_pr } \\
\text { ocess }\end{array}$ \\
\hline LOC_Os12g12560 & NADP-dependent oxidoreductase, putative, expressed & GO:0008152 & metabolic process & $\begin{array}{l}\text { biological_pr } \\
\text { ocess }\end{array}$ \\
\hline
\end{tabular}




\begin{tabular}{|c|c|c|c|c|}
\hline LOC_Os12g23180 & $\begin{array}{l}\text { 3-beta hydroxysteroid dehydrogenase/isomerase family } \\
\text { protein, putative, expressed }\end{array}$ & GO:0008152 & metabolic process & $\begin{array}{l}\text { biological_pr } \\
\text { ocess }\end{array}$ \\
\hline LOC_Os01g13590 & isoflavone reductase homolog IRL, putative & GO:0006808 & $\begin{array}{l}\text { regulation of nitrogen } \\
\text { utilization }\end{array}$ & $\begin{array}{l}\text { biological_pr } \\
\text { ocess }\end{array}$ \\
\hline LOC_Os02g 57180 & $\begin{array}{l}\text { NADH dehydrogenase } 1 \text { alpha subcomplex subunit } \\
9 \text {,mitochondrial precursor, putative, expressed }\end{array}$ & GO:0006808 & $\begin{array}{l}\text { regulation of nitrogen } \\
\text { utilization }\end{array}$ & $\begin{array}{l}\text { biological_pr } \\
\text { ocess }\end{array}$ \\
\hline LOC_Os08g34280 & cinnamoyl-CoA reductase, putative, expressed & GO:0006808 & $\begin{array}{l}\text { regulation of nitrogen } \\
\text { utilization }\end{array}$ & $\begin{array}{l}\text { biological_pr } \\
\text { ocess }\end{array}$ \\
\hline LOC_Os03g18850 & $\begin{array}{l}\text { pathogenesis-related Bet v I family protein, putative, } \\
\text { expressed }\end{array}$ & GO:0009607 & $\begin{array}{l}\text { response to biotic } \\
\text { stimulus }\end{array}$ & $\begin{array}{l}\text { biological_pr } \\
\text { ocess }\end{array}$ \\
\hline LOC_Os $12 \mathrm{~g} 36830$ & $\begin{array}{l}\text { pathogenesis-related Bet v I family protein, putative, } \\
\text { expressed }\end{array}$ & GO:0009607 & $\begin{array}{l}\text { response to biotic } \\
\text { stimulus }\end{array}$ & $\begin{array}{l}\text { biological_pr } \\
\text { ocess }\end{array}$ \\
\hline LOC_Os12g36860 & pathogenesis-related protein 10 , putative, expressed & GO:0009607 & $\begin{array}{l}\text { response to biotic } \\
\text { stimulus }\end{array}$ & $\begin{array}{l}\text { biological_pr } \\
\text { ocess }\end{array}$ \\
\hline LOC_Os12g36880 & $\begin{array}{l}\text { pathogenesis-related Bet } v \text { I family protein, putative, } \\
\text { expressed }\end{array}$ & GO:0009607 & $\begin{array}{l}\text { response to biotic } \\
\text { stimulus }\end{array}$ & $\begin{array}{l}\text { biological_pr } \\
\text { ocess }\end{array}$ \\
\hline LOC_Os02g35039 & $\begin{array}{l}\text { NAD dependent epimerase/dehydratase family protein, } \\
\text { putative, expressed }\end{array}$ & GO:0006694 & $\begin{array}{l}\text { steroid } \\
\text { process }\end{array}$ & $\begin{array}{l}\text { biological_pr } \\
\text { ocess }\end{array}$ \\
\hline LOC_Os02g57180 & $\begin{array}{l}\text { NADH dehydrogenase } 1 \text { alpha subcomplex subunit } \\
9 \text {,mitochondrial precursor, putative, expressed }\end{array}$ & GO:0006694 & $\begin{array}{l}\text { steroid } \\
\text { process }\end{array}$ & $\begin{array}{l}\text { biological_pr } \\
\text { ocess }\end{array}$ \\
\hline LOC_Os08g34280 & cinnamoyl-CoA reductase, putative, expressed & GO:0006694 & $\begin{array}{l}\text { steroid } \\
\text { process }\end{array}$ & $\begin{array}{l}\text { biological_pr } \\
\text { ocess }\end{array}$ \\
\hline LOC_Os12g23180 & $\begin{array}{l}\text { 3-beta hydroxysteroid dehydrogenase/isomerase family } \\
\text { protein, putative, expressed }\end{array}$ & GO:0006694 & $\begin{array}{l}\text { steroid biosynthetic } \\
\text { process }\end{array}$ & $\begin{array}{l}\text { biological_pr } \\
\text { ocess }\end{array}$ \\
\hline LOC_Os01g64660 & fructose-1,6-bisphosphatase, putative, expressed & GO:0006810 & transport & $\begin{array}{l}\text { biological_pr } \\
\text { ocess }\end{array}$ \\
\hline LOC_Os02g43860 & amino acid permease, putative, expressed & GO:0006810 & transport & $\begin{array}{l}\text { biological_pr } \\
\text { ocess }\end{array}$ \\
\hline LOC_Os02g54730 & $\begin{array}{l}\text { transmembrane amino acid transporter protein, putative, } \\
\text { expressed }\end{array}$ & GO:0006810 & transport & $\begin{array}{l}\text { biological_pr } \\
\text { ocess }\end{array}$ \\
\hline LOC_Os03g05620 & inorganic phosphate transporter, putative, expressed & GO:0006810 & transport & $\begin{array}{l}\text { biological_pr } \\
\text { ocess }\end{array}$ \\
\hline LOC_Os03g12590 & coatomer subunit gamma-1, putative, expressed & GO:0006810 & transport & $\begin{array}{l}\text { biological_pr } \\
\text { ocess }\end{array}$ \\
\hline LOC_Os03g 37830 & potassium transporter, putative, expressed & GO:0006810 & transport & $\begin{array}{l}\text { biological_pr } \\
\text { ocess }\end{array}$ \\
\hline LOC_Os03g62200 & ammonium transporter protein, putative, expressed & GO:0006810 & transport & $\begin{array}{l}\text { biological_pr } \\
\text { ocess }\end{array}$ \\
\hline LOC_Os04g15920 & dehydrogenase, putative, expressed & GO:0006810 & transport & $\begin{array}{l}\text { biological_pr } \\
\text { ocess }\end{array}$ \\
\hline LOC_Os04g43070 & ammonium transporter protein, putative, expressed & GO:0006810 & transport & $\begin{array}{l}\text { biological_pr } \\
\text { ocess }\end{array}$ \\
\hline LOC_Os05g06350 & importin subunit alpha, putative, expressed & GO:0006810 & transport & $\begin{array}{l}\text { biological_pr } \\
\text { ocess }\end{array}$ \\
\hline LOC_Os07g26490 & ankyrin repeat domain containing protein, expressed & GO:0006810 & transport & $\begin{array}{l}\text { biological_pr } \\
\text { ocess }\end{array}$ \\
\hline LOC_Os07g36470 & vacuolar ATP synthase subunit $\mathrm{H}$, putative, expressed & GO:0006810 & transport & $\begin{array}{l}\text { biological_pr } \\
\text { ocess }\end{array}$ \\
\hline
\end{tabular}




\begin{tabular}{lllll}
\hline LOC_Os07g37320 & transporter family protein, putative, expressed & GO:0006810 & transport & \multicolumn{1}{c}{$\begin{array}{l}\text { biological_pr } \\
\text { ocess }\end{array}$} \\
LOC_Os08g31410 & sulfate transporter, putative, expressed & GO:0006810 & transport & $\begin{array}{l}\text { biological_pr } \\
\text { ocess }\end{array}$ \\
LOC_Os09g08390 & CRAL/TRIO domain containing protein, expressed & GO:0006810 & transport & biological_pr \\
ocess
\end{tabular}

Table S4. List and microarray data of 95 candidate genes associated with enhanced bacterial blight resistance from microarray experiments

\begin{tabular}{|c|c|c|c|c|c|c|c|c|}
\hline RGAP_Locus_ID & $\begin{array}{l}\text { MapMan } \\
\text { Classification }\end{array}$ & Putative Function & Feature & $\begin{array}{l}\log _{2} \\
\text { NRRox(SS)/ } \\
\text { LG(S)_1d }\end{array}$ & $\begin{array}{l}\log _{2} \\
\text { NH1ox(R)/ } \\
\text { LG(S)_1d }\end{array}$ & $\begin{array}{l}\log _{2} \text { Xa21(R)/ } \\
\text { TP309(S)_2d }\end{array}$ & $\begin{array}{l}\log _{2} \text { BTH/ } \\
\text { SA(hormone) } \\
\text { /Mock }\end{array}$ & $\begin{array}{l}\log _{2} \\
\text { JA(hormone) } \\
\text { /Mock_leaf }\end{array}$ \\
\hline LOC_Os11g11960 & $\begin{array}{l}\text { Stress Biotic: } \\
\text { Disease resistance }\end{array}$ & $\begin{array}{l}\text { disease resistance } \\
\text { protein RPM1 }\end{array}$ & NRR, NH1 & -1.008 & 0.903 & 0.399 & & \\
\hline LOC_Os11g12340 & $\begin{array}{l}\text { Stress Biotic: } \\
\text { Disease resistance }\end{array}$ & $\begin{array}{l}\text { disease resistance } \\
\text { protein RPM1 }\end{array}$ & NRR, NH1 & -1.245 & 0.871 & -0.18 & 1.657 & -0.57 \\
\hline LOC_Os12g25170 & $\begin{array}{l}\text { Stress Biotic: } \\
\text { Disease resistance }\end{array}$ & $\begin{array}{l}\text { NB-ARC domain } \\
\text { containing } \\
\text { disease resistance } \\
\text { protein }\end{array}$ & $\begin{array}{l}\text { NRR, NH1, } \\
\text { Xa21 }\end{array}$ & -0.815 & 0.799 & 1.148 & 0.2 & -0.75 \\
\hline LOC_Os08g07330 & $\begin{array}{l}\text { Stress Biotic: } \\
\text { Disease resistance }\end{array}$ & RGH1A & NH1, Xa21 & -0.593 & 0.637 & 0.913 & 0.255 & 0.18 \\
\hline LOC_Os02g43360 & $\begin{array}{l}\text { Redox: Respiratory } \\
\text { burst }\end{array}$ & $\begin{array}{l}\text { cytochrome } \\
\text { b5-like Heme }\end{array}$ & NH1, Xa21 & -0.299 & 0.621 & 1.187 & -0.06 & 0.72 \\
\hline LOC_Os10g28200 & $\begin{array}{l}\text { Redox: Respiratory } \\
\text { burst }\end{array}$ & $\begin{array}{l}\text { NAD dependent } \\
\text { epimerase }\end{array}$ & NRR, Xa21 & -0.77 & -0.84 & 1.239 & 0.625 & -0.53 \\
\hline LOC_Os12g08810 & $\begin{array}{l}\text { Redox: Respiratory } \\
\text { burst }\end{array}$ & VTC2 & NH1, Xa21 & 0.065 & 1.364 & 1.038 & -0.19 & 0.73 \\
\hline LOC_Os07g48020 & $\begin{array}{l}\text { Misc: Respiratory } \\
\text { burst }\end{array}$ & $\begin{array}{l}\text { peroxidase } \\
\text { precursor }\end{array}$ & NH1, Xa21 & -0.394 & 1.416 & 2.109 & 1.746 & -1.79 \\
\hline LOC_Os07g48050 & $\begin{array}{l}\text { Misc: Respiratory } \\
\text { burst }\end{array}$ & $\begin{array}{l}\text { peroxidase } \\
\text { precursor }\end{array}$ & NH1, Xa21 & -0.161 & .969 & 2.452 & 2.279 & -0.91 \\
\hline LOC_Os07g28480 & Misc: Respiratory & glutathione & NRR, Xa21 & -0.812 & -1.14 & 1.079 & 0.27 & -1.92 \\
\hline
\end{tabular}




\begin{tabular}{|c|c|c|c|c|c|c|c|c|}
\hline & burst & S-transferase & & & & & & \\
\hline LOC_Os09g29200 & $\begin{array}{l}\text { Misc: Respiratory } \\
\text { burst }\end{array}$ & $\begin{array}{l}\text { glutathione } \\
\text { S-transferase }\end{array}$ & $\begin{array}{l}\text { NRR, NH1, } \\
\text { Xa21 }\end{array}$ & -1.057 & 0.88 & 0.982 & 1.166 & -0.06 \\
\hline LOC_Os04g37619 & $\begin{array}{l}\text { Hormone } \\
\text { Metabolism: ABA }\end{array}$ & $\begin{array}{l}\text { zeaxanthin } \\
\text { epoxidase }\end{array}$ & NRR, Xa21 & -0.631 & -0.11 & 1.08 & -0.39 & 0.433 \\
\hline LOC_Os02g47510 & $\begin{array}{l}\text { Hormone } \\
\text { Metabolism: ABA }\end{array}$ & $\begin{array}{l}\text { 9-cis-epoxycarote } \\
\text { noid dioxygenase } \\
1\end{array}$ & NRR, Xa21 & -0.89 & -0.71 & 0.944 & -0.11 & -1.44 \\
\hline LOC_Os04g49194 & $\begin{array}{l}\text { Hormone } \\
\text { Metabolism: } \\
\text { Ethylene }\end{array}$ & $\begin{array}{l}\text { naringenin,2-oxo } \\
\text { glutarate } \\
\text { 3-dioxygenase }\end{array}$ & NRR, NH1 & -0.84 & 0.663 & 0.398 & 0.941 & 0.89 \\
\hline LOC_Os04g49210 & $\begin{array}{l}\text { Hormone } \\
\text { Metabolism: } \\
\text { Ethylene }\end{array}$ & $\begin{array}{l}\text { naringenin,2-oxo } \\
\text { glutarate } \\
\text { 3-dioxygenase }\end{array}$ & NH1, Xa21 & -0.31 & 1.544 & 0.818 & 3.918 & 0.636 \\
\hline LOC_Os10g39140 & $\begin{array}{l}\text { Hormone } \\
\text { Metabolism: } \\
\text { Ethylene }\end{array}$ & $\begin{array}{l}\text { flavonol } \\
\text { synthase/flavanon } \\
\text { e 3-hydroxylase }\end{array}$ & NRR, NH1 & -0.773 & 1.515 & -0.05 & 3.239 & 2.323 \\
\hline LOC_Os08g26820 & $\begin{array}{l}\text { Hormone } \\
\text { Metabolism: } \\
\text { Ethylene }\end{array}$ & $\begin{array}{l}\text { unknown } \\
\text { function domain } \\
\text { containing } \\
\text { protein }\end{array}$ & NRR, NH1 & -0.822 & 0.613 & -0.64 & 1.824 & -0.42 \\
\hline LOC_Os08g26840 & $\begin{array}{l}\text { Hormone } \\
\text { Metabolism: } \\
\text { Ethylene }\end{array}$ & $\begin{array}{l}\text { unknown } \\
\text { function domain } \\
\text { containing } \\
\text { protein }\end{array}$ & NRR, NH1 & -0.935 & 0.608 & -0.78 & 2.433 & 0.314 \\
\hline LOC_Os12g37260 & $\begin{array}{l}\text { Hormone } \\
\text { Metabolism: JA }\end{array}$ & $\begin{array}{l}\text { lipoxygenase } 2.1 \text {, } \\
\text { chloroplast } \\
\text { precursor }\end{array}$ & NH1, Xa21 & -0.565 & 2.815 & 2.427 & 3.154 & 1.946 \\
\hline LOC_Os12g37350 & $\begin{array}{l}\text { Hormone } \\
\text { Metabolism: JA }\end{array}$ & $\begin{array}{l}\text { lipozygenase } \\
\text { protein }\end{array}$ & NH1, Xa21 & -0.162 & 1.039 & 0.771 & 2.682 & 1.506 \\
\hline LOC_Os03g32314 & $\begin{array}{l}\text { Hormone } \\
\text { Metabolism: JA }\end{array}$ & $\begin{array}{l}\text { allene oxide } \\
\text { cyclase } 4\end{array}$ & NRR, Xa21 & -0.706 & -0 & 1.094 & 0.027 & 1.532 \\
\hline LOC_Os02g48770 & $\begin{array}{l}\text { Hormone } \\
\text { Metabolism: SA }\end{array}$ & $\begin{array}{l}\text { SAM dependent } \\
\text { carboxyl } \\
\text { methyltransferase }\end{array}$ & NH1, Xa21 & -0.002 & 1.239 & 1.461 & 0.693 & 3.978 \\
\hline LOC_Os05g01140 & $\begin{array}{l}\text { Hormone } \\
\text { Metabolism: SA }\end{array}$ & methyltransferase & NH1, Xa21 & 0.163 & 1.246 & 1.775 & 0.23 & -0.01 \\
\hline LOC_Os03g10880 & Signalling & BTBN5 & NRR, Xa21 & -0.971 & -1.08 & 1.268 & 0.047 & -1.05 \\
\hline LOC_Os01g04280 & Signalling: Calcium & $\begin{array}{l}\text { calmodulin } \\
\text { binding protein }\end{array}$ & NRR, NH1 & -0.836 & 0.998 & -0.22 & 1.556 & 0.374 \\
\hline LOC_Os02g08120 & Signalling: Calcium & $\begin{array}{l}\text { calmodulin } \\
\text { binding protein }\end{array}$ & NRR, Xa21 & -0.836 & -0.05 & 0.975 & 0.068 & -0.15 \\
\hline LOC_Os04g32950 & Signalling: Calcium & $\begin{array}{l}\text { calreticulin } \\
\text { precursor protein }\end{array}$ & NRR, Xa21 & -1.003 & 0.264 & 1.177 & 0.432 & 1.291 \\
\hline LOC_Os05g43170 & Signalling: Calcium & $\begin{array}{l}\text { calreticulin } \\
\text { precursor protein }\end{array}$ & NRR, Xa21 & -1.296 & -0.1 & 0.986 & 0.707 & 0.022 \\
\hline LOC_Os02g48000 & Signalling: & TBC domain & NRR, Xa21 & -0.885 & -0.02 & 0.754 & -0.01 & 1.199 \\
\hline
\end{tabular}




\begin{tabular}{|c|c|c|c|c|c|c|c|c|}
\hline & G-protein & $\begin{array}{l}\text { containing } \\
\text { protein }\end{array}$ & & & & & & \\
\hline LOC_Os12g31440 & $\begin{array}{l}\text { Signalling: } \\
\text { G-protein }\end{array}$ & expressed protein & NRR, Xa21 & -0.73 & -0.07 & 0.926 & -0.05 & -0.19 \\
\hline LOC_Os07g03900 & $\begin{array}{l}\text { Signalling: } \\
\text { Receptor kinases }\end{array}$ & $\begin{array}{l}\text { lectin-like } \\
\text { receptor kinase }\end{array}$ & NH1, Xa21 & -0.175 & 0.938 & 0.829 & -0.02 & -0.08 \\
\hline LOC_Os11g39370 & $\begin{array}{l}\text { Signalling: } \\
\text { Receptor kinases }\end{array}$ & $\begin{array}{l}\text { BRASSINOSTE } \\
\text { ROID } \\
\text { INSENSITIVE } 1\end{array}$ & $\begin{array}{l}\text { NRR, NH1, } \\
\text { Xa21 }\end{array}$ & -1.042 & 1.829 & 0.781 & 0.943 & 0.155 \\
\hline LOC_Os02g02120 & $\begin{array}{l}\text { Signalling: } \\
\text { Receptor kinases }\end{array}$ & OsWAK11 & $\begin{array}{l}\text { NRR, NH1, } \\
\text { Xa21 }\end{array}$ & -1.136 & 0.985 & 0.673 & 0.413 & -0.06 \\
\hline LOC_Os05g34270 & $\begin{array}{l}\text { Signalling: } \\
\text { Receptor kinases }\end{array}$ & $\begin{array}{l}\text { inactive receptor } \\
\text { kinase }\end{array}$ & NRR, NH1 & -1.018 & 0.821 & 0.305 & 0.811 & 0.288 \\
\hline LOC_Os05g40270 & $\begin{array}{l}\text { Signalling: } \\
\text { Receptor kinases }\end{array}$ & expressed protein & NH1, Xa21 & -0.58 & 0.814 & 0.644 & -0.15 & -1.21 \\
\hline LOC_Os09g39650 & $\begin{array}{l}\text { Signalling: } \\
\text { Receptor kinases }\end{array}$ & $\begin{array}{l}\text { protein kinase } \\
\text { family protein }\end{array}$ & $\begin{array}{l}\text { NRR, NH1, } \\
\text { Xa21 }\end{array}$ & -0.932 & 1.144 & 0.855 & 0.299 & -0.3 \\
\hline LOC_Os11g39370 & $\begin{array}{l}\text { Signalling: } \\
\text { Receptor kinases }\end{array}$ & $\begin{array}{l}\text { BRASSINOSTE } \\
\text { ROID } \\
\text { INSENSITIVE } 1\end{array}$ & $\begin{array}{l}\text { NRR, NH1, } \\
\text { Xa21 }\end{array}$ & -1.042 & 1.829 & 0.781 & 0.943 & 0.155 \\
\hline LOC_Os11g46810 & $\begin{array}{l}\text { Signalling: } \\
\text { Receptor kinases }\end{array}$ & $\begin{array}{l}\text { retrotransposon } \\
\text { protein }\end{array}$ & NRR, NH1 & -1.018 & 1.377 & -0.47 & & \\
\hline LOC_Os12g10740 & $\begin{array}{l}\text { Signalling: } \\
\text { Receptor kinases }\end{array}$ & $\begin{array}{l}\text { leucine-rich } \\
\text { repeat family } \\
\text { protein }\end{array}$ & NRR, Xa21 & -1.137 & 0.384 & 1.261 & 0.895 & -0.62 \\
\hline LOC_Os09g20350 & $\begin{array}{l}\text { RNA Regulation of } \\
\text { transcription }\end{array}$ & $\begin{array}{l}\text { ethylene-responsi } \\
\text { ve transcription } \\
\text { factor }\end{array}$ & NRR, Xa21 & -0.685 & -0.14 & 1.089 & 0.057 & 0.047 \\
\hline LOC_Os05g46020 & $\begin{array}{l}\text { RNA Regulation of } \\
\text { transcription }\end{array}$ & WRKY7 & NRR, NH1 & -0.765 & 0.866 & 0.015 & 2.482 & 1.146 \\
\hline LOC_Os09g25060 & $\begin{array}{l}\text { RNA Regulation of } \\
\text { transcription }\end{array}$ & WRKY76 & $\begin{array}{l}\text { NRR, NH1, } \\
\text { Xa21 }\end{array}$ & -0.982 & 1.784 & 0.68 & 4.089 & 0.357 \\
\hline LOC_Os09g25070 & $\begin{array}{l}\text { RNA Regulation of } \\
\text { transcription }\end{array}$ & WRKY62 & $\begin{array}{l}\text { NRR, NH1, } \\
\text { Xa21 }\end{array}$ & -1.172 & 1.136 & 1.356 & 5.449 & 0.267 \\
\hline LOC_Os11g02530 & $\begin{array}{l}\text { RNA Regulation of } \\
\text { transcription }\end{array}$ & WRKY40 & NH1, Xa21 & -0.215 & 2.101 & 0.735 & 2.091 & 2.903 \\
\hline LOC_Os11g02540 & $\begin{array}{l}\text { RNA Regulation of } \\
\text { transcription }\end{array}$ & WRKY50 & $\begin{array}{l}\text { NRR, NH1, } \\
\text { Xa21 }\end{array}$ & -0.697 & 2.434 & 0.938 & & \\
\hline LOC_Os12g02450 & $\begin{array}{l}\text { RNA Regulation of } \\
\text { transcription }\end{array}$ & WRKY64 & NH1, Xa21 & -0.095 & 2.125 & 0.896 & 2.504 & 2.868 \\
\hline LOC_Os12g02470 & $\begin{array}{l}\text { RNA Regulation of } \\
\text { transcription }\end{array}$ & WRKY65 & NH1, Xa21 & -0.329 & 2.499 & 0.981 & & \\
\hline LOC_Os03g 18850 & $\begin{array}{l}\text { Stress Biotic: PR } \\
\text { protein }\end{array}$ & $\begin{array}{l}\text { pathogenesis-relat } \\
\text { ed Bet v I }\end{array}$ & NH1, Xa21 & 0.66 & 1.05 & 1.11 & 0.43 & -4.09 \\
\hline LOC_Os12g36830 & $\begin{array}{l}\text { Stress Biotic: PR } \\
\text { protein }\end{array}$ & $\begin{array}{l}\text { pathogenesis-relat } \\
\text { ed Bet v I }\end{array}$ & NH1, Xa21 & -0.33 & 1.62 & 1.67 & 1.65 & 1.48 \\
\hline
\end{tabular}




\begin{tabular}{|c|c|c|c|c|c|c|c|c|}
\hline LOC_Os12g36860 & $\begin{array}{l}\text { Stress Biotic: PR } \\
\text { protein }\end{array}$ & $\begin{array}{l}\text { pathogenesis-relat } \\
\text { ed Bet v I }\end{array}$ & NH1, Xa21 & -0.21 & 1.41 & 0.6 & 1.95 & 2.18 \\
\hline LOC_Os12g36880 & $\begin{array}{l}\text { Stress Biotic: PR } \\
\text { protein }\end{array}$ & $\begin{array}{l}\text { pathogenesis-relat } \\
\text { ed Bet v I }\end{array}$ & $\begin{array}{l}\text { NRR, NH1, } \\
\text { Xa21 }\end{array}$ & -0.64 & & 1.57 & 2.08 & 4.23 \\
\hline LOC_Os11g37950 & $\begin{array}{l}\text { Stress Biotic: PR } \\
\text { protein }\end{array}$ & WIP3 & NH1, Xa21 & -0.401 & 0.89 & 1.718 & 0.568 & 3.543 \\
\hline LOC_Os11g37960 & $\begin{array}{l}\text { Stress Biotic: PR } \\
\text { protein }\end{array}$ & WIP4 & NH1, Xa21 & 0.286 & 0.69 & 0.867 & 0.143 & 0.367 \\
\hline LOC_Os12g43380 & $\begin{array}{l}\text { Stress Biotic: PR } \\
\text { protein }\end{array}$ & thaumatin & NH1, Xa21 & -0.418 & 2.357 & 0.71 & 1.26 & 3.374 \\
\hline LOC_Os01g71350 & Misc: PR protein & $\begin{array}{l}\text { glycosyl } \\
\text { hydrolases family } \\
17\end{array}$ & NH1, Xa21 & 0.5 & 0.652 & 1.205 & 0.594 & 1.643 \\
\hline & & glycosyl & & & & & & \\
\hline LOC_Os05g 31140 & Misc: PR protein & $\begin{array}{l}\text { hydrolases family } \\
17\end{array}$ & NRR, Xa21 & -0.788 & -0.75 & 1.859 & 0.322 & 1.236 \\
\hline LOC_Os07g35560 & Misc: PR protein & $\begin{array}{l}\text { glucan } \\
\text { endo-1,3-beta-glu } \\
\text { cosidase } \\
\text { precursor }\end{array}$ & NRR, Xa21 & -1.219 & 0.426 & 1.392 & 1.298 & 0.991 \\
\hline LOC_Os03g22420 & $\begin{array}{l}\text { Secondary } \\
\text { Metabolism }\end{array}$ & $\begin{array}{l}\text { AAA-type } \\
\text { ATPase family } \\
\text { protein }\end{array}$ & NH1, Xa21 & -0.443 & 0.668 & 1.087 & -0.02 & 0.284 \\
\hline LOC_Os05g05940 & $\begin{array}{l}\text { Secondary } \\
\text { Metabolism }\end{array}$ & $\begin{array}{l}\text { stress-related } \\
\text { protein }\end{array}$ & NRR, Xa21 & -0.94 & -0.06 & 1.064 & 0.151 & 0.287 \\
\hline LOC_Os05g 19910 & $\begin{array}{l}\text { Secondary } \\
\text { Metabolism }\end{array}$ & $\begin{array}{l}\text { transferase family } \\
\text { protein }\end{array}$ & NH1, Xa21 & -0.198 & 1.207 & 0.853 & 0.087 & -0.73 \\
\hline LOC_Os01g01710 & $\begin{array}{l}\text { Secondary } \\
\text { Metabolism }\end{array}$ & $\begin{array}{l}\text { 1-deoxy-D-xylulo } \\
\text { se 5-phosphate } \\
\text { reductoisomerase }\end{array}$ & NRR, Xa21 & -0.733 & -0.22 & 1.159 & & \\
\hline LOC_Os02g39160 & $\begin{array}{l}\text { Secondary } \\
\text { Metabolism }\end{array}$ & $\begin{array}{l}\text { hydroxymethylbu } \\
\text { tenyl } \\
\text { 4-diphosphate } \\
\text { synthase }\end{array}$ & NRR, Xa21 & -0.619 & 0.434 & 1.653 & -0.14 & 0.769 \\
\hline LOC_Os02g36140 & $\begin{array}{l}\text { Secondary } \\
\text { Metabolism }\end{array}$ & terpene synthase & NH1, Xa21 & -0.203 & 1.102 & 0.622 & 0.529 & 2.143 \\
\hline LOC_Os04g27340 & $\begin{array}{l}\text { Secondary } \\
\text { Metabolism }\end{array}$ & terpene synthase & NH1, Xa21 & -0.208 & 1.485 & 0.967 & & \\
\hline LOC_Os08g04500 & $\begin{array}{l}\text { Secondary } \\
\text { Metabolism }\end{array}$ & terpene synthase & NH1, Xa21 & -0.264 & 1.487 & 1.611 & 0.829 & -0.78 \\
\hline LOC_Os08g07080 & $\begin{array}{l}\text { Secondary } \\
\text { Metabolism }\end{array}$ & terpene synthase & $\begin{array}{l}\text { NRR, NH1, } \\
\text { Xa21 }\end{array}$ & -1.027 & 3.702 & 3.053 & 1.262 & 0.144 \\
\hline LOC_Os04g15920 & $\begin{array}{l}\text { Secondary } \\
\text { Metabolism }\end{array}$ & dehydrogenase & NH1, Xa21 & -0.173 & 1.197 & 0.662 & 0.505 & 2.103 \\
\hline LOC_Os02g08100 & $\begin{array}{l}\text { Secondary } \\
\text { Metabolism }\end{array}$ & $\begin{array}{l}\text { AMP-binding } \\
\text { domain } \\
\text { containing } \\
\text { protein }\end{array}$ & NH1, Xa21 & -0.036 & 0.858 & 0.697 & -0.23 & 0.368 \\
\hline
\end{tabular}




\begin{tabular}{|c|c|c|c|c|c|c|c|c|}
\hline LOC_Os04g53810 & $\begin{array}{l}\text { Secondary } \\
\text { Metabolism }\end{array}$ & $\begin{array}{l}\text { leucoanthocyanid } \\
\text { in reductase }\end{array}$ & NRR, Xa21 & -0.881 & 0.054 & .585 & 1.545 & 0.797 \\
\hline LOC_Os01g13590 & $\begin{array}{l}\text { Secondary } \\
\text { Metabolism }\end{array}$ & $\begin{array}{l}\text { isoflavone } \\
\text { reductase } \\
\text { homolog IRL }\end{array}$ & NH1, Xa21 & 0.829 & 1.694 & 1.035 & & \\
\hline & & vacuolar-processi & & & & & & \\
\hline LOC_Os01g37910 & Protein Degradation & $\begin{array}{l}\text { ng enzyme } \\
\text { precursor }\end{array}$ & NRR, Xa21 & -1.349 & -0.5 & 1.99 & 0.193 & -1.02 \\
\hline LOC_Os01g58580 & Protein Degradation & $\begin{array}{l}\text { ICE-like protease } \\
\text { p20 domain } \\
\text { containing } \\
\text { protein }\end{array}$ & NRR, Xa21 & -0.822 & -0.41 & 1.179 & 0.003 & 0.563 \\
\hline LOC_Os11g24540 & Protein Degradation & $\begin{array}{l}\text { signal peptide } \\
\text { peptidase-like 2B }\end{array}$ & NRR, Xa21 & -0.66 & -0.16 & 0.972 & -0.14 & 0.45 \\
\hline LOC_Os03g13970 & Protein Degradation & $\begin{array}{l}26 \mathrm{~S} \text { proteasome } \\
\text { non-ATPase } \\
\text { regulatory } \\
\text { subunit } 4\end{array}$ & NRR, Xa21 & -0.633 & -0.42 & 1.06 & -0.14 & 0.229 \\
\hline LOC_Os04g57300 & Protein Degradation & $\begin{array}{l}\text { phosphatidylinosi } \\
\text { tol 3- and } \\
\text { 4-kinase family } \\
\text { protein }\end{array}$ & NRR, Xa21 & -0.763 & -0.67 & 1.322 & 0.016 & -0.17 \\
\hline LOC_Os01g48930 & Protein Degradation & $\begin{array}{l}\text { splicing } \\
\text { factor-related }\end{array}$ & NRR, Xa21 & -0.625 & -0.63 & 1.411 & 0.285 & -0.83 \\
\hline LOC_Os02g06640 & Protein Degradation & $\begin{array}{l}\text { ubiquitin family } \\
\text { protein }\end{array}$ & $\begin{array}{l}\text { NRR, NH1, } \\
\text { Xa21 }\end{array}$ & -1.064 & 0.694 & 0.61 & -0.03 & 0.854 \\
\hline LOC_Os02g05710 & Protein Degradation & $\begin{array}{l}\text { expressed protein } \\
\text { zinc finger, } \\
\mathrm{C} 3 \mathrm{HC} 4 \text { type }\end{array}$ & NRR, Xa21 & -0.822 & -0.46 & 1.091 & -0.1 & 0.469 \\
\hline LOC_Os04g51400 & Protein Degradation & $\begin{array}{l}\text { domain } \\
\text { containing } \\
\text { protein }\end{array}$ & NRR, Xa21 & -0.918 & -0.73 & 1.3 & 0.144 & -1.39 \\
\hline LOC_Os06g03580 & Protein Degradation & $\begin{array}{l}\text { zinc RING finger } \\
\text { protein }\end{array}$ & NRR, NH1 & -0.678 & 0.916 & -0.45 & 1.465 & -0.12 \\
\hline & & $\begin{array}{l}\text { zinc finger, } \\
\text { C3HC4 type }\end{array}$ & & & & & & \\
\hline LOC_Os11g36430 & Protein Degradation & $\begin{array}{l}\text { domain } \\
\text { containing } \\
\text { protein }\end{array}$ & NRR, Xa21 & -0.874 & -0.43 & 0.982 & 0.031 & -0.24 \\
\hline LOC_Os02g10700 & Protein Degradation & OsFBL7 & NRR, Xa21 & -1.001 & 0.262 & 1.108 & 1.087 & -0.42 \\
\hline LOC_Os06g40360 & Protein Degradation & OsFBL30 & NRR, Xa21 & -0.945 & 0.442 & 0.789 & 0.491 & -0.49 \\
\hline LOC_Os05g33610 & Protein Degradation & expressed protein & NRR, Xa21 & -0.677 & -0.56 & 1.021 & -0.29 & 0.19 \\
\hline LOC_Os02g57410 & Protein Degradation & $\begin{array}{l}\text { OTU-like } \\
\text { cysteine protease } \\
\text { family protein }\end{array}$ & NRR, Xa21 & -0.81 & -0.43 & 1.278 & -0.12 & 0.141 \\
\hline LOC_Os01g64840 & Protein Degradation & $\begin{array}{l}\text { aspartic } \\
\text { proteinase } \\
\text { nepenthesin-1 } \\
\text { precursor }\end{array}$ & NH1, Xa21 & 0.637 & 1.506 & 0.868 & -0.03 & 0.021 \\
\hline
\end{tabular}




\begin{tabular}{|c|c|c|c|c|c|c|c|c|}
\hline LOC_Os05g04630 & Protein Degradation & $\begin{array}{l}\text { retrotransposon } \\
\text { protein } \\
\text { eukaryotic } \\
\text { aspartyl protease }\end{array}$ & NRR, Xa21 & -0.665 & -0.31 & 1.266 & 0.009 & 0.377 \\
\hline LOC_Os09g37012 & Protein Degradation & $\begin{array}{l}\text { domain } \\
\text { containing } \\
\text { protein }\end{array}$ & NRR, Xa21 & -0.647 & -0.37 & 1.507 & 0.042 & -0.09 \\
\hline LOC_Os09g36300 & Protein Degradation & $\begin{array}{l}\text { OsLonP4 - } \\
\text { Putative Lon } \\
\text { protease } \\
\text { homologue }\end{array}$ & NRR, Xa21 & -0.933 & -0.21 & 0.823 & 0.418 & 0.057 \\
\hline & & AAA-type & & & & & & \\
\hline LOC_Os03g22420 & Protein Degradation & $\begin{array}{l}\text { ATPase family } \\
\text { protein }\end{array}$ & NH1, Xa21 & -0.443 & 0.668 & 1.087 & -0.02 & 0.284 \\
\hline LOC_Os03g58790 & Protein Degradation & ATPase & $\begin{array}{l}\text { NRR, NH1, } \\
\text { Xa21 }\end{array}$ & -0.665 & 0.748 & 1.072 & 2.85 & 0.993 \\
\hline LOC_Os07g29290 & $\begin{array}{l}\text { Cellwall } \\
\text { Modification }\end{array}$ & $\begin{array}{l}\text { expansin } \\
\text { precursor }\end{array}$ & NH1, Xa21 & -0.166 & 0.663 & 0.914 & -0.55 & 1.402 \\
\hline LOC_Os01g01160 & Stress Abiotic & $\begin{array}{l}\text { heat shock } \\
\text { protein DnaJ }\end{array}$ & NH1, Xa21 & 0.508 & 1.146 & 0.783 & & \\
\hline LOC_Os03g31300 & Stress Abiotic & $\begin{array}{l}\text { chaperone protein } \\
\text { clpB } 1\end{array}$ & NRR, Xa21 & -0.695 & 0.16 & 1.389 & -0.23 & -0.97 \\
\hline
\end{tabular}

Table S5. Primer sequences of genes used for real-time RT-PCR analysis

\begin{tabular}{|c|c|c|}
\hline Locus ID & Forward primer & Reverse primer \\
\hline Os09g20350 & TGCAGCTATAGATCTGTCAG & TGGATGTAGTGCATCTGGG \\
\hline Os05g46020 & AAGAAGTCCGTCAAGAACAG & GCGTAGTACACCGTGCTG \\
\hline Os09g25060 & ACGCTCGACCTCACCAAGAA & AACTTGGGGTCGCTGGTGAG \\
\hline Os09g25070 & TTCCGCTGCGCATTCGCG & TGCTGGCTCGTAGTGCAG \\
\hline Os11g02530 & GCCAACAGCTACAATGGC & TTCCGCAGCCTGCAGATC \\
\hline Os1 1 g02540 & CATGCCGACAGATGATCGC & CAAGGAGCAAATCGTCCATC \\
\hline Os $12 g 02450$ & GCCAACAGCTACAATGGC & CGCAGCCTGCAGCTCGCT \\
\hline Os $12 g 02470$ & GACGACCACCTCTGGTTCT & CAAATGGGTGATGTTAGCGC \\
\hline Os03g18850 & GTCAGGCAGTTCAACTTCAC & CGGCTCCACCTTGATGTG \\
\hline Os $12 g 36830$ & CTGTCACCACCATGAAGCTC & GCCAAGCAAGAGCCGGCA \\
\hline Os $12 g 36860$ & CAATGCAGCACGCGTGCTA & GAAGTAGCCGTCGACCATC \\
\hline Os $12 g 36880$ & CGCCGCAAGTCATGTCCTA & ATAGTAGCCATCCACGATG \\
\hline Os1 1 g37950 & GTCAGAAGTATGGCTGGAC & TGTCCCAGTCCAGGTCAAG \\
\hline Os1lg37960 & GAAGTATGGATGGACCGCCT & AGCCTTGACCGTCGCTGT \\
\hline Os12g43380 & AGCATCTCGATCCTACCACA & ACCGGTTGGTGATGGTGAA \\
\hline Os01g71350 & CGTACAACCAGAAGCTTATC & TAATTTTGTAGGACGGCGAC \\
\hline Os05g31140 & TCTACAACCAGAACCTCATC & AGAAGCTGATGGGGTAGAC \\
\hline Os07g35560 & TATTGTCTACAAGCCTTCAC & CTTGGTGTCAGGGTCAAAGC \\
\hline Os01g22490(OsUbi5) & GCACAAGCACAAGAAGGTGA & GCCTGCTGGTTGTAGACGTA \\
\hline Os03g08010(OseEF1) & TCAAGTTTGCTGAGCTGGTG & TTTGCCTCATGTCCCGCAC \\
\hline
\end{tabular}


Table S6. Summary of functionally characterized genes in our candidate genes

\begin{tabular}{|c|c|c|c|c|c|}
\hline Locus_ID & Gene name & $\begin{array}{l}\text { Abbreviatio } \\
\text { n of gene } \\
\text { name }\end{array}$ & $\begin{array}{l}\text { Category of } \\
\text { function }\end{array}$ & Description of gene function & $\begin{array}{l}\text { References } \\
\text { (DOI) }\end{array}$ \\
\hline LOC_Os01g09800 & $\begin{array}{l}\text { NONEXPRESSO } \\
\text { R OF } \\
\text { PATHOGENESIS } \\
\text {-RELATED } \\
\text { GENES1 }\end{array}$ & OsNPR1 & $\begin{array}{l}\text { Bacterial blight } \\
\text { resistance }\end{array}$ & $\begin{array}{l}\text { Enhanced bacterial blight } \\
\text { resistance and herbivore } \\
\text { susceptibility. }\end{array}$ & $\begin{array}{l}10.1111 / \mathrm{j} .1467- \\
7652.2007 .0024 \\
3 . x\end{array}$ \\
\hline LOC_Os09g25070 & OsWRKY62 & OsWRKY62 & $\begin{array}{l}\text { Bacterial blight } \\
\text { resistance }\end{array}$ & $\begin{array}{l}\text { Resistance to Xanthomonas } \\
\text { oryzae pv. oryzae. }\end{array}$ & $\begin{array}{l}10.1093 / \mathrm{mp} / \mathrm{ssn} \\
024\end{array}$ \\
\hline LOC_Os02g08440 & OsWRKY71 & OsWRKY71 & $\begin{array}{l}\text { Bacterial blight } \\
\text { resistance }\end{array}$ & $\begin{array}{l}\text { Resistance to Xanthomonas } \\
\text { oryzae pv. oryzae. }\end{array}$ & $\begin{array}{l}\text { 10.1016/j.jplph. } \\
\text { 2006.07.006 }\end{array}$ \\
\hline LOC_Os09g25060 & OsWRKY76 & OsWRKY76 & $\begin{array}{l}\text { Bacterial blight } \\
\text { resistance }\end{array}$ & $\begin{array}{l}\text { Resistance to Xanthomonas } \\
\text { oryzae pv. oryzae. }\end{array}$ & $\begin{array}{l}10.1007 / \mathrm{s} 12284- \\
010-9039-6\end{array}$ \\
\hline LOC_Os10g41980 & RALFL26 & Rirlb & Blast resistance & $\begin{array}{l}\text { Resistance to Magnaporthe } \\
\text { grisea. }\end{array}$ & $\begin{array}{l}\text { 10.1023/A:1006 } \\
423232753\end{array}$ \\
\hline LOC_Os06g03580 & $\begin{array}{l}\text { zinc RING finger } \\
\text { protein }\end{array}$ & osbbil & Blast resistance & $\begin{array}{l}\text { Resistance to Magnaporthe } \\
\text { oryzae. Cell wall defense. }\end{array}$ & $\begin{array}{l}10.1038 / \mathrm{cr} .2011 \\
.4\end{array}$ \\
\hline LOC_Os05g31140 & beta-glucanase 1 & Gns1 & Blast resistance & $\begin{array}{l}\text { Resistance to Magnaporthe } \\
\text { grisea. Lesion mimic. }\end{array}$ & $\begin{array}{l}\text { 10.1023/A: } 1020 \\
714426540\end{array}$ \\
\hline LOC_Os03g51030 & phytochromeA & phyA & Blast resistance & $\begin{array}{l}\text { Resistance to Magnaporthe } \\
\text { grisea. }\end{array}$ & $\begin{array}{l}10.1093 / \mathrm{mp} / \mathrm{ssr} 0 \\
05\end{array}$ \\
\hline LOC_Os03g20380 & $\begin{array}{l}\text { calcineurin B-like } \\
\text { protein-interacting } \\
\text { protein kinase } 03\end{array}$ & OsCIPK03 & Cold tolerance & Cold tolerance. & $\begin{array}{l}10.1104 / \text { pp.107. } \\
101295\end{array}$ \\
\hline LOC_Os03g12290 & $\begin{array}{l}\text { glutamine } \\
\text { synthetase 1;2 }\end{array}$ & GS1;2 & Cold tolerance & $\begin{array}{l}\text { "Leaf nitrogen conten. Cold, } \\
\text { drought and salinity tolerance. } \\
\text { Basta selection resistance." }\end{array}$ & $\begin{array}{l}10.1007 / \mathrm{s} 00299- \\
008-0665-\mathrm{z}\end{array}$ \\
\hline LOC_Os03g24040 & $\begin{array}{l}\text { drought-induced } \\
\text { SINA protein } 1\end{array}$ & OsDIS1 & Drought tolerance & Drought tolerance. & $\begin{array}{l}10.1104 / \text { pp.111. } \\
180893\end{array}$ \\
\hline LOC_Os07g45570 & BL-enhanced 2 & OsBLE2 & Culm leaf & $\begin{array}{l}\text { Dwarfism. Leaf angle. } \\
\text { Brassinosteroid sensitivity. }\end{array}$ & $\begin{array}{l}\text { 10.1023/A: } 1025 \\
001304994\end{array}$ \\
\hline LOC_Os02g09490 & $\begin{array}{l}\text { GOLDHULLAN } \\
\text { DINTERNODE2 }\end{array}$ & gh2 & Culm leaf & $\begin{array}{l}\text { Lignin content. Seed color. } \\
\text { Internode color. }\end{array}$ & $\begin{array}{l}10.1104 / \mathrm{pp} .105 . \\
073007\end{array}$ \\
\hline LOC_Os02g08100 & $\begin{array}{l}\text { 4-Coumarate:coen } \\
\text { zyme A ligase }\end{array}$ & Os4CL3 & Dwarf & $\begin{array}{l}\text { Lignin content. Dwarfism. Culm } \\
\text { length. Anther development. }\end{array}$ & $\begin{array}{l}10.1104 / p p .111 \\
178301\end{array}$ \\
\hline LOC_Os08g06480 & $\begin{array}{l}\text { Lissencephaly } \\
\text { type-1-like } 1\end{array}$ & OsLIS-L1 & Dwarf & $\begin{array}{l}\text { Dwarfism. Elongation of } \\
\text { uppermost internode. Pollen } \\
\text { development. }\end{array}$ & $\begin{array}{l}10.1007 / \mathrm{s} 00425- \\
011-1532-7\end{array}$ \\
\hline LOC_Os01g22010 & $\begin{array}{l}\text { S-Adenosyl-1-met } \\
\text { hionine } \\
\text { synthetase } 2\end{array}$ & OsSAMS2 & Dwarf & $\begin{array}{l}\text { Dwarfism. Fertility. Germination } \\
\text { rate. Flowering time. }\end{array}$ & $\begin{array}{l}\text { 10.1016/j.jplph. } \\
2011.05 .020\end{array}$ \\
\hline LOC_Os01g48680 & $\begin{array}{l}\text { two-pore channel } \\
1\end{array}$ & Ostpc1 & Dwarf & Sensitivity to $\mathrm{Ca}+$ in growth rate. & $\begin{array}{l}10.1093 / \mathrm{pcp} / \mathrm{pch} \\
082\end{array}$ \\
\hline LOC_Os01g55540 & $\begin{array}{l}\text { Aspartate } \\
\text { aminotransferase } 2\end{array}$ & OsAAT2 & Eating quality & $\begin{array}{l}\text { Seed amino acid and protein } \\
\text { content. }\end{array}$ & $\begin{array}{l}10.1007 / \mathrm{s} 00122- \\
009-0988-3\end{array}$ \\
\hline LOC_Os08g32870 & $\begin{array}{l}\text { betaine aldehyde } \\
\text { dehydrogenase } 2\end{array}$ & Badh2 & Eating quality & $\begin{array}{l}\text { Fragrance rice. } \\
\text { 2-acetyl-1-pyrroline }\end{array}$ & $\begin{array}{l}10.1105 / \text { tpc. } 108 . \\
058917\end{array}$ \\
\hline
\end{tabular}




\begin{tabular}{|c|c|c|c|c|c|}
\hline & & & & biosynthesis. & \\
\hline LOC_Os05g33570 & $\begin{array}{l}\text { floury } \\
\text { endosperm-4 }\end{array}$ & flo4 & Eating quality & Seed protein and lipid content. & $\begin{array}{l}10.1111 / \mathrm{j} .1365- \\
313 X .2005 .0242 \\
3 . x\end{array}$ \\
\hline LOC_Os09g29404 & isoamylase 3 & isa3 & Eating quality & Seed starch content. & $\begin{array}{l}10.1093 / \mathrm{pcp} / \mathrm{pcr} \\
058\end{array}$ \\
\hline LOC_Os03g09250 & $\begin{array}{l}\text { rice myo -inositol } \\
\text { 3-phosphate } \\
\text { synthase } 1\end{array}$ & RINO1 & Eating quality & Seed phytic acid content. & $\begin{array}{l}10.1093 / \mathrm{pcp} / \mathrm{pcp} \\
071\end{array}$ \\
\hline LOC_Os02g43370 & $\begin{array}{l}\text { yellow stripe } 1 \text { like } \\
2\end{array}$ & OsYSL2 & Eating quality & $\begin{array}{l}\mathrm{Fe} \text { and } \mathrm{Mn} \text { translocation from } \\
\text { root to shoot and endosperm. }\end{array}$ & $\begin{array}{l}\text { 10.1111/j.1365- } \\
313 X .2010 .0415 \\
8 . x\end{array}$ \\
\hline LOC_Os09g06464 & $\begin{array}{l}\text { CONSTANS-LIK } \\
\text { E } 3\end{array}$ & OsCO3 & Flowering & $\begin{array}{l}\text { Flowering time under short day } \\
\text { condition. }\end{array}$ & $\begin{array}{l}10.1007 / \mathrm{s} 00425- \\
008-0742-0\end{array}$ \\
\hline LOC_Os01g15900 & $\begin{array}{l}\text { rice Dof daily } \\
\text { fluctuations } 1\end{array}$ & Rdd1 & Flowering & $\begin{array}{l}\text { Grain length and width. } \\
1000 \text {-grain weight. Flowering } \\
\text { time. }\end{array}$ & $\begin{array}{l}10.1111 / \mathrm{j} .1365- \\
3040.2009 .0195 \\
4 . x\end{array}$ \\
\hline LOC_Os03g13970 & $\begin{array}{l}26 \mathrm{~S} \text { proteasome } \\
\text { non-ATPase } \\
\text { regulatory subunit } \\
4\end{array}$ & RPN10 & $\begin{array}{l}\text { Other soil stress } \\
\text { tolerance }\end{array}$ & Canavanine resistance. & $\begin{array}{l}\text { 10.5511/plantbi } \\
\text { otechnology. } 21 \text {. } \\
233\end{array}$ \\
\hline LOC_Os01g72370 & bHLH & OsIRO2 & $\begin{array}{l}\text { Other soil stress } \\
\text { tolerance }\end{array}$ & $\begin{array}{l}\text { Fe uptake under Fe-deficient } \\
\text { conditions. Secretion of } \\
\text { mugineic acid family } \\
\text { phytosiderophores. }\end{array}$ & $\begin{array}{l}\text { 10.1111/j.1365- } \\
313 X .2007 .0314 \\
9 . x\end{array}$ \\
\hline LOC_Os07g12890 & $\begin{array}{l}\text { metal cation } \\
\text { transporter }\end{array}$ & OsZIP8 & $\begin{array}{l}\text { Other soil stress } \\
\text { tolerance }\end{array}$ & Zn uptake and translocation. & $\begin{array}{l}10.1007 / \mathrm{s} 10059- \\
010-0069-0\end{array}$ \\
\hline LOC_Os05g45410 & $\begin{array}{l}\text { Heat shock } \\
\text { transcription } \\
\text { factor A4a }\end{array}$ & OsHsfA4a & $\begin{array}{l}\text { Other soil stress } \\
\text { tolerance }\end{array}$ & Cadmium tolerance. & $\begin{array}{l}10.1105 / \text { tpc. } 109 . \\
066902\end{array}$ \\
\hline LOC_Os05g48390 & $\begin{array}{l}\text { LEAF TIP } \\
\text { NECROSIS } 1\end{array}$ & $\operatorname{ltn} 1$ & $\begin{array}{l}\text { Other soil stress } \\
\text { tolerance }\end{array}$ & $\begin{array}{l}\text { Phosphate uptake and } \\
\text { translocation. }\end{array}$ & $\begin{array}{l}10.1104 / p p .110 . \\
170209\end{array}$ \\
\hline LOC_Os02g20360 & $\begin{array}{l}\text { Nicotianamine } \\
\text { aminotransferase } 1\end{array}$ & naat1 & $\begin{array}{l}\text { Other soil stress } \\
\text { tolerance }\end{array}$ & Fe acquisition strategy. & $\begin{array}{l}10.1104 / p p .107 . \\
107912\end{array}$ \\
\hline LOC_Os03g05620 & $\begin{array}{l}\text { PHOSPHATE } \\
\text { TRANSPORTER } \\
1\end{array}$ & OsPT1 & $\begin{array}{l}\text { Other soil stress } \\
\text { tolerance }\end{array}$ & $\begin{array}{l}\text { Phosphate starvation tolerance. } \\
\text { Phosphate uptake. }\end{array}$ & $\begin{array}{l}10.1104 / \text { pp. } 112 . \\
196345\end{array}$ \\
\hline LOC_Os06g09370 & $\begin{array}{l}\mathrm{Pi} \\
\text { starvationinduced } \\
\text { transcription } \\
\text { factor } 1\end{array}$ & OsPTF1 & $\begin{array}{l}\text { Other soil stress } \\
\text { tolerance }\end{array}$ & Phosphate starvation tolerance. & $\begin{array}{l}10.1104 / \text { pp. } 105 . \\
063115\end{array}$ \\
\hline LOC_Os06g40120 & $\begin{array}{l}\text { SYG/PHO81/XPR } \\
1 \text { domain } 1\end{array}$ & OsSPX1 & $\begin{array}{l}\text { Other soil stress } \\
\text { tolerance }\end{array}$ & Phosphate homeostasis. & $\begin{array}{l}\text { 10.1111/j.1365- } \\
313 X .2008 .0373 \\
4 . x\end{array}$ \\
\hline LOC_Os03g55240 & cytochrome $\mathrm{P} 450$ & bel & $\begin{array}{l}\text { Other stress } \\
\text { resistance }\end{array}$ & Herbicide resistance. & $\begin{array}{l}10.1007 / \mathrm{s} 11103- \\
006-0058-\mathrm{z}\end{array}$ \\
\hline LOC_Os01g01660 & $\begin{array}{l}\text { isoflavone } \\
\text { reductase-like }\end{array}$ & OsIRL & $\begin{array}{l}\text { Other stress } \\
\text { resistance }\end{array}$ & $\begin{array}{l}\text { Resistance to reactive oxygen } \\
\text { species. }\end{array}$ & $\begin{array}{l}\text { 10.1111/j.1399- } \\
3054.2009 .0129 \\
0 . x\end{array}$ \\
\hline LOC_Os08g03290 & cytosolic GAPDH & OsGAPC3 & Salinity tolerance & Salinity tolerance. & $10.1007 / \mathrm{s} 11240-$ \\
\hline
\end{tabular}




\begin{tabular}{|c|c|c|c|c|c|}
\hline & protein 3 & & & & $011-9950-6$ \\
\hline LOC_Os07g48430 & root hairless 1 & rth1 & Root & Root hair formation. & $\begin{array}{l}10.1270 / \text { jsbbs. } 5 \\
9.13\end{array}$ \\
\hline LOC_Os01g64660 & $\begin{array}{l}\text { cytosolic } \\
\text { fructose-1,6-bisph } \\
\text { osphatase1 }\end{array}$ & oscfbp1 & Source activity & $\begin{array}{l}\text { Photosynthetic sucrose } \\
\text { biosynthesis. Growth retardation. }\end{array}$ & $\begin{array}{l}10.1111 / \mathrm{j} .1365- \\
3040.2008 .0189 \\
0 . x\end{array}$ \\
\hline LOC_Os07g04180 & $\begin{array}{l}\text { amino acid } \\
\text { transporter60 }\end{array}$ & OsAAT60 & Source activity & Carbon content. & $\begin{array}{l}10.1007 / \mathrm{s} 11738- \\
012-0995-\mathrm{x}\end{array}$ \\
\hline LOC_Os10g41780 & $\begin{array}{l}\text { Chlorophyllide a } \\
\text { oxygenase }\end{array}$ & cao & Source activity & Chlorophyll content. & $\begin{array}{l}10.1270 / \text { jsbbs. } 5 \\
5.361\end{array}$ \\
\hline LOC_Os09g36200 & staygreen & sgr & Source activity & $\begin{array}{l}\text { Leaf senescence. Chlorophyll } \\
\text { degradation. }\end{array}$ & $\begin{array}{l}10.1105 / \text { tpc. } 106 . \\
044891\end{array}$ \\
\hline LOC_Os01g01280 & $\begin{array}{l}\text { Thylakoid lumen } \\
\text { protein } 27\end{array}$ & OsTLP27 & Source activity & $\begin{array}{l}\text { Photochemical efficiency. Size } \\
\text { and number of grana. }\end{array}$ & $\begin{array}{l}\text { 10.1016/j.plants } \\
\text { ci. } 2012.06 .006\end{array}$ \\
\hline
\end{tabular}

\section{Copyrights}

Copyright for this article is retained by the author(s), with first publication rights granted to the journal.

This is an open-access article distributed under the terms and conditions of the Creative Commons Attribution license (http://creativecommons.org/licenses/by/3.0/). 